\title{
THE TANNINS
}

HE TAY TRIMBLE

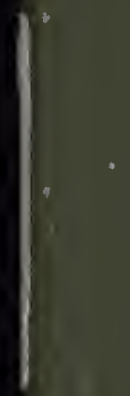




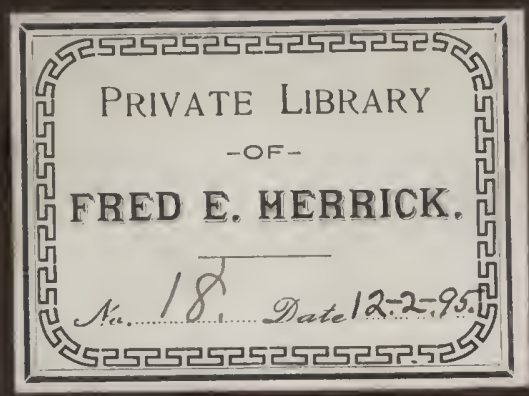





\section{. .11}

$\because \quad \therefore$ 
From the Zibrary of Prof J.M. Maisch. EB. Mronan

F. E. HERRICK. 


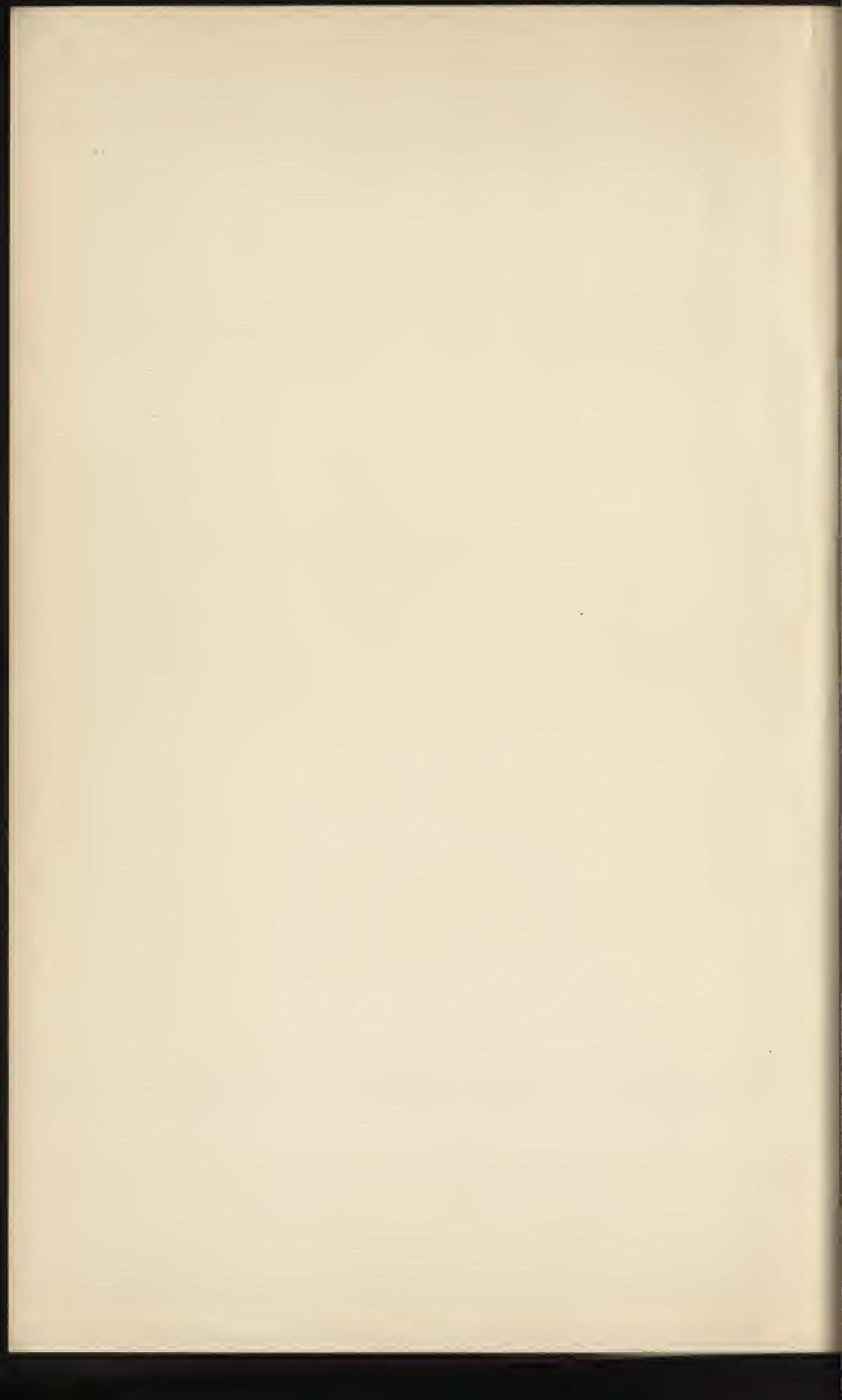




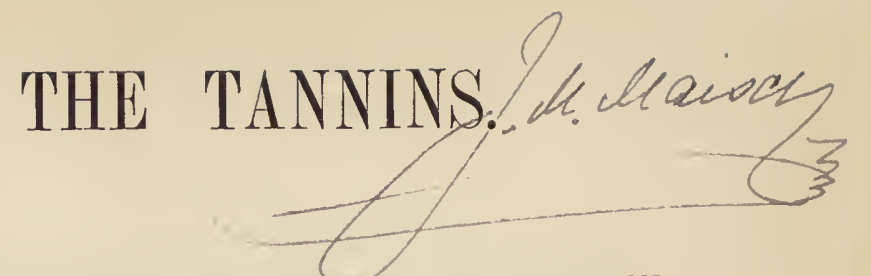

A MONOGRAPH ON THE HISTORY, PREPARATION, PROPERTIES, NETHODS OF ESTIMATION,

AND USES OF THE VEGETABLE ASTRINGENTS,

\begin{abstract}
WITH AN INDEX TO THE LITERATURE OF THE SUBJECT.
\end{abstract}

BY

\title{
HENRY TRIMBLE, Ph.M.,
}

PROFESSOR OF ANALYTICAL CHEMISTRY IN THE PIILADELPHIA COLLEGH OF PHARMACY.

VOLUME I.

P II I L A D E L P H I A :

J. B. LIPPINCOTT COMPANY.

1892. 


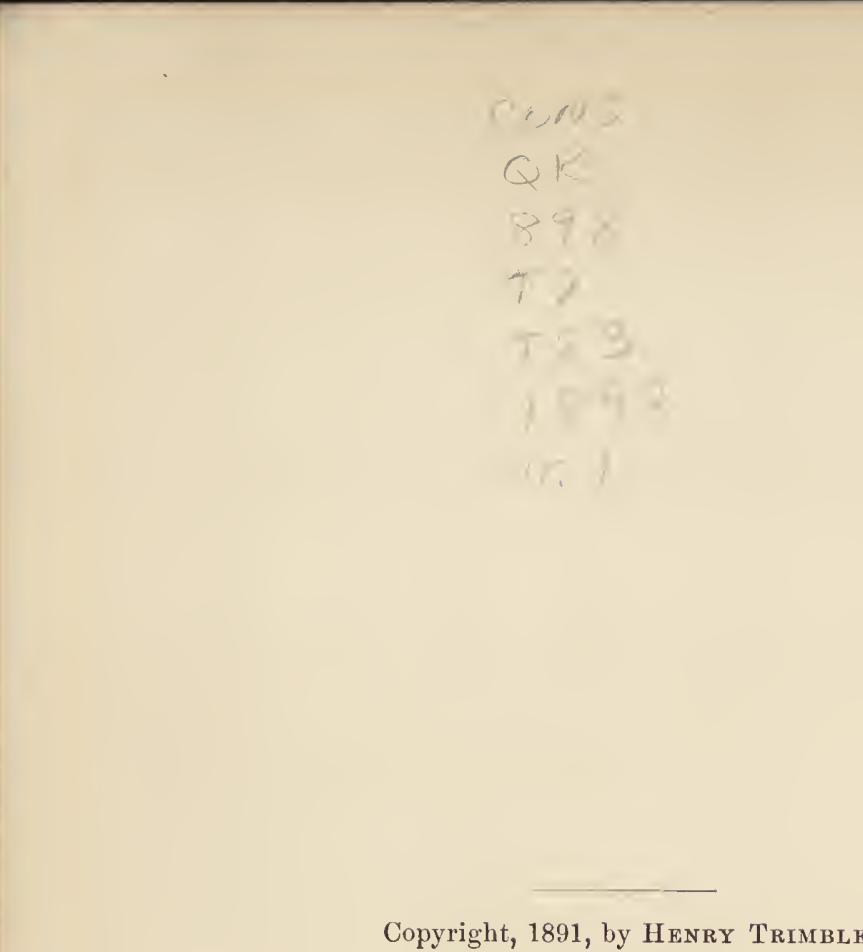

Copyright, 1891, by Henry Trimble.

Printed by J. B. Lippincott Company, Philadelphia. 


\section{PREFACE.}

The title of this monograph might well have been "A Century of Tannin," as just about one hundred years have elapsed since tannin first became recognized as a distinct substance, or class of substances, as we now express it. To emphasize this idea of a class of substances the present title was selected.

About twelve years ago the author commenced to collect a portion of the literature on the subject, especially that referring to the astringent value of certain tannin-bearing materials, with the methods involved in their estimation. He found, however, the task rapidly assuming such formidable proportions that only by beginning with the history and systematically pursuing the subject through its various phases to an ending, with a complete index to the literature, could he hope to reduce the many published inconsistencies and contradictions to a condition that would be available to himself as well as to others.

The taking of notes and references has been persistently carried on, especially during the past fivc years, until it is now thought best to give to the public the work on the gencral subject, with gallotannic acid, and the index to the literature, lcaving for a subsequent volume the remaining individual tannins, with such further additions to the index as it may be found possible to collect.

It has been the constant effort of the author to make 
this volume something more than a mere compilation of others' work, therefore some of his own experience has been incorporated which is here published for the first time, and this will be kept constantly in mind during the further contributions on the subject.

The tannins occupy a part of the border-land in science between botany and chemistry, which fact has added to the bulk of the litcrary index as well as to the difficultics of collecting it.

However, by the aid of the many complete sets of valuable foreign chemical periodicals recently acquired by the library of the Franklin Institute, and also through constant access to the library of the Philadelphia College of Pharmacy, it has been possible to take from the original sources all but about five per cent. of the titles given. Such references as could not be so consulted were taken from the most available source, and, if possible, in the samc language as the original.

It is with the hope that information will be received from others interested in the subject, which will assist in making the index more complete, that it is issued at the present time.

Much valuable assistance has already been received by the author, especially from those having desirable private libraries, for which he hereby tenders his sincere thanks.

Philadelphia, November 13, 1891. 


\title{
CONTENTS.
}

\author{
PART I.
}

General Description of the Tannins..... . . 7

Section X.-The Discovery of the Tannins . . . . 9-16

Section II.-General Characters . . . . . . 17-30

ShCTION III.-The Detection and Estimation of the

Tannins ............ . . 31-51

\section{PART II.}

Gallotannic Acto . . . . . . . . . . . . . . 53

SECTION I.-Sources . . . . . . . . . . 55-64

SECTION II.-History . . . . . . . . . . 65-77

Sectron III.-The Preparation and Purification of

Tannic Acid . . . . . . . . . . . . . . 78-87

Section IV.-The Properties of Tannic Acid . . . 88-93

Section V.-The Composition and Constitution of

Tannic Acid . . . . . . . . . . . . . . . 94-99

AN Index to the Literature of the Tannins . . 101

INDEX OF AUTHORS . . . . . . . . . 103-108

INDex of Titles with Authors AND Sources 109-162

List of Books containing Notable Chapters

on The Tannins ............... 163-165 


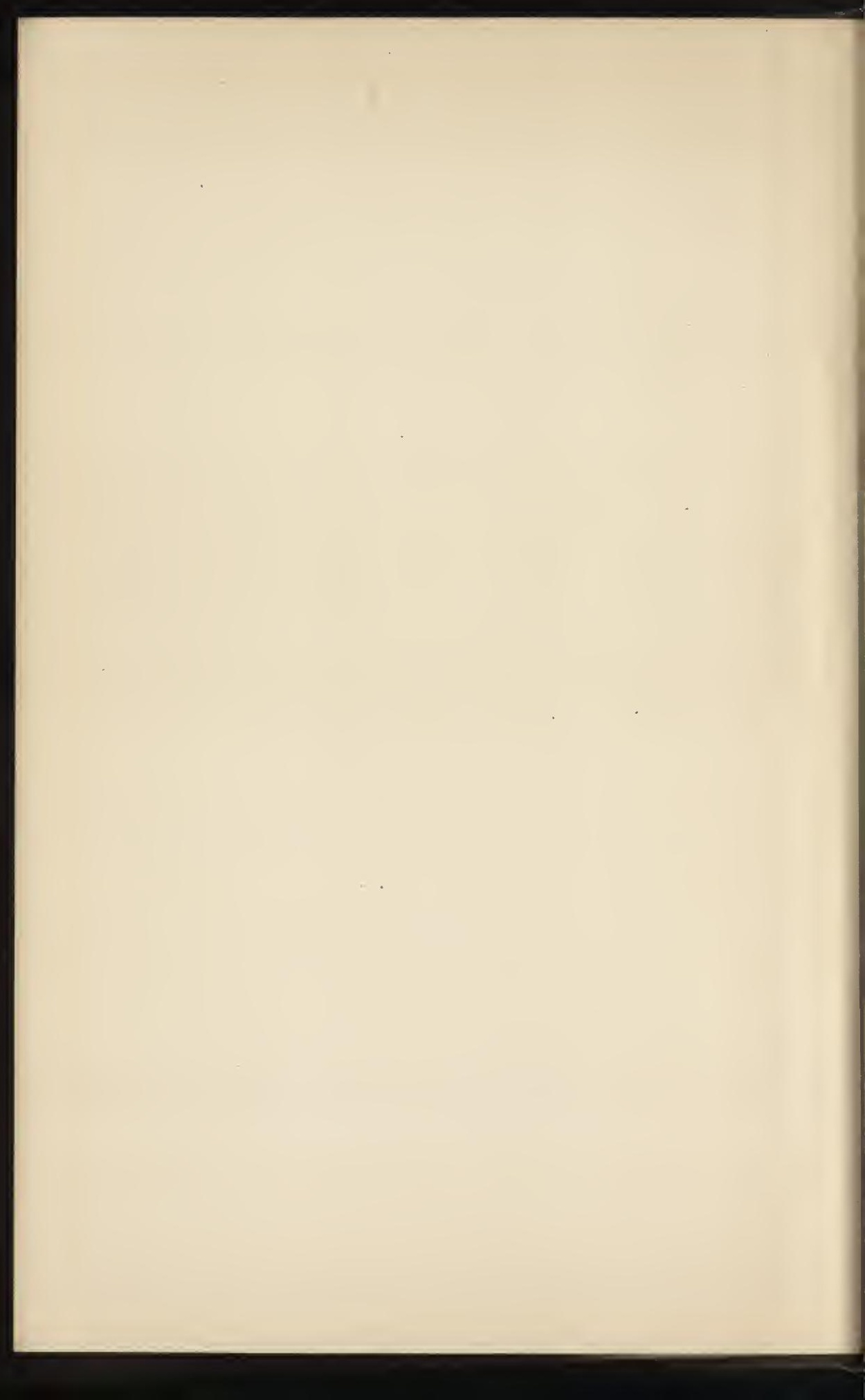


PART I.

GENERAL. 


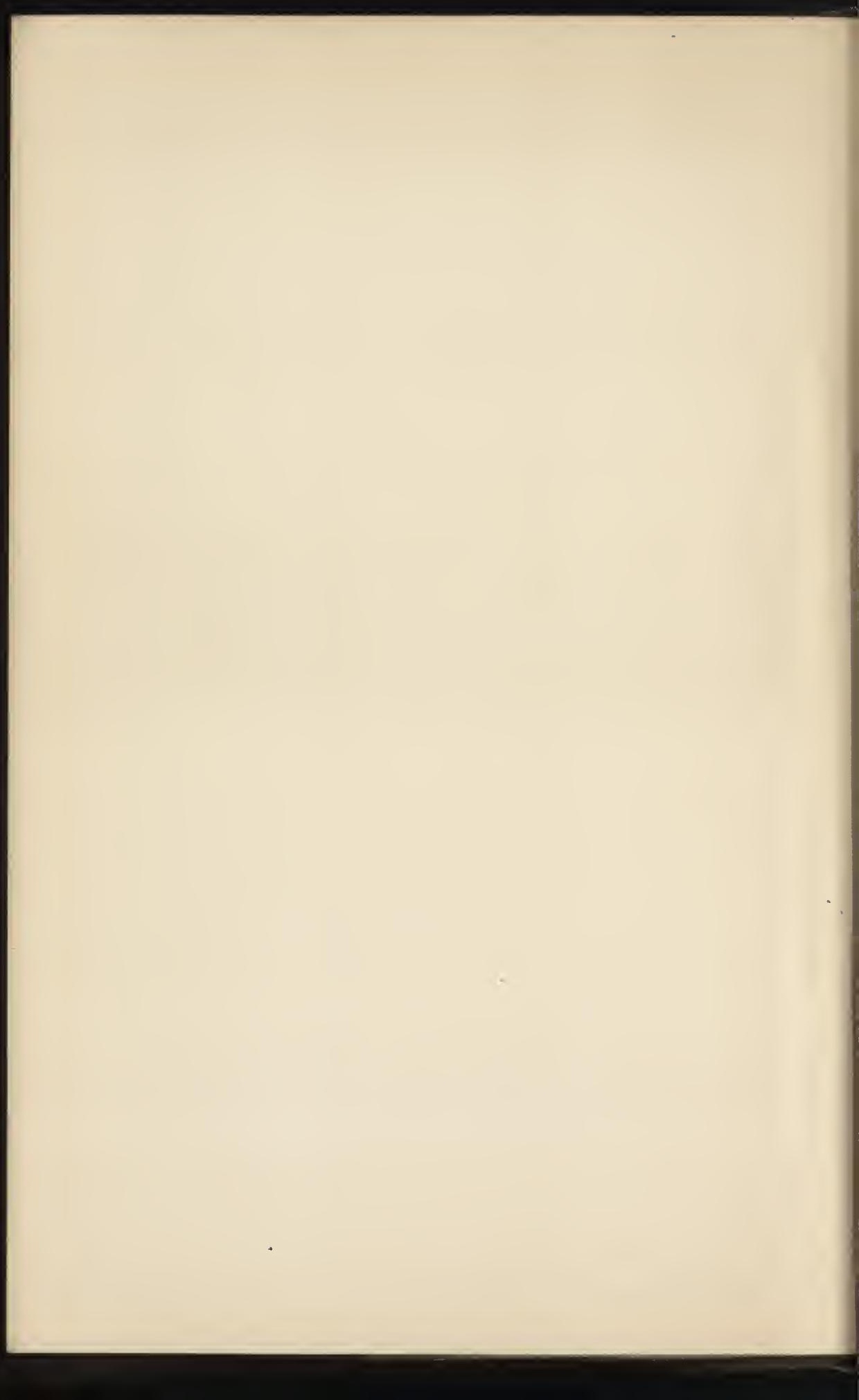




\section{THE TANNINS.}

\section{SECTION I.}

THE DISCOVERY OF THE TANNINS.

THE history of tannin as a proximate principle takes its beginning in France during the period between 1790 and 1800. Previous to that time the histories of leather, galls, and oak-bark are our only sources of information regarding the development which led to the discovery of tannin.

Grcat discoveries are rarely made without some warning; in reviewing their origin we see that they have had a gradual birth, and the exact date which indicates the beginning of their existence cannot be determined. In these evolutions of a discovery there are sometimes periods of comparative inactivity, succeeded by sudden and great advances. The history of tannin has not been an exception to the rule of gradual discovery, for we find among the earlier writers on the subject a disposition to attribute the astringency of galls and oak-bark to some peculiar principle, which, however, they did not separate or name.

Dr. William Lewis, in his "Philosophical Commerce of the Arts, "London, 1763," calls attention to 
the presence of a substance in certain vegetable infusions, which, when mixed with "green vitriol," produces "a deep black liquor, of most extensive use for dyeing and staining black. The power by which they produce this blackness and their astringency, or that by which they contract an animal fibre, seem to depend upon one and the same principle, and to be proportional to one another." "Of the propcrties of this colouring and astringent matter, little more is known than that it is dissolved and cxtracted from the subject both by water and spirit of wine, and that it does not exhale in the evaporation of the liquors by heat."

English writers on tannin usually ascribe to Dr. Lewis the honor of having a part in its discovery, but further than for writing the above quotation of facts, which werc well known before his time, it is unreasonable to give him credit.

$\mathrm{He}$ was followed by other investigators, chiefly on galls and oak-bark, especially in the relation of the latter to tanning, which gradually led to the discovery of gallic acid by Scheele in 1786 .

Dizé in 1791 repeated Scheele's experiments on galls, obtaining similar results; but he went further, and separated what he called a resinous substance by means of ether. It was unchanged on exposure to air, possessed an herbaceous taste, dissolved readily in water, and this solution formed a white precipitate with sulphuric acid.

Two years later, in 1793, Deyeux, a French chemist and apothecary, published a memoir giving the results of an elaborate series of cxperiments, preceded by a description of the Aleppo and some other varietics of 
galls. It is then stated that, "in the number of properties which appertain to nutgalls, there is one, very remarkable, which has always fixed the attention of chemists,-namely, the preeipitate of the solution with the solution of iron salts. This has been attributed to an astringent body,- ' principe astringent.'

"Among those who have occupied themselves" with this subject may be mentioned Cartheuser, Ronelle, Maequer, Monnet, and Giannoti; but it is principally the academicians of Dijon, likewise Scheele, Berthellot, Fourcroy, and others, to whon we are indebted for the positive knowledge of this singular substance. They have demonstrated the existence of a peeuliar acid which they have named gallie acid. This has made desirable a knowledge of the other constituents, and it is this whieh is made the subject of the following memoir."

The record of the experiments was made under eight seetions, as follows :

1. "The action of water on nutgalls.

2. "The action of alkalies on the infusion and decoction of nutgalls.

3. "The action of aleohol and ether on nutgalls.

4. "Distillation of nutgalls with water.

5. "Dry distillation of nutgalls.

6. "Examination of the gallic acid which sublimes during the distillation of nutgalls.

7. "Examination of the precipitatc which forms when nutgalls, their solution, and gallic acid are added to ferrous sulphate.

8. "Recapitulation."

This last section may be briefly stated as follows :

Nutgalls are composed of (1) a true extractive mat- 
ter, (2) a peculiar resin, (3) a green eoloring-matter, (4) gallic acid, (5) ligneous tissue. "All of these bodies except the ligneous tissue are in strong combination, resulting in a body soluble in alcohol, ether, and water. It is to this body entire and not to any principle in particular that the astringency belongs, sinee none of these eompounds alone possess it."

In terminating this memoir the author expressed the hope that others would repeat his experiments and rectify his crrors.

It has bcen quoted at some length because it is a record of experiments that for ingenuity and accurate reasoning would do credit to any investigator at the present time. The author was wrong in some of his deductions, but, when we consider that then all was darkness where now we have some light, it may not be far wrong to say that he eame much nearer the truth than does many a one in our day when examining a new substance.

It is due Deyeux to say that he diseovered tannin when he exhausted nutgalls with ether and described the product as a "refincd dry and friable extraet." On account of the gallic acid, he overlooked the possibility of there being a still more important substance present. All previous investigators had pointed so strongly to gallic acid as the principal constituent that, notwithstanding he found what he named a peculiar resin to be present in great abundanee, he was unable. or unwilling to realize it. Finally, he failed to distinguish between gallic and pyrogallic acids, but others also had failed to detect that difference.

We find at this time that the desire to improve the 
process of tanning was the great ineentive which led to a more exaet knowledge of tannin. One of the ehief objects in view was to shorten the proeess, and the idea of extraeting the oak-bark or tan with water is usually attributed to Seguin, but previous to his patent was the suggestion of Macbride in 1795 to extraet the bark with lime-water, and that of Anthony Fay to make an extract by boiling the tan with water in the proportion of one pound of the former to three gallons of the latter. This extraet, or ooze, as he termed it, was to be weakened with water and used for tanning, whieh it aceomplished in one-half the time oeeupied by the methods then in use. Fay's patent was dated January 17, 1790, although not published until 1796. Seguin's patent appears to have been dated in Franee in 1795 and in England in 1796, in the latter ease under the name of William Desnıond.

To afford an understanding of what bearing these patents, especially Seguin's, had on the discovery of tannin, it will be neeessary to state that previous to his investigations the process of tanning was not supposed to be one of a eombination of tanuin with animal membrane, but simply a physieal proeess in which the astringent property of the bark eaused the hide to shrivel, harden, and beeome non-putreseible; therefore, when Seguin reasoned from his experiments, whieh were ehiefly eondueted on quite a large scale in the tanyard, that there was a prineiple present in oak-bark which eombined with liide to form leather, lie was given the eredit of diseovering tannin, although it had previously been separated and reeognized as a distinct substanee by both Dizé and Deyeux. 
Seguin's conclusions werc strengthened by the fact that, when he boiled hide with watcr and added to the clear cold liquid an infusion of oak-bark, he obtained a light-colored precipitate, which was insoluble in hot or cold water and became dark on exposure to light.

We derive our knowledge of Scguin's experiments from the report of a committee appointed to cxaminc his process; after some months' investigation, during which time a hundred or more hides were tanned and the committee wore shoes made of the leather, a satisfactory report was made and published. The committee consisted of the citizcns Lelievre and Pclletier.

Seguin's method of preparing the liquor was somewhat different from that of Fay. The latter, it will be remembered, boiled together the bark and water, whilc the former poured the liquor from onc lot of ground bark to another until it reached a strength of from $10^{\circ}$ to $12^{\circ}$. The advantage claimed for this form of thc tanning matcrial was that it could be transported, and, as the committee feared the early extinction of forests in France, they suggested that such an extract could be made in America.

The first separation of tannin in a purc condition was accomplished by Proust in 1798. Hc added a solution of stannons chloride to a decoction of galls, and produced an abundant yellow precipitate, which he stated to be a combination of the tanning principle with tin and free from gallic acid. The precipitate mixed with water and treated with hydrogen sulphide was decomposed, forming a sulphide of the metal, which precipitated, while the astringent principle remained in solution. After removing the sulphide by 
filtration, the solution was evaporated in a silver basin, yielding a deep-brown, friable residue, which possessed the characteristic odor of the astringent principle. It had a vitreous fracture and did not attract moisture from the air. The tastc was strongly astringent, and it completely dissolved in water and alcohol. The solution of this extract added to a solution of glue formed a magma which possessed the elastic properties of the gluten of flour, was perfectly insoluble in hot water, and was not susceptible of putrefaction. This the author believed to be the secret of Seguin's preservation of leather. The remainder of his interesting memoir was devoted to the effects of tannin and gallic acid on ferrous and ferric salts. He also pointed out the fact that the juice of sumac gave the same reaction as this compound from galls.

By these four investigators the existence of tannin was completely establishcd, and gallic acid became of secondary importance as a constituent of galls and in tanning. It may be briefly stated that Dizé first indicated the existence of tannin and prepared it in an impurc state, Deyeux prepared it in considerable quantity and recognized it as one of the important constituents of galls, Seguin considered it the tanning principle and put the knowledge of its cxistence to practical application, and Pronst first prepared it in an almost pure state.

In 1801, Karsten reviewed the history of tannin, and attributed the discovery wholly to Seguin, although he spoke highly of Proust's work. It is very probable that his credit to Seguin was on account of the great practical importance of the latter's invention, which 
gave it extcnsive publicity, while the more scientific works of Dizé and Deyeux were overlooked.

In 1802, Proust wrote another memoir on tannin, in which he concluded that there were many different kinds of tannin in different plants. This appears to be the first statement of what has since proved to be a most important principle in the study of the tannins, and with this work of Proust the history of the discovery of tannin may well be closed, and further historical considerations taken up under the individual members of the class. 


\section{SECTION II.}

\section{GENERAT, CHARACTERS.}

The terms "tannin" and "tannic acid" arc used indiscriminately by many writers, while others employ the term "tannic acid" to indicate the whole series and "tannin" to denote the product from oak-galls. It, however, appears more rational to apply the term "tannic acid" to the produet from galls, since it is an aeid when pure, and to use the term "tannin" to designate the whole class of astringent substanees, many of which are glueosides, and many more hold an unknown position among the chemical eompounds. Thus "tannic acid" will agree with the German gerbsëure and the French acide tannique, and "tannin" with the German gerbstoff and the French tannin, although many writers in those languages have also confused the respective terms. There is no objection to the use of a more cxact designation by prefixing the souree of the compound, as gallotannic acid to the produet from galls, "sumactannic acid to that from sumac, catechutannin to that from catechu, etc. In the following pages, therefore, the term "tannin" will be applicd to the whole class of astringents, while the compound from galls, as well as those from other sourees where they have been shown to be chemically and physically identical with it, will be designated by "tannic acid." In both cases a prefix indicating the source will bc applied when necessary. 
The tamnins may be defined as a class of amorphous, astringent, vegetable substanees, the nembers of which prodnce a blue or green color and precipitate with salts of iron, and with animal membrane form an insoluble and imputrescible compound called leather.

The tannins are widely distributed throughout the vegetable kingdom. The richest deposit appears to be in galls, of whieh they comprise from twenty-five to seventy-five per eent., according to the variety. The next most abundant source is the inner bark of certain trees, notably of the oak species; they are also found in leaves, umripe fruits, woods, and some buds and flowers, but rarely and in small quantity in secds.

Many theories have been advanced by different investigators to explain the uses and method of formation of the tannins in plants. It has been observed that starch is always present with tamnin in barks; that in many respects the tannins resemble the resins: the members of both classes, when heated with potassium hydrate, yield the same or similar products of deeomposition, and, further, when seeds which arc free from tannin germinate, it may then be detected. It has been found that the amount of tannin in a plant varies greatly with the time of year, and in some cases ehanges with the variation in the amount of starch present, as shown by Peacock in Heuchera Americana. He determined the amount of tannin to be greatest in October and least in May, while the starch was greatest in March. In Geranium maculatum it has bcen found by the author that the tannin is present in largest amount in April, just before the plant blooms, and rapidly deereases until it reaches a minimum in 
Oetober, thus pointing to the possibility of its being a storage material to assist the plant in blooming and perfeeting its seed.

The questions which naturally arise from a eonsideration of the various faets are, Do the tannins result from the deeomposition of starch? Are they closely related to the resins? Are they a reserve material, or simply a useless by-product? These problems remain to be worked ont, and the answers may be found to vary with the kind of tannin. For instance, gallotannic acid is simply a morbid deposition of the compound resulting from the sting of an insect, while the other tannins vary according to the eircumstances under which they have been formed.

Probably the most reeent contribution to this subject, and one established on many experiments, is the monograph of Krans, who has established some facts concerning the formation of tannin, but has not offered a solution of the various problems. He considered the tannins of different origin to be physiologieally alike. This was stated soon after by Reinitzer to be incorrect. Kraus further found that light and earbon dioxide are essential agents of the formation of tannin in leaves. Leaves whieh are not green are not eapable of prodncing tannin. The onter leaves of a plant, exposed to direct sunlight, contain more tannin than the inner leaves. It is not a product of the assimilation of chlorophyll grains ; the oak, willow, and alder assimilate in dull weather without inereasing in tannin. The tannin produced in the leaves passes into the branches and roots, and there is no cxperimental evidence that the tannin which has once passed into the rhizome undergoes further 
ehange; there is rather an inerease in the amount of tamnin in the rhizome through a produetion in the dark. Kraus inclined to the belief that the nse of tannin in leaves is cither to protect them from being eaten or to prevent rotting, ete. Fallen leaves eontain as much tannin as they did during their best time of growth, indieating that the leaf tannin is of no value to the plant. During the germination in the dark of seeds containing tannin, as oak and horse-chestnut, there is no diminution, but an inerease, in the amount of tannin. There is not yet suffieient evidenee to show whether tannin is produeed from non-nitrogenous substanees, or whether it is formed in the eonversion of nitrogenous compounds into albuminoids. Finally, Kraus eonsidered it probable that aromatic compounds may be formed in the produetion of albumen, some of which are used in the building up of albumen while others yield tannin. His investigations and conelusions rested on slight differenees in the estimation of tannin, and Reinitzer claimed that the methods employed for the estimation of tannin are not suffieiently exact for physiologieal investigation. This is no doubt true of estimations made by different chemists, but one person should be able with the present methods to get results which are relatively aceurate.

It was early suggested to divide the tannins into two elasses, - the iron-bluing tannins, or those which give blue precipitates, and the iron-greening tannins, or those which give green precipitates with salts of iron. It las been found, however, that the same tannin may produce both blue and green precipitates with iron salts. Free aeid, especially tartarie, eauses the green eolor, 
and, on the other hand, an iron-greening tannin may be changed to an iron-bluing one by the cautious addition of alkali.

A more recent and much more exact classification is that of Wagner into pathological tannins, those formed on vegetable tissue by the sting of an insect, and physiological tannins, those occurring in vegetable tissue. To the former class belongs gallotannic acid, and to the latter the great number of tannins found throughout the vegetable kingdom. The former give blue and the latter give both blue and green precipitates with salts of iron. It has been found that some of the latter class are identical with gallotannic acid ; this was first pointed out to be true of sumactannic acid by Stenhouse, and was later confirmed by Löwe.

The method of preparing a tannin depends very much on the character of the material in which it occurs. Most of the published processes are based on the use of galls as the source, and a process available for exhausting them is not adapted to extracting a hard woody substance containing only five or ten per cent. of tannin. A process will, thereforc, be given for each tannin, unless it can be referred to the following general method, which will be found available in many cases.

The finely-powdered material is packed in a percolator and extracted with commercial ether. The official ether of the United States Pharmacopœia, containing seventy-four parts ether, twenty-six parts alcohol, and a small quantity of water, gives satisfactory results; its specific gravity is very close to 0.750 . The ether is recovered by distillation, the last portions being removed

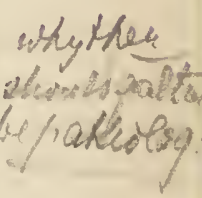


under reduced pressure, and the residue is dissolved in such a quantity of water as will allow the solution to filter readily. This aqueous solution is distilled to dryness under rednced pressure, and the residue dissolved in a small quantity of water and rapidly distilled to dryness in as ncar a vacuum as possible, using in this, as in the preceding cases, a water-bath as the source of heat, when the tannin will "puff up" and remain as a lightor dark-brown residue, according to the character of the original material. It may then be purified according to the method given later for the purification of gallotannic acid. This process may be used for most substances which contain five per cent. of tannin or over ; but it is well to bear in mind that there is no separation of the percolate into layers, as in the case of that from galls.

If lcss than five per cent. of tannin be present, it is more economical to extract with water and precipitate the tannin with lead acetate. The resulting lead tannate is then suspended in water, decomposed by hydrogen sulphide, and the filtrate from lead sulphide distilled to dryness nuder reduced pressure. Alcohol is sometimes used, butwhere the solvent can be recovered it has few if any advantages over ether. When ceonomy is the first consideration hot water is used, and this will later claim especial attention under tannin extracts. In a few eases cold instead of hot water must be used or the impurities will predominate, as in the case of eanaigre, which contains a large quantity of starch that is dissolved with the tannin by hot water and interferes with the use of the extract for many purposes.

Always when a pure tannin is desired heat and exposure to air must be avoided. Many plants appear 
to contain two tannins; when such is the case it will sometimes be found that ether extracts one, and the other may then be removed by water, or oceasionally cold water will extract but one and the other may then be removed by the use of hot water.

The tamnins as a class arc amorphous, odorless, slightly acid, and strongly astringent compounds, of a color varying from dark brown to pure white. They are, with few exceptions, soluble in water, alcohol, ether, and glycerin, and insoluble in ehloroform, benzol, petroleum ether, earbon disulplide, fixed and volatile oils.

In addition to the above reactions given with iron salts, most if not all the tannins give brown precipitates with potassium bichromate. Lime-water gives precipitates, which, however, vary in eolor ; at first they are white, but become rapidly darker, some red and others blue. Strong solutions of the alkaline carbonates also precipitate them. All the tamnins are precipitated by gelatin or albumen; solutions of alum and ammonium cliloride render the precipitation more complete. Satnrated solutions of sodium chloride, calcium ehloride, potassium acetate, and a number of other salts precipitate the tamnins from solution; the same is true of moderately concentrated sulphuric and hydrochloric acids. Concentrated snlphuric acid dissolves the dry tannins with a ycllow color, which on heating become dark-red rufigallic acid and then black metagallic acid. Nitric acid does not precipitate the tannins from solution, but it dissolves the dry eompounds with a yellow color, and decomposes them with the formation of oxalie acid. Otlier oxidizing reagents, as potassium 
bichromate and permanganate, decompose them very easily into carbon dioxide and some other unknown compound. When heated dry with arsenic acid, some of them arc converted into ellagic acid. Most tannins are precipitated by alkaloids, notwithstanding the fact that both frequently exist in the same plant without forming an insoluble compound. The action of dilute acids and alkalies is one of considerable importance in determining their character; some, for instance, when heated to $100^{\circ}$ with a one or two per cent. hydrochloric acid solution, yield crystalline compounds as gallic and ellagic acid, while others yicld dark-colored amorphous compounds allicd to the phlobaphenes; glucose is formed at the same time in nearly all the decompositions, thus showing their glucosidal nature.

Another method of determining the character of tannins is by the application of hcat. When a tannin is heatcd to $120^{\circ}$ no decided change takes place except a slight darkening in color; on continning the heat the color gradually becomes darker, until at $160^{\circ}$ decomposition takes place. With some tannins the products are metagallic acid and pyrogallol, and with others metagallic acid and catechol. It has been suggested to divide the tannins into two classes according as they yield, when heated, pyrogallol or catechol. 'Those which produce a brownish-colored deposit on leather, called "bloom," and form blue componnds with ferric salts yield, when heated, a sublimate of pyrogallol, while those which do not form a "bloom" on leather and give green compounds with ferric salts yield, when heated, a sublimate of catechol. To the former class belong the tannins from galls, sumac, 
chestunt, and oak, and to the latter those from hemlock, catechu, rhatany, and mangrove. It is known not only that the tannins in the two classes have a different composition, but that most of those in the same class differ from one another in many partienlars. In order to assist one in determining the eharacter of a tannin it is necessary to study its deeompositions by heat alone, by acids, and by alkalies.

Procter, in his "Text-Book of Tanning," and Allen, in his "Commercial Organic Analysis," have given similar schemes for earrying out these three processes.

The decomposition by heat may be effected by heating the sample in a small glass retort, but this is attended with considerable loss from a portion becoming overheated. The deeomposition should take place by slowly raising the temperature from $160^{\circ}$ to $215^{\circ}$, keeping it between $200^{\circ}$ and $210^{\circ}$ for twenty minutes. It has been suggested to assist the sublimation of the volatile products by leading a streanı of carbon dioxide into the retort to carry them off as rapidly as formed.

Thorpe suggested a method of preparing pyrogallol for photographic purposes by heating gallic acid in glyeerin as above directed, and this has since been applied to deeomposing the tamnins.

The details of the method are to heat one gramme of the tannin in 5 ce. of glycerin, slowly raising the temperature from $160^{\circ}$, and keeping it for from twenty to thirty minutes between $200^{\circ}$ and $210^{\circ}$. It is then allowed to cool, 20 ee. of water are added, and the liquid is shaken with an equal volume of ether without previous filtration. The separated ethereal layer is evaporated to dryness and dissolved in 50 ce. of 
water and tested for pyrogallol and catechol, according to the following:

\begin{tabular}{|c|c|c|}
\hline & \multicolumn{2}{|c|}{ ONE PER CENT. SOLUTIONS OF } \\
\hline & Pyrogallol. & Calechol. \\
\hline Ferric chloride . . & $\begin{array}{l}\text { Red color, turning } \\
\text { brown. }\end{array}$ & Green color. \\
\hline Ferric acetate ... & Dark-purple color. & Green color. \\
\hline Lime-water . . . & $\begin{array}{l}\text { Purple color, turn- } \\
\text { ing brown. }\end{array}$ & Clear red color. \\
\hline Melting-point . - & $131^{\circ}$ & $111^{\circ}$ \\
\hline $\begin{array}{l}\text { Pine wood moistened } \\
\text { with } \mathrm{HCl} . .\end{array}$ & No change. & Violet color. \\
\hline
\end{tabular}

The above tests will readily distinguish betwecn pyrogallol and eatechol when either occurs singly or mixed with only a small proportion of the other, but when they occur in a solution in nearly equal proportions it becomes a matter of much more difficulty. The tannin should be free from gallic acid and catechin before submitting it to the above operation, or clse pyrogallol will be obtained from the former and catechol from the latter; this may be ảccomplished by thorough agitation of an aqueous solution of the tamnin with ether and separation of the latter, the water is then rapidly distilled from the tannin under reduced pressure.

It has becn found by the author, in carrying out the application of heat to tannins, that there is a practical difficulty in scparating the ethereal layer containing pyrogallol and catechol when the 5 cc. of glyccrin, after the application of heat, are dissolved in 20 cc. of water and agitated with ether. The emulsion formed 
is difficult to get rid of. This may be overcome by agitating the $5 \mathrm{cc}$. of glyccrin directly with $20 \mathrm{cc}$. of ether without first dissolving in water, or the sample of tannin may be heated with 5 grammes of paraffin, instead of 5 cc. of glycerin, and the paraffin dissolved in petroleum cther ; the residue is then treated with water and agitated with ether, the ethereal solution separated as before, cvaporated, and the residue dissolved in 50 cc. of water, when it is ready for testing.

In order to determine the effect of dilute acids on a sample, a convenient quantity of the latter is heated for an hour or more to $100^{\circ}$ with a two-per-cent. solution of absolute hydrochloric acid. This may be accomplished by heating in a sealed tube or strong flask tightly stopped, or by attaching the open flask to an upright condenser and heating with a vigorously boiling water-bath. The solution, after sufficicnt heating, is allowed to cool, when a separation of insoluble matter indicates ellagic acid, anhydrides, or phlobaphenes. The mixture is filtered, if a separation has taken place, and the precipitate tested for ellagic acid by nitric acid, with which it forms an intense crimson color. The filtrate containing hydrochloric acid, undecomposed tannin, gallic acid, and glucose is agitated with ether to remove gallic acid, neutralized with sodium hydrate, and precipitated with basic lead acetate to remove coloring-matter and tamnin. The excess of lead is removed with sulphuric acid, again neutralized with sodium hydrate, and the clcar filtrate heated with an excess of Fehling's solution. The formation of a red precipitate of cuprous oxide indicates the presence of ghucose. 
The ethereal solution which removed gallie acid is evaporated, the residue, dissolved in warm water, allowed to eool, and filtered, when gallic aeid, if present in the filtrate, may be deteeted by the red eoloration produced by the addition of a few drops of potassium cyanide solution.

Since glueose oecurs as a mixture in most tannins, it is neeessary first to get rid of it before applying the above process. This may be aecomplished by repeated purifieation of the tannin by preeipitation with lead acetate; but such a proeess is very slow and tedious: so it has been suggested to use the lead salt for heating with the aeid, in whieh case the sediment whieh separates when the liquid cools will consist in part or all of lead ehloride, whieh may be colleeted on a filter with the ellagie aeid and treated with boiling water, in which the lead ehloride will dissolve.

It lias been found by the author that the shortest method is to determine the amount of glueose in a tanuin by removing the latter with lead acetate, and the exeess of lead with hydrogen sulphide. The filtrate is then heated on a water-bath until every traee of hydrogen sulphide is driven off, neutralized with sodium hydrate, filtered, and the glueose estimated in the filtrate gravimetrieally with Fehling's solution. Another portion of the sample is then heated with lyydroehlorie acid, and, after earrying out the proeess of hydrolysis, the glueose is estimated. Any exeess of glueose in the seeond estimation over that in the first indicates that much glueose existed in the tannin as glueoside.

The aetion of alkalies is determined either on a sample 
of the tannin or on the anhydrides and phlobaphenes resulting from the action of hydrochloric acid. This process of lieating the tannins with alkali converts some of them into protocatechuic acid and cither phloroglucol or acetic acid,--to this class belong the catechol tannins. Another class are converted into gallic and ellagic acids by the alkali, and they are found to be the pyrogallol tannins. The opcration is carried out by taking 20 grammes of the sample and boiling for three hours with $150 \mathrm{cc}$. of potassium hydrate solution, specific gravity 1.20 ; the liquid is then concentrated with constant stirring until it becomes pasty. It is then cooled and neutralized with dilute sulphuric acid, filtered from the potassium sulphate, and the filtrate treated with sodium bicarbonate until the acid is neutralized. The liquid is agitated successively with several portions of ether ; the latter, after separation, is recovered by distillation, and its residue dissolved in water; from this solution protocatechuic acid is removed by lead acetate, filtered, and the phloroglucol, when present, removed from the filtrate by ether; the latter is evaporated, and the phloroglucol is recognized by its sweet taste, by ferric chloride, which imparts to its aqueous solution a deep violet-red color, and by bromine-water, whicl causes a scparation of crystalline needles, with cvolution of heat and a very irritating odor.

With these various charactcrs of the tannins our knowledge of them almost ceases. Except gallotannic and quercitanic acids the individuals lave not been much studied, and the latter are only now in course of investigation by Böttinger. As recently as 1881, Darton, who has had considerable expericnce in the assay of 
various tannin materials, ventured to repeat the conclusion of the older chemists that we have but one tannin, and that the differences are due to the other materials with which they are assoeiated in the plant. It is true that one is often led, during the praetical study of the subject, to ask whether wc have more than one tannin or not, but this question is being answered as the study into the constitution of the various members is prosecuted. No doubt some relationship governing them cxists, just as there is among the sugars, but as yet it has not been made out, and the study will necessarily be a long one, sinee there are so many individual taunins to be investigated. The problem will undoubtedly be worked out by a study of the derivatives, and this by means of bromine and acetyl has been wcll commenced on the gallotannic and quercitannie acids. We must kcep in mind that a number of the individual tannins will be proved to be identieal, as has been shown to be the casc with sumae and a few others in regard to gallotanuic acid, but with the grcat majority our present knowledge leads to the belief that a relationship only is to be worked out.

In general it may be said that the tannins are used in medicine, in the manufacture of leather and ink, and as a mordant in dyeing, but the special properties of the different members adapt them to a great number of minor uses. By far the largest amount of tannin is used in an impure state, - that is, in the form of an infusion or decoction, or as an cxtract, made by concentrating these solutions. 


\section{SECTION III.}

THE DETECTION AND ESTIMATION OF THE TANNINS.

THE simple detection of the tannins is comparatively easy. A few tests applied to an infusion of the plant or substanee serve to deeide their presence or absence.

Ferric acetate or chloride is usually first employed, when a green or blue color and preeipitate indieate tannin. Ferrous salts, when free from ferric, cause no change with tannin solutions unless the latter be concentrated, when a white gelatinous precipitate is formed, rapidly becoming dark on exposure to air. Potassium dichromatc forms brown precipitates with nearly all tannins. Ammoniacal copper sulphate forms preeipitates of different shades of color ; but, aceording to Procter, the tannin of Hungarian larch is not precipitated by this reagent, and it does form insoluble compounds with some substances other than the tannins. Allen recommends an ammoniacal solution of potassinm ferricyanide, which produces with the tannins a deep-red color changing to brown, even in very dilute solutions. Most of the alkaloids, when not in too dilute solution, produce whitish precipitates with the tannins. Calcium hydrate produees a whitish preeipitate rapidly turning blue with gallotannie, but red with some other varieties, notably that from mangrove. An aqueous solution of iodine in potassium iodide, mixed with a small quantity of ammonia previously 
diluted with ten times its volume of water, will produce a brilliant red color with solutions of the tannins, even when highly diluted.

Other characteristie tests for the tannins will be found under the chemical propertics of the different varieties.

The methods for the quantitative determination of the tannins may conveniently be eonsidered in four groups :

1. Miseellaneous methods, not belonging to any of the following.

2. Precipitation by metallic salts.

3. The gelatin or hide methods.

4. The permanganate methods.

1. Under the first class is the process of Commaile, which was based on the reduction of iodic aeid by tamin in the presence of hydroeyanic acid. The iodic acid not consumed was estimated by reduction with sulphurous aeid and preeipitation by silver nitrate. This method has been unfavorably eriticised by Cech and by Watts.

F. Becker suggestod the use of methyl violet, 0.250 gramne in one litre. This was standardized by a oneper-cent. tannin solution, and it could then be used on tamnin solutions of unknown strength.

Mittenzwey recommended a process in which the volume of oxygen absorbed by an alkaline solution of tannin was measured. Cech found this to give unsatisfactory results, but Watts, after improving some details in the apparatus, eonsidered it a fairly aecurate method.

Wagner proposed titrating the tamnin solution with cinchonine sulphate, using rosaniline acetate as an indi- 
cator. This method failed to give satisfaction, on account of the difficulty in determining the end of the reaction. Clark used a modifieation of this for the estimation of tannin in tea. His improvement consisted in adding an excess of the cinchonine sulphate, filtering, and estimating the excess of the alkaloid by titrating with potassio-mercuric iodide. A series of trials, by the author of this volume, in which the method was tried on gallotannic aeid, failed to give concordant results.

F. Musset suggested using an excess of standard solution of iodine, and, after twelve hours' standing, titrating the free iodine with standard sodium thiosulphate, which was added in excess and titrated with decinormal iodine solution and stareh.

2. The methods of preeipitation with metallic salts are very numerous and comprise many modifieations. It is desirable sometimes to obtain the value of a tannin by this means, therefore the following more important processes will be given.

Pribram in 1866 detailed a method involving precipitation by lead acetate, washing, drying, and weighing the precipitate; but, as there are at least three salts of lead tannate, according as the lead acetate or tannin is in excess, and these salts are readily decomposed by washing, it is evident that such a method can only give approximations.

Allen originated a modifieation of this for assaying the tannin in tea, in which the latter in hot coneentrated solution was titrated by a volumetrie solution of the lead acetate; the end of the reaetion was ascertained by filtering a small portion of the liquid and testing with 
ammoniaeal potassium ferricyanide, which gave a red color turning brown as long as any uncombined tannin was present. As stated by its author this estimation included gallic acid, so would not be available for all cases.

Dragendorff $^{1}$ recommended that precipitations with lead acetate should be earried out in moderately concentrated solutions, avoiding an exeess of the lead salt and not continuing the washing too long.

R. Jackson suggested the use of lead carbonate with which to agitate the tannin solution. The speeific gravity before and aftcr the treatment giving the loss of tannin, a difference of .0038 indicated one per cent. of tannin.

For the estimation of tannin in plant analysis Dragendorff recommended estimating the tannin soluble in absolute aleohol, after replaeing the solvent by water, by precipitating with lead acetate, rapidly washing, drying, and wcighing the precipitate, which was then burned and the residue of lcad oxide subtracted from the original weight. This opcration was then rcpeated with copper acetatc. When the amount of organic matter precipitated by each was equal, the substance was assumed to be tannin; but, in case the lead salt preeipitated more than the copper salt, the organic matter obtaincd by the latter was taken as representing the amount of tannin, while the excess obtained by lcad aeetate over that by copper acetate was rcckoned as. other organie acids and coloring-matter.

Copper acetate appears to have been first suggested for the quantitative determination of tannin by Sakur.

1 Plant Analysis, English edition, p. 41. 
The preeipitate with it, like that of the eorresponding lead salt, is not of eonstant eomposition; therefore the preeipitation must be made with moderately eoncentrated solutions, and the resulting preeipitate rapidly washed, dried, and weighed. Fleek preeipitated the tannin by eopper aectate, and washed the precipitate with ammonium carbonate to remove gallie aeid. The preeipitate was then washed, dried at $100^{\circ}$, weighed, and ignited. Wolff found 100 parts of eupric oxide represented 130.4 parts of tannin.

Pavesi and Rotondi found 100 parts represented 145 parts tannin. This differenee among different investigators Sehiff explained by supposing they used tannins of variable degrees of purity, and he found 136 parts of pure digallie aeid to be represented by 100 parts of cupric oxide.

J. Persoz reeommended dissolving eight grammes of ammonium chloride in one litre of water, and in this dissolving some stannous chloride. Ten grammes of pure dry tannin were then dissolved in one litre of water, and 100 ee. of this solution preeipitated with $100 \mathrm{ce}$. of this stannous ehloride solution, the mixture allowed to stand ten or twelve hours in a graduated cylinder, and the volume of the precipitate read. Then ten grammes of the tannin material were boiled for one-half hour with a half-litre of water, filtered, and the residue washed with suffieient water to make one litre; 100 ee. of this solution in a similarly graduated cylinder were then preeipitated with $100 \mathrm{ec}$. of the stannous ehloride solution, and after standing ten or twelve lours the volume of the precipitate was eompared with that from the pure tannin. 
Risler-Beunat proposed to modify the method by eollecting the precipitate of tin tannate, washing, drying, and igniting, with the addition of a little ammonium nitrate in order to eompletely convert the residue into stannic oxide. The weight of this residue was converted into tannin by a calculation based on the amount of residue obtained from a pure dry tannin. Dragendorff found that the precipitation was incomplete, that it took plaee slowly, and that the preeipitate was partly decomposed by washing.

Gerland suggested the use of tartar cmetic in the presence of ammonium chloride for the volumetric estimation of tannin; the method, however, met with little favor until improved by Richards and Palmer, who used ammonium acetate instead of the chloride, both of which prevent the preeipitation of gallic aeid and assist the precipitation of the tannin. The tartar emetic was dried at $100^{\circ}$, and then used in the proportion of 6.730 grammes in one litre; in such a solution 1 ce. corresponded to 0.010 gramme of digallie acid. The ammonium acetate was made by saturating glacial acetic acid with strong solution of ammonia, and $1 \mathrm{cc}$. of this solution added to every 25 cc. of the tannin solution, which latter should contain from 0.1 to 0.3 gramme of tannin in every $100 \mathrm{ce}$. Three or four tests should be made in as many beakers plaeed side by side, and the end of the reaction determined by placing a drop of the clear supernatant liquid on a white porcelain surface, adding a drop of sodium thiosulphate, and warming; a red color of antimony sulphide will form when the least exeess of the reagent has been added.

Ammoniacal rine aeetate was recommended by 
Terreil in 1874, by Carpenè in 1876, and by Barbieri in 1877: While the details of the different authors varied somewhat, the following covers most of the methods. The reagent was added to a boiling solution of the tannin, and the mixture concentrated to one-half, when it was cooled and filtered. The precipitate was dissolved in dilute sulphuric acid, and the tannin estimated by titration with potassium permanganate. This process was especially recommended for determining the tannin in wine, but Dragendorff found it of little value.

Handtke used ferric acetate in the presence of sodium acetate, and found it available for the estimation of the tannins of oak-bark, valonia, dividivi, sumac, and catechu, when the concentration was such that the precipitate yielded 45.8 per cent. of ferric oxide by ignition; but with a number of tannins it did not yield satisfactory results, and the process is apparently not used.

3. Methods of estimating tannins by means of gelatin, isinglass, and hide or hide powder have been suggested in great number, with as many or more modifications by others until the list is a formidable onc. Apparently the first paper on the quantitative determination of tannin was by George Biggin in 1799, who collected, washed, dried, and weighed the precipitate produced by gclatin on tannin. He did not attempt to arrive at the exact amount of tannin present, as he made no estimation of the value of the precipitate in tannin. It could, therefore, be used only to compare one material with another, and was available only to the tanner who wished to compare the value of a new substance with that of a well-known onc he was using.

Davy in 1803 extracted six parts of bark with 
water and preeipitated it with one part of isinglass, washed, dried, weighed the preeipitate, and ealeulated 40 per eent. of it as tannin.

Müller suggested the addition of alum to the isinglass or gelatin solution, and a solution of three grammes gelatin and one gramme alum in one litre of water is largely used at the present time in two modifieations, -one to eolleet, wash, dry, weigh the preeipitate, and reekon 54 per eent. of it as tannin ; the other to use the solution, volumetrieally and determine the end of the reaction by filtering off a small portion of the solution and testing until no further preeipitate is eaused by the reagent. The solution of gelatin and alum must first be standardized by a solution of pure tammin. Notwithstanding the objeetion to this method, and the fact that we have many others for whieh greater aeeuraey is elaimed, it eontinues to be used, and, no doubt, in eareful and experieneed hands will yield uniform results.

The following details of this proeess have been employed by the author for several years with considerable sueeess. The results have in most eases agreed elosely with those obtained by the permanganate method. The solution is made of 2.5 grammes gelatin and 10 grammes alum in one litre. This solution, as well as that of the tamnin, is warmed to $70^{\circ}$. The reagent is then dropped in with eonstant stirring until the precipitate eoagulates and leaves a clear supernatant liquid which gives no further preeipitate on the addition of a few drops of the reagent. In ease the eoagulation does not take plaee so as to furnish a clear liquid and one that filters easily, the whole should be 
thrown out and a more dilute solution of the tannin material taken. When precipitation has taken place satisfactorily, the mixture shonld be rapidly poured on two counterpoised filters placed one inside the other, the preeipitatc washed with just sufficient warm water to remove alum, dried at $110^{\circ}$, and weighed. For gallotannic acid 54 per cent. of the precipitate should be considered tannin. With the amount of alum above mentioned it is possible to add the gelatin solution in slight excess without dissolving any of the precipitate.

According to Johanson 100 parts of gelatin preeipitate 120 parts of dry tannin.

Schulze recommended the use of ammonium chloride to cause eoagulation of the precipitate; his solution contained ten grammes of gelatin in one litre saturated with ammonium chloride, and Löwenthal used a saturated solution of common salt with one-tenth its volume of hydrochloric acid (specific gravity 1.120) for the same purpose, but, if the proportion of alum (10 grammes to 1 litre) recommended above be used and the details carefully earried out, it will be found preferable.

Powdered or rasped raw-hide was originally suggested by Davy and more recently used in the proeess of Hammer. This method eonsisted in preparing a solution of the tannin matcrial, taking its specific gravity, then digesting it for a few hours with hide to four times the supposed amount of tannin present, which latter should be present to the extent of from 3 to 5 per cent., filtering, and again taking the specific gravity. The loss in spccific gravity on aecount of digesting with hide represented the tannin, a loss of .0040 indicating one per cent. 
There are many sources of error in this process, as has been pointed out by Rau, who says, "A 5-per-cent. solution of gallotannic acid had a specific gravity of 1.01841. The density of distilled water being 1.0000 , the 5 per cent. gallotannic acid was represented by the increase in specific gravity 0.01841. A solution of canesugar was prepared having specific gravity 1.01646, and 5 per cent. of the same gallotannic acid dissolved therein. The specific gravity of the latter solution was then found to be 1.03398 ; consequently the same percentage of tannin was in this case represented by a somewhat smaller increase in specific gravity, 0.01752." The same author by expcriments showed that the coloring-matters of logwood and Persian berries were largely absorbed by the hide powder along with the tannin.

Simand recommended the use of bone tissue instead of hide powder. This bone tissuc he prepared by taking tubular bones free from joints, macerating them for two days with a five-per-cent. solution of soda, thoroughly washing with water, reducing to smaller pieces, and treating with dilute hydrochloric acid until softened, then washing and passing through a grinding machine while still wet. This comminuted mass was treated with dilute hydrochloric acid, thoroughly washed, pressed, and dried.

Simand and Weiss estimated the tamnin in extracts by hide powder, which they prepared from fresh skin by washing, unhairing, treating with dilute hydrochloric acid, stretching, and drying. 'The skin was then planed fine, dricd, and worked through a fine sieve. The watery residue from 5 grammes of this powder 
gave only 0.036 gramme dry residue, eontaining 0.008 gramme ash.

In order to estimate a sample of taunin extract, from 12 to 16 grammes of a solid or 22 to 28 grammes of a liquid sample were taken, dissolved in distilled water, made up to one litre, and filtered ; 100 ee. were evaporated to dryness, dried, and weighed, thus giving the total amount of soluble matter ; $250 \mathrm{ec}$. of the solution were placed in a dry flask with one gramme of hide powder and shaken for two hours, then filtered into another flask and this treatment with one gramme of hide powder twiee more repeated, and then a fourth time with 2 grammes of hide powder. This quantity (5 grammes) was eonsidered quite suffieient to extraet all tanning material. The solution was then filtered for the fourth time and $100 \mathrm{ec}$. evaporated and dried. The differenee between this weight and that obtained by the first evaporation indieated the amount of tannin.

Bone tissue as well as hide powder is available for this proeess, which has many points of value, and, if the eorreetion for the solubility of the hide powder or bone tissue could be aeeurately made, it would be the most satisfaetory and exaet of the numerous methods that have been proposed. In aetual practice, however, it has been found almost impossible to get a gelatinous tissue that is not somewhat soluble in water, whieh solubility should be addled to the amount of tannin found, but, as most of the soluble portion is eapable of being preeipitated by tannin, it is not proper to add the whole amount of tissue whieh is dissolved by water, therefore the eorreetion is an unknown quantity, and, 
unless a gelatinous tissue can be made that is eompletely insoluble in water, the process is not available.

Muntz and Ramspacher contrived an apparatus for use in Hammer's method, which consisted of a press so eonstructed that the tannin solution could be forced through hide, the specific gravity taken before and after, or a portion of the liquid evaporated in each ease. It, however, had no advantages over the original method, and has been used but little.

4. Under the fourth class of methods we have practieally one in which the use of potassium permanganate is combined with the gelatin or hide method. The use of caleium hypochlorite has been suggested to replace the permanganate, but with no apparent advantage.

Monier in 1858 first proposed the use of potassium permanganate for volumetrieally determining the amount of tannin by adding the reagent until the solution assumed a pinkish color. It was soon found, however, that tannin was not the only substance oxidized by permanganate, and in infusions the color interfered with the determination of the end reaction.

In 1860, Löwenthal rendered the process more available by suggesting the use of indigo as an indicator, which at the same time controlled the oxidation, and this he further greatly improved in 1877 by combining the gelatin process with it, making a permanganate valuation, before and after treatment with gelatin. Neubauer in 1871 suggested a similar improvement, using animal chareoal instead of gelatin.

The permanganate method, with further improvements by Proeter, Hunt, Von Schröder, Couneler, and others, has come to be regarded as the standard process 
of the present time, although it is not without its faults, and is especially difficult for one who only occasionally desires to make a tannin assay.

In 1883 a Commission of German technical chemists was appointed to meet in Berlin and report on a method of tannin assay. This Commission consisted of Dr. C. Councler, Dr. J. v. Schröder, and Messrrs. A. Eberz, Franz Kathreiner, Schaun, and F. Simand. W. Eitner, of Vienna, was prevented from taking part in the proceedings. In two years they presented a report, under the title of "Bericht über die Verhandlungen der Commission zur Feststellung einer einheitlichen Methode der Gerbstoffbestimmung, Cassel, 1885. Verlag von Theodor Fischer." In addition to the reeommendations, this report contains a critical investigation of the Löwenthal method by Dr. von Schröder.

The following process will give that recommended by the Commission, together with some improvements that have been suggested by various investigators since. Although far from perfect, it may be said to represent fairly the mothod of to-day, and is capable of giving satisfactory results in competent hands.

Briefly outlined, the process, which is still known as Löwcnthal's, consists in taking a dilute solution of potassium permanganate, determining the amount of it necessary to decolorize or change to yellow a given amount of indigo solution, and then the amount required to change the same volume of indigo solution and pure tamnin solution. Another portion of the tannin solution is then treated with gelatin or hide powder, filtered, and portions of the filtrate and indigo which represent the same amounts as were previously 
treated witlı permanganate are again decolorized by that reagent. The difference in volume of permanganate solution used before and after treatment with gelatin gives the amount of permanganate required to oxidize this known amount of tannin.

This tannin solution can then be replaced by an infusion which represents a known quantity of tannin material, and the percentage readily calculated. The indigo serves as an indicator and at the same time controls the oxidation; since it is decolorized with some difficulty, it indicates that the other substances have all been oxidized when the blue color disappears.

\section{SAMPLING AND PREPARATION OF THE TANNIN INFUSION.}

From 500 to 1000 grammes are so taken as to represent the whole eargo. This sample is then ground in a drug-mill or powdered in a mortar until all of it will pass through a sieve of 20 meshes to the ineh. It is not sufficient to discontinue the grinding when enough has been obtained to furnish 10 or 20 grammes for the infusion, but the whole 500 or 1000 grammes must be ground, sieved, and then thoroughly mixed before proceeding, since the first portion ground is much softer than that reduced last, and therefore represents a different amount of tannin. After all has been ground, sieved, and thoroughly mixed, 5 grammes of galls, 10 grammes of sumac, valonia, or myrobalans, or 20 grammes of bark are boiled for one-half hour with 500 ce. of water, strained into a litre flask, and washed and pressed with sufficient water to bring the measure of the infusion to one litre. 
As glass is liable to fracture in the above boiling, a kettle of what is known in this eountry as "agateware" has becn found very satisfactory. The infusion may also be prepared in an apparatus described by Von Schröder (Fig. 1), which eonsists of a cylindrical

FIG. 1.

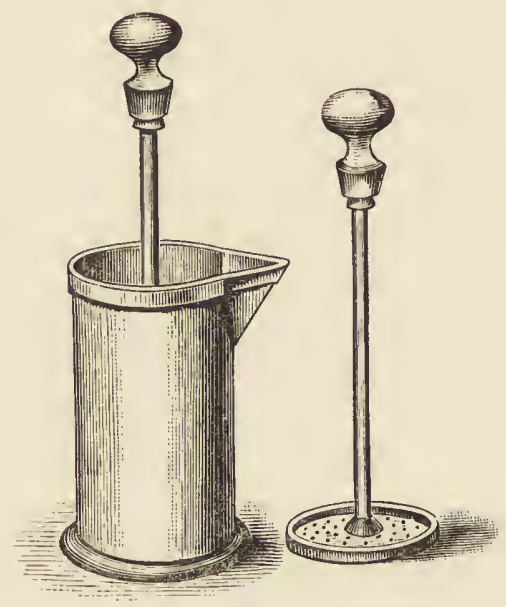

cast-tin vessel $12.5 \mathrm{~cm}$. high and $7 \mathrm{~cm}$. in diameter, with a spout but no handle; the latter is omitted in order that the sessel may be more readily heated in a water-bath. Accompanying this is a strainer or plunger of the same metal, with a handle about $16 \mathrm{~cm}$. in length. The strainer is of such diameter that when eovered with muslin it will just fit the inside of the cylindrical vessel and play the part of a piston to it. Five, ten, or twenty grammes of the powdered material are plaeed in the vessel, 200 ec. of cold distilled water added, and, 
after maccrating for one hour, the strainer is pressed into the cylinder and the solution poured into a litre flask. The strainer is then drawn up, and, without removing it, $200 \mathrm{cc}$. of hot distilled water are poured in so as to wash the liquid and powder adhering to the strainer down into the vesscl, which is immediately set in a water-bath and heated for one-half hour, the strainer pressed down, and the solution poured into the litre flask. This operation of hot extraction is continued until 1000 cc. of infusion are obtained; it is then allowed to cool, cold water is added to bring the solution again up to the mark, and the whole is filtered. The tannin strength of the solution should be such that $10 \mathrm{cc}$. will not reduce more than $8 \mathrm{cc}$. of permanganate solution.

It is sometimes desirable to distinguish between the easily soluble tannin and the difficultly soluble tannin. That which dissolves in cold water is accepted as representing the former, while that which is afterwards removed by hot water represents the latter. The infusion of these may be prepared by extracting in the Von Schröder apparatus with cold water until one litre is obtained, and then preparing a litre of the hot infusion from the residual material.

It was suggested by the Commission to employ a Real's press for the cold extraction of the tannin material. This consists of a closed cylindrical percolator of metal so arranged as to allow the water to be applied under the pressure of a column one and onc-half metres in height.

The accompanying illustration (Fig. 2) is of an apparatus which may be constructed in any laboratory, 
DETECTION AND ESTIMATION OF TANNINS. 47

FIG. 2.

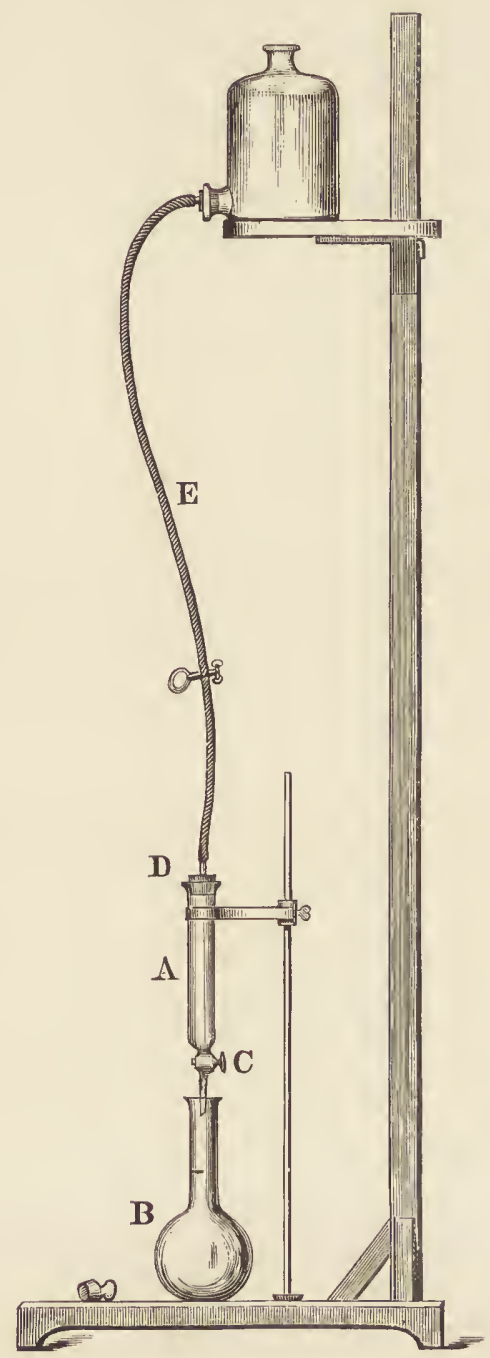


and will accomplish the purpose nnder any reasonable height of water column. This consists of a glass percolator, $A$, fitted with a stopcock, $C$, at the lower end, and with a tightly-fitting rubber stopper, $D$, at the top; to a glass tube in this cork is attached a rubber tube, $E$, of any desired length, and connected with a small reservoir, that is arranged to be placed at variable hcights above the pereolator, and at the lower orifiee of the latter is placed the litre flask $B$. The sample is packed in $A$ and eold distilled water run on until it begins to drop from the lower cnd, the stopcock $C$ is then closed, and under a pressure of a column of water onc and one-half metres in height it is allowed to maeerate for from twelve to sixtecn hours; the stopcock is then opened, and the percolation allowed to proceed until one litre of liquid is obtained. The liquid should not be allowed to come from the percolator faster than in drops, and to obtain one litre should require from three to four hours. It is just as well to have a pinchcock attached to the rubber tube $E$ to assist in controlling the flow of liquid. When the desircd amount of cold infusion has bcen obtained, the residue is extracted with hot water in a Von Schröder apparatus or any other convenient vessel in order to obtain one litre of the hot infusion.

THE ASSAY OF THE TANNIN INFUSION.

For this part of the operation the following apparatus and ehemicals are required.

1. Permanganate Solution.-Ten grammes of pure potassium permanganate are dissolved in 6 litres of water. 
2. Indigo Solution.-A solution of 30 grammes of sodium sulphindigotate ("Carminum cœrul. opt., pure Indigotin I. of Gehe and Co.," Dresden) in 3 litres of dilute sulphuric acid (1 volume of the acid to 3 volumes of water). This is agitated for some time, filtered, and sufficient water added through the filter to make 6 litres. The value of this solution should be such that 20 ce. in $750 \mathrm{cc}$. water should require about $10.7 \mathrm{cc}$. of the above permanganate solution to decolorize it.

3. Hide Powder.-This must be white and woolly in character, and not yicld to cold distilled water any substance capable of reducing permanganate. Such a powder is prepared by Dr. Roth, of Berlin, and by the Vienna Rescarch Station, and can usually be had of importers and dealers in chemicals throughout the world.

4. Standardizing the Permanganate Solution.-The purest obtainable tannin (that of Schering was recommended by the Commission) is used for the standard. For this purpose a portion is dried at $100^{\circ}$ to constant weight, then such a quantity of the air-dried substance as to represent 2 grammes of it in the dried condition is taken and dissolved in onc litre of water.

$10 \mathrm{cc}$. of this solution and $20 \mathrm{cc}$. of the indigo solution are added to $750 \mathrm{cc}$. of watcr, and the permanganatc solution is run in from a graduatod burette with constant stirring until the liquid assumes a grcenish color, and then more cautiously, a drop or two at a time, until a pure yellow color with a pinkish rim is reached, which is most apparent on the shaded side. $50 \mathrm{cc}$. of the tannin solution are then macerated with 3 grammes of hide powder (which has been previously well moistened and 
squeezed out) for eighteen or twenty hours with frequent agitation, filtered, and 10 ee., with 20 ec. of indigo solution in 750 ee. of water, titrated with the permanganate as before. The differenee between the amount of permanganate in the first and seeond titrations represents the tannin or oxidizable matter removed by hide. The "not tannin," or oxidizable matter not removed by hide, should not much exeeed 5 per cent.

The titration is best earried out in a porcelain dish, althongh a beaker-glass on a white surfaee may be used.

Having the value of the permanganate in tannin, we next take the infusion prepared as previously described and earry out the titration with permanganate and treatment with hide on it, by using 10 ee. of the infusion, 20 ec. of the indigo solution, and 750 ec. of water. After obtaining the permanganate value of this infusion, $50 \mathrm{cc}$. more of the latter are agitated for from sixteen to eighteen hours with 3 grammes of hide powder as before, and 10 ec. of the filtrate titrated in the presenee of 20 ee. of the indigo solution and 750 ee. of watcr. From these data it is easy to caleulate the pereentage of tannin in the material from which the infusion was made.

Von Sehröder found by the use of Hammer's method that the purc tannin does not represent the fill value of the tanning material, and snggester that the tannin found be multiplied by 1.05 .

Nenbauer used animal ehareoal instead of hide powder for absorbing the tannin; it has been found, however, to absorb other substanees than tannin in eonsiderable quantity. 
Löwenthal used a solution of gelatin instead of hide powder. This solution was prepared by taking 20 grammes of good gclatin, allowing it to swell for several hours in cold water, then dissolving with the aid of heat and more water, saturating the solution with common salt, adding $100 \mathrm{cc}$. of hydrochloric acid and sufficient water to make one litre. The infusion after agitation for some time with the gelatin solution was found to filter slowly, and Procter suggested stirring in about 5 grammes of finely-powdered kaolin for causing a rapid settling of the precipitatc and so giving a solution which filtered rapidly and clear.

Simand recommended the bone tissue previously described.

Many more details and numerous suggestions of minor importance might be added, but they would serve rather to complicate the process given. To those who wish to study the original papers on tannin estimation more in detail, the following are recommended: Gauhc, Cech, Löwenthal, Ncubauer, Proctcr, Nötzli, and the Report of the Commission of German chemists. 


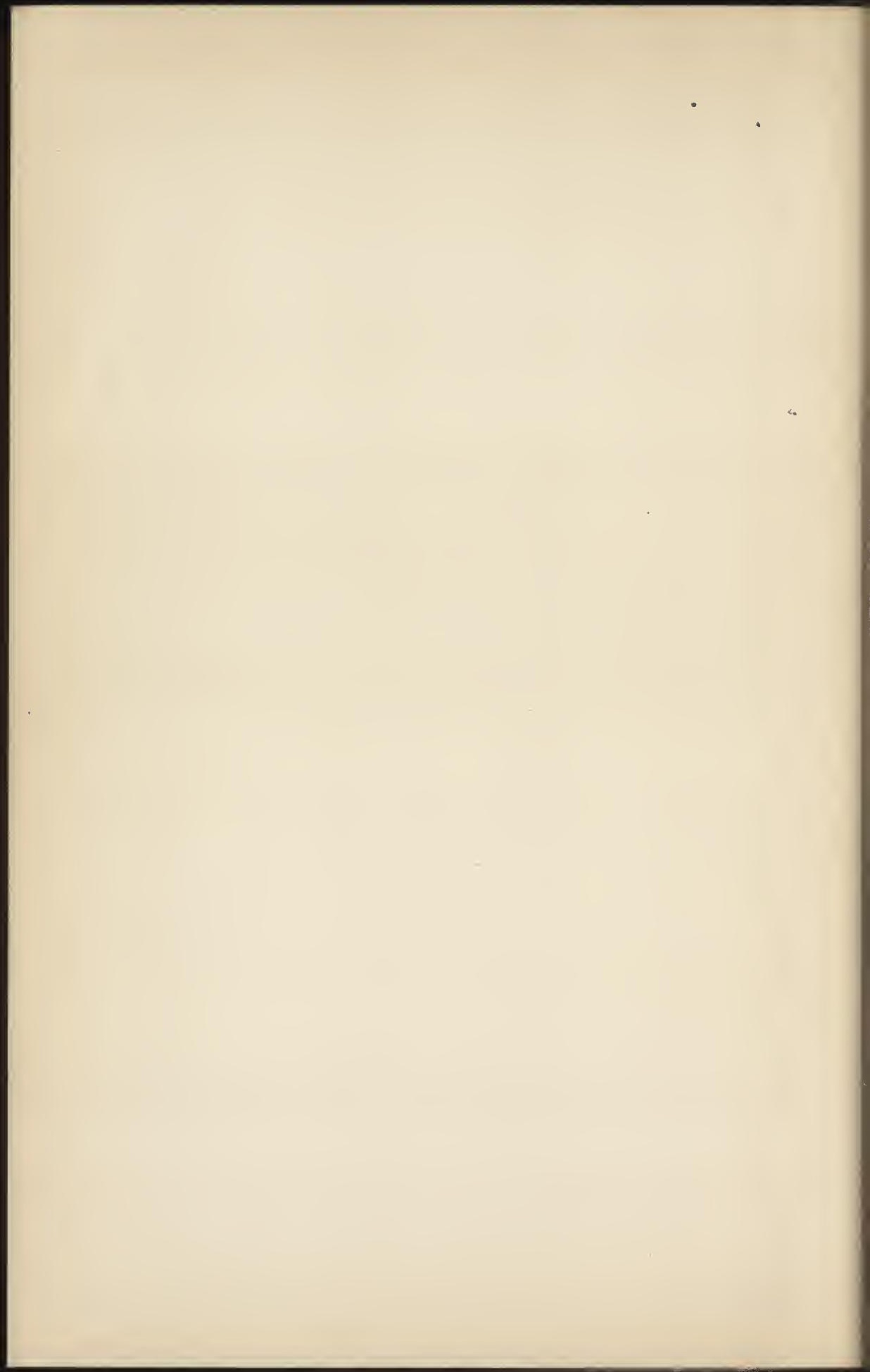


PART II.

GALLOTANNIC ACID. 


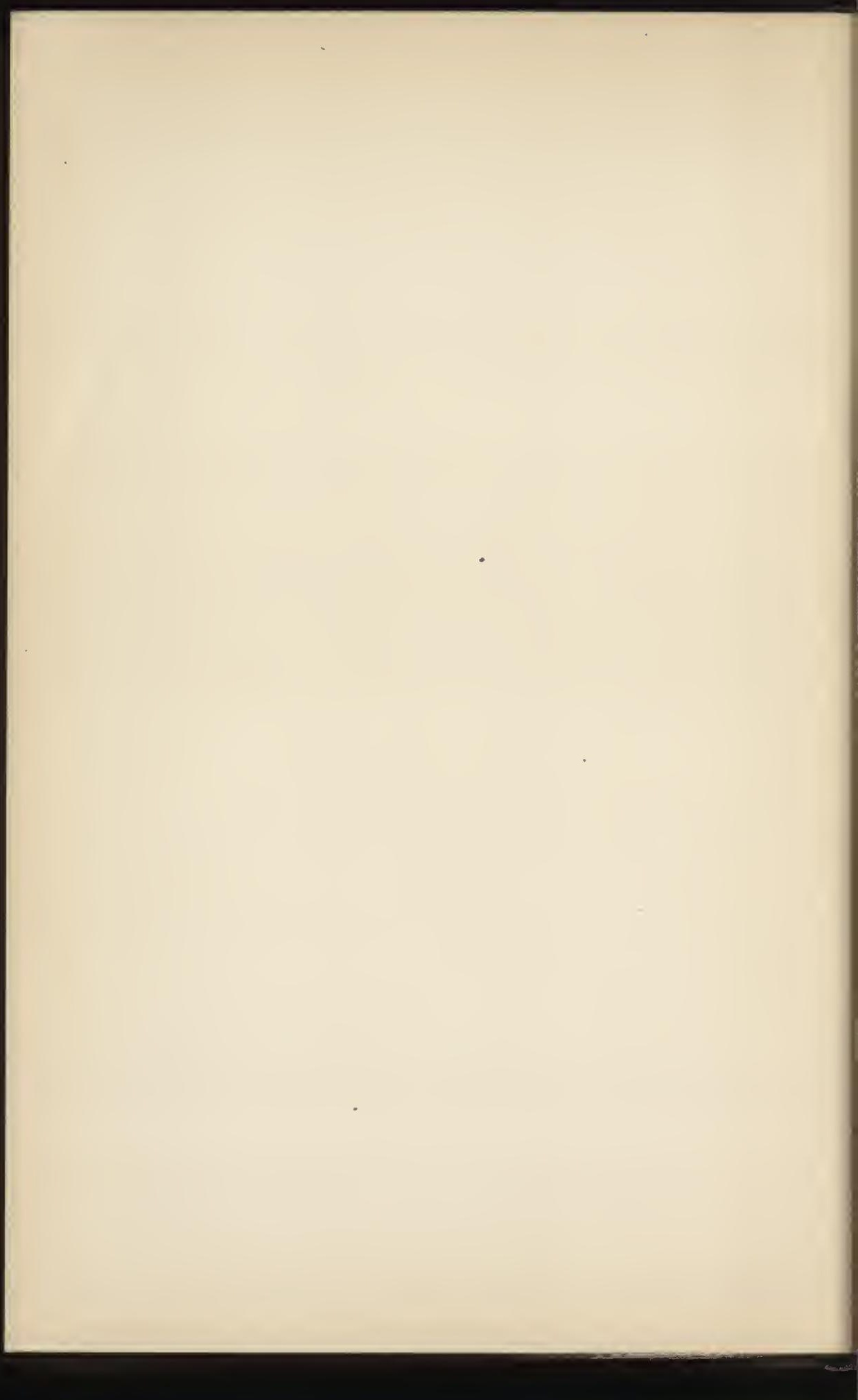




\section{SECTION I.}

\section{SOURCES.}

By the puncture of a small insect, the Cynips Gallx tinctorix, on the young buds of the small twigs of Quercus lusitanica, variety infectoria, there are deposited ova, around each of which rapidly forms a mass that in its perfected state becomes the gall, oak-gall, or nutgall of eommerce. The small tree or shrub which furnishes these galls grows chiefly in Asia Minor and some of the other regions surrounding the Moditerranean Sea.

The early history of galls is conveniently assigned to the ancients. Hippocrates administered them medicinally, and from the earliest times they were resorted to as a means of staining the laiir black. Theophrastus, Dioscorides, Pliny, and other writers mention the superiority of the galls from Syria.

The most esteemed galls at the present time are those collected in Mesopotamia and shipped from Bombay to London. They are known in commerce as Levant galls. The best-known variety in this country comes under the name of Aleppo or Turkish galls. They are collected in the surrounding districts and taken to Smyrna, where they are sorted and shipped to various 
parts of the world. Poorer varieties are shipped from some other Mediterranean ports.

Galls are nearly globular, from ten to twenty millimetres in diameter, tapering slightly towards the base, the lower half being smooth, while the upper portion is usually covered with numerous bluntly-pointed tubercules. The best galls are gathered before the insect has matured; if left until after this development has occurred, there is found about half-way between the stem and summit a small hole, from which the developed insect has escaped; at this period they are found to be deficient in tannin, and therefore become the green or white variety. Those collected at the proper time are heavy, somewhat brittle, breaking with a slightly resinous fracture, exhibiting the larva in a small eavity at the centre, while the surrounding tissue frequently appears as a radiating structure. Internally galls are deep greenish yellow, without odor, of a slightly acid and very astringent taste with a faintly sweetish aftertaste.

When Scheele in 1786 discovered gallic acid he supposed it to be the most important constituent; Chevreul afterwards found ellagic acid; then Schcele produced pyrogallic acid, and supposed it identical with. gallic acid, but much purer, on account of having becn sublimerl; then followed the work of Dizé, Deyeux, Seguin, and Proust, as stated in the preceding general history.

After the existenee of tannic acid was well established, Davy in 1803 appears to have been the first to make an analysis of nutgalls, with the following result : 
Tannic acid . . . . . 26.00 per cent.

Gallic acid ....... . 6 6.20 "

Gum and insoluble tannin ... 2.40 "

Calcium and other salts . . . . 2.40 "

Woody fibre......... 63.00 "

$\overline{100.00}$ "

These figures indicate either that the quality of the galls was poor, or, more probably, that the methods in use at that time were defective.

A more recent analysis was made in 1845 by Guibourt, with the following result:

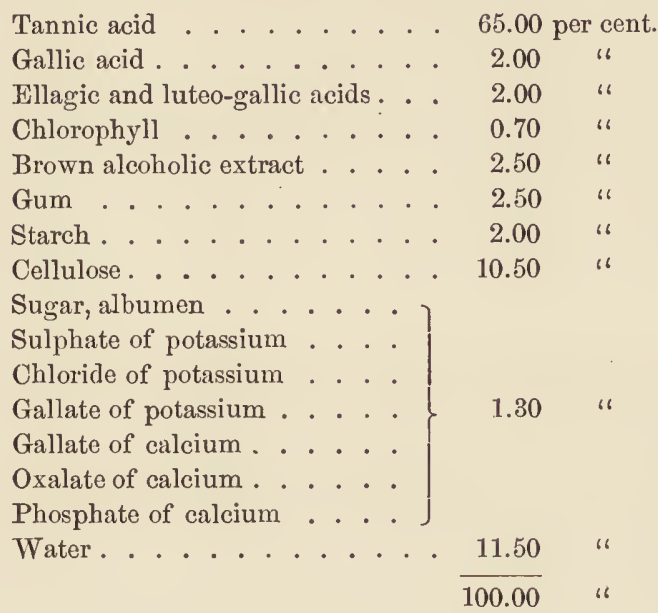

These results have been generally accepted, and are universally quoted in text-books, as no chemist since then has attempted such a detailed analysis. It may with reason be doubted if an analysis at the present time would agree in all points with this one.

A still more recent, although not intended to be so 
complete an examination was made in 1869 by Watson Smith, for the purpose of comparing English and Aleppo galls :

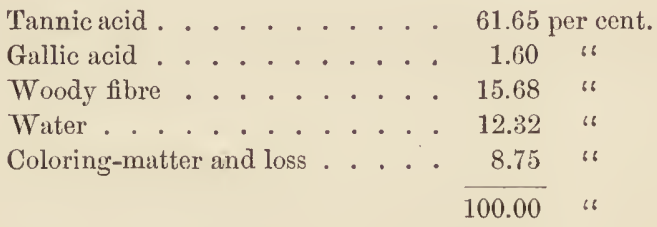

Another variety of galls, which for some purposes rivals the Turkish in importance, is that from China. These are formed by an insect, Aphis Chinensis, on the leaf-stalks and young branches of Rhus semialata, a tree from ten to fifteen metres in height, indigenous to North India, China, and Japan. Chinese galls are hollow, from two and a half to four centimetres in length and half that measure in breadth. They are frequently quite irregular in shape, with horn-like projections. The shell, which eonstitutes the material part, is thin and brittle, breaking with a resinous fracture. The external surfaee is grayish or mouse-colored and eovered with a fine velvety pubeseenee.

Closely allied to these are the Japanese galls, which are so similar as to lead one to believe they are the same. They have, however, been assigned by Sicbold to Rhus Japonica and by Murray to Rhus javanica. Being more deeply lobed than the Chinese variety, they are consequently more irregular in form.

Although the Japanese galls are preferred by some, the two varieties are usually employed indiseriminately. Large quantities of both under the name of Chinese 
galls are used in Germany and the United States for the manufacture of tannic aeid, of which they contain about 70 per eent. They were received in Europe as early as 1817, when they were analyzed by Brande, who stated that they yielded to eold distilled water 75 per cent., and to alcohol the residue gave an additional 4 per cent., leaving 21 per cent. of woody fibre.

It was not until 1844 that these galls were reegnized to be of any value, so that our knowledge of their constituents dates from that time. The Japanese varicty was first brought prominently to notiee at the Paris Exposition in 1878.

W. Stein in 1849, under the name of a new kind of galls, described the Chinesc variety as having the odor of tobaeeo and yielding 2 per cent. of ash, consisting of potassium, magnesium, calcium, and iron combined with phosphoric, silicic, and earbonic acids and chlorine. The other constituents were given as follows:

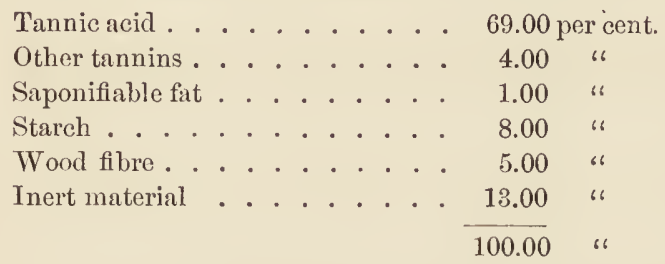

L. F. Bley in 1850 found that ether dissolved 76 per cent., that moisture amounted to 8 per cent., and that the ash was alkaline, nearly free from calcium salts, but rich in potassium and phosphoric aeid. Büehner in 1851 stated that ether-alcohol extracted 74.35 per cent., while Leconnet obtained by maceration with ether 66.66 per cent. 
Büchner considered the tannin identical with that of oak-bark. In comparison with the above he found that Aleppo galls gave to

Ether . . . . . . . 77.00 per cent. of extract.
Ether-alcohol . . . . . 80.40 "
Cold water . . . . . . 86.50 "

Under the commercial name of "Chinese pear-galls," Hartwich in 1875 described a species of galls, which he found to contain 72 per cent. of tannin. He was unable to ascertain the botanical sourec, but they probably belonged to one of the above varieties.

A number of other varieties of galls have been analyzed and described from time to time; their use, however, has usually been eonfined to the locality in which they grow.

Among these may be mentioned the Bassorah, Burmah, or Mecea galls, which were analyzed by L. F. Bley in 1853, with the following results :

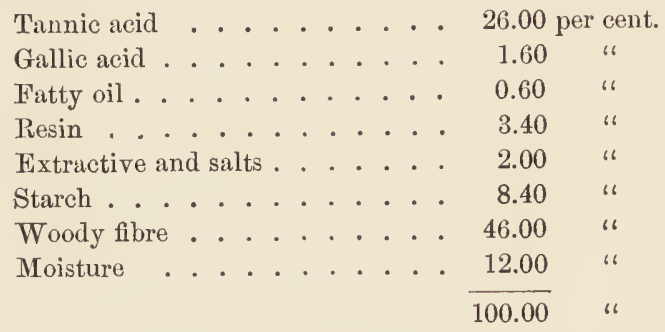

They were described as reddish-brown in color, from the size of a hazel-nut to that of a small apple. They were believed to be produced on the Quercus tinctoria by the sting of Cynips isana, and by Lambert were 
considered identical with the "Sodom Apple" of the ancient writers. They were used in the Orient in the process of dyeing Turkey red.

Piedmontese galls are developed on the aeorns of Quercus pedunculata, Quercus sessiliflora, and some other species, by the sting of the Cynips Quercus-calycis. They are known as knoppern or acorn-galls. These galls, which are of the size of a hazel-nut to that of a walnut, are eollected in the large forests of AustriaHungary from August to October, and are brought into commerce partly whole, partly in the powdered condition, and are either used directly in one of these forms or are converted into extract. They contain about 45 per cent. of tannic acid, which, according to Löwe, is . identical with that obtained from other galls. Some authorities give 20 per cent., others 50 per cent., as the tannin strength of these acorn-galls, and, no doubt, they vary greatly in value according to the time of collection. They are largely used by the tanners throughout Austria.

The German galls are produeed on the twigs of Quercus robur, and are probably identical with the English galls analyzed by Watson Smith in 1869, with the following results :

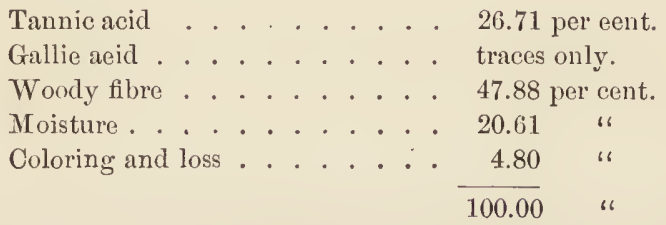

They were obtained directly from Cheshire, and the author suggested that the absence of gallic acid was 
due to their having been analyzed while in the fresh eondition.

Freneh galls, from Quercus ilex, are round, hard, light, reddish-brown, and related to the Burgundian galls from Quercus cerris, from whieh are also produeed the Greek as well as the Italian galls. The eommereial name of Trieste galls is usually applied to those from Q. cerris. Istrian galls are very small, light, pale yellow in eolor, and contain 24 per eent. of tannie aeid. Hungarian galls, from Q. Austriaca, are eharaeterized by being eovered with wart-like protuberanees.

Pistaeia galls are produeed on the plants of a genus - of that name, belonging to the same natural order as the Rhus. Guibourt deseribed one variety, produeed on a plant of the genus Terebinthus, as a flattened vesicle enlarged in the middle and tapering to a point at eaeh end, seven eentimetres long and seventeen millimetres broad, with a very astringent taste and an odor resembling Chio turpentine. Another variety produeed on the pistaeia was deseribed as from four to six eentimetres in lengtlı and eight to fifteen millimetres in breadth, terminating by a sharp point. The taste was deseribed as simply mueilaginous and aromatie without astringeney.

Tamarisk galls were deseribed by Holmes as of the size of a pea to that of a bean, and eontaining 40 perper eent. of tannie aeid. Those from Moroeeo are produeed on Tamarix articulata. In India similar galls are produeed on T. Gallica and T. orientalis. They are mueh used by the natives medieinally.

Numerous varieties of galls have been notieed in the 
United States, one from Texas on the Q. virens, or liveoak, is said to closely resemble Aleppo galls, and to eontain 40 per cent. of tannie acid. Another variety, from California, formed on Q. lobata, is soft and spongy but very astringent.

Dr. Squibb in 1873 stated that Ameriean galls from oak and sumac have been found valuable sources for gallic acid.

In 1890 galls collected in the vicinity of Philadelphia by the author from the leaves of $Q$. alba in the month of July, and identified by Mr. L. O. Howard, entomologist of the United States Department of Agrieulture, as having been produced by the insect Acraspis erinacei, were found to contain $\mathbf{1 7 . 8 9}$ per cent. of tannic acid. The moisture was found to be 45.95 per cent., and ash 0.60 per cent. Thesc galls are found most abundantly on the young white oaks, and may be recognized by their covering of purple spines. Another variety collected in August from the twigs of the same oak, and identified by Mr. Howard as "a Dipterous gall made by some species of Cecidomyia or Diplosis," was found to contain as an average of three estimations 9.34 per cent. tannic acid, 73.19 per cent. of moisture, and 0.46 per cent. of ash: The same variety rapidly dried by artificial heat at about $80^{\circ}$, so as to destroy the insect, yielded 31.68 per cent. of tamnin, 11.34 per cent. of moisture, and 2.6 per eent. of ash. Another variety, also collected in August, from the leaves of $Q$. palustris, and stated by Mr. Howard to have been produced by Holcarpis globulus, Fitch, gave 3.91 per cent. tannic acid, 58.73 per cent. moisture, and 0.77 per cent. ash. 
An unidentified variety, collected from the leaves of Rhus glabra, and in many respects the eounterpart of the Chinese galls, was allowed to become air-dried, and then found to eontain 61.70 per cent. of tamnic aeid, 12.93 per cent. of moisture, and 2.04 per cent. of ash. Some previous experienee has shown that the white-oak galls if allowed to become air-dried lose their tannic aeid, presumably by the development of the inseet, so that, to determine the tannin value, either the galls in the moist state must be employed, or they must be subjected to sufficient artifieial heat to destroy the inseet. 


\section{SECTION I I.}

\section{HISTORY.}

While the general history in a preeeding section refers largely to this member of the elass, it is found necessary now to treat the listory of each tannin separately, beginning with 1802, when Proust made the statement that there were many different kinds of tannin.

Davy published in 1803 the results of two years' labor on the subjeet, whieh was prefaced by some historieal remarks, in whieh lie, like Karsten, attributed the diseovery of tamin to Seguin, although he ealled attention to the faet that Dizé first noticed the precipitate caused by the addition of sulphuric acid to infusion of galls. He further reviewed the work of Deyeux and Proust, giving the former mueh eredit for his "able memoir," but to the elaim of the latter, "that there exist different speeies of the tanning prineiple, possessed of different properties and different powers of aeting upon reagents, but all precipitable by gelatin," he answered, that, while probable, it eould "not be considered settled until the tamnin in the different vegetables has been examined in its pure and isolated state." He did not aeeept all of Seguin's theories about the aetion of infusion of galls on animal membrane, and eonsidered them unwarranted by faets.

Thus far the papers quoted confined themselves to $6^{*}$ 
the history and discovery of tannin; therefore it is not surprising that in 1804 we find a contribution by Trommsdorff on the nature of this astringent principle in galls. His investigations somewhat resembled those of Deycux. The work was divided into fifty-five expcriments, in which he studied the precipitates causcd by hydroehloric and sulphuric acids on infusion of galls, and added the observation that acetic and phosphoric acids likewise caused precipitates with tannin, while oxalic, tartaric, and malic acids caused no precipitates. Hc noticed the effect of tannin solution, after removal of gallic acid, on litmus-paper, and further endeavored to obtain pure tannin by Proust's method of precipitation with potassium bicarbonate, but found much tannin in the filtrate, and finally concluded that the precipitate contained calcium and that Proust erred in his new method. The same conclusions were reached in regard to Proust's other methods by precipitation with mineral acids. This long, and at that time valuable, series of experiments was abruptly tcrminated without drawing conclusions, as he hoped to continue his investigations.

After the above communication no important results are recorded until Sertürner, an apothecary in Eimbeck, during the year 1812, published his experiments, in which he established the absence of nitrogen, and made some observations on the action of alkalics on tannin, and the change into gallic acid. As, however, his results were in part a repetition of those obtained by previous investigators, his work was not kindly criticised by Gehlen.

While there were a number of contributions on this 
subject from year to year, nothing stands out prominently until the work of Berzelius in 1827, whieh appeared in the Jahresbericht and in his text-book. After remarking that every investigator offered a new method of preparation, he proposed two of his own, one by prceipitating a clear infusion of nutgalls with sulphuric acid, and the other by a similar precipitation with potassium carbonate. At that time there was no distinetion between the tannin of the nutgall and that from the oak-bark, since both are described as "EichenGerbstoff," and further he stated that the "entire oak genus contains a tannin which appears to be identical." The change of tannin into gallic acid had not been fully investigated at that time; Berzelins observed that the question is whether gallic aeid is formed by the destruetion of tannin, or whether it results from the setting free of a substance with which it was in combination. He uscd the classification depending on the color with iron salts, and described as giving a blue color the oak, sumac, alder, bireh, and a few others, and as producing a grcen color that of cinchona, catechu, kino, fir, and pine. He also reported what was probably the first determination of the ultimate composition of tannin. The lead salt was used, and his conclusion was that $\mathrm{C}_{18} \mathrm{H}_{18} \mathrm{O}_{12}$ most nearly represented the formula of tannin.

This work of Berzelius is full of historical data, and many of his results are as true to-day as at that time. He gave the eredit of diseovery to Deyeux in the following language: "The operation of tanning was known to the ancients, but the substance which combined with the hide was first noticed by Deyeux, and 
afterwards with more exaetness investigated by Seguin. Proust endeavored to discover a method of separation."

In 1832, Geiger, by a series of investigations on tannin and the aetion of that substance on iron salts, eame to the following conclusions : (1) All tannins are identical, (2) the iron-green taunins become iron-black if the free acid present be nentralized by an alkali or by iron, and (3) the iron-black tannins by the addition of some acid, especially tartaric, beeome iron-green. Berzelius, however, did not accept this, and he stated in his Jahresbericht that he too had notieed this peculiarity of the tanuins with iron salts under different cireumstances, but attributed it to a play of eolors, since by standing a black precipitate separated.

In Buchner's Repertorium für die Pharmacie, 46, 316,1833 , we find a review of a prize essay by $\mathrm{A} . \mathrm{W}$. Buchner on the subject of "The most Recent Discovcries on Tannic Acid or the so-called Tannin (Gerbstoff)." This was written in answer to the following questions, offered in 1824 by the Harlem Royal Academy of Natural Sciences:

"Is the so-called tannin, which we extract from different plants, a true principle, or have we given this name to different plant prineiples which possess the general properties of astringency and of forming leather?

"By what means can we best extract these substances from the various plants in a state of purity, and how determine that they are unmixed and distinct?

"Which is the best and most ready method for preparing tanning materials from the charcoal of indigo and other vegetable substances with acid, and how 
far is this artificially prepared tannin distinguishable from the natural? Are not the two identieal substances?

"In case of arriving at a fuller knowledge of the different tanning substances, to what use are the various ones best adapted in tanning and manufacturing as well as in medicine?"

While the answers to these questions are full of interest, it is impossible to see that the knowledge of the subjeet was very materially advanced by the writer. Some of the questions are still unsolved.

The next important work was in 1834, when a memoir was presented to the Institute of Franee by Pelouze, which memoir was widely copied and appears to have caused a general awakcning anong the scientists of that day to a closer investigation of this almost dormant subject.

Probably the most important part of Pelouze's memoir was the new method proposed for preparing tannin. This proeess is the one usually quoted in the textbooks at the present day, and is well adapted for the extraetion of the tannin from a substanee as rich in it as nutgalls.

Briefly, it consists in extracting galls with ether containing some alcohol and water. The solution separates into two layers, the upper an ethereal one of gallie acid with some tannin, the lower an aqueous solution of tannin eontaining some ether. This aqueous solution on evaporation leaves a porous mass of tannin, which Pelouze claimed was quite pure.

This substance gave on drying at $120^{\circ}$ the following pereentage composition : 


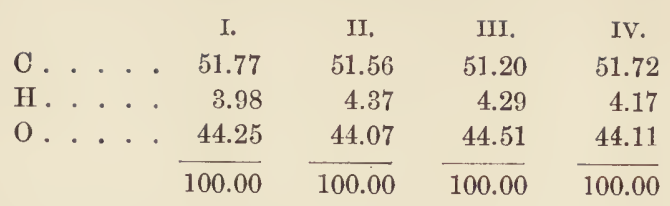

These figures, he stated, closely agreed with those obtained by Berzelius and indicated the formula $\mathrm{C}_{18} \mathrm{H}_{18} \mathrm{O}_{12}$.

The remainder of the memoir was devoted to showing the acid properties of the tannin and its capability to form definite salts with the different bases. He further stated that gallic acid did not pre-exist in the galls, but that it was a product of atmospheric action on tannin, that at a temperature of $215^{\circ}$ it was transformed into pyrogallic acid and carbon dioxide, and that pyrogallic acid in turn was converted into metagallic acid and water. This appears to have been the first statement, based on experiment, that tannin becomes converted into gallic aeid through the influence of atmospheric oxygen.

This work of Pelouze attracted general attention to the subject, and in the same year Liebig published his results on an elementary analysis in which he found:

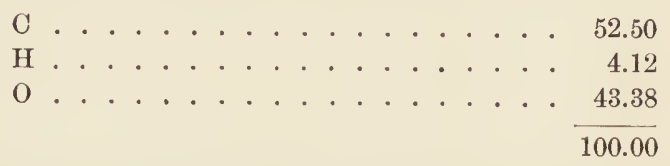

and coneluded that $\mathrm{C}_{18} \mathrm{H}_{16} \mathrm{O}_{12}$ more closely represented the formula. This he communicated to Pclouze, who undertook anew the analysis, obtaining the following percentage composition : 


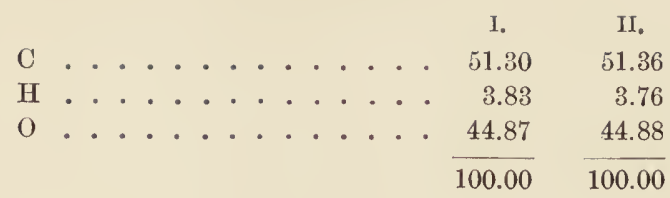

Thesc results he shortly after sent in a letter to Liebig, in which he stated that, whilc the difference was very slight, he was inclined to accept the latter's formula of $\mathrm{C}_{18} \mathrm{H}_{16} \mathrm{O}_{12}$, in whieh view Dumas eoncurred. With some unimportant reservations Berzelius, in his Jahresbericht, 1840, aecepted this formula also.

In 1836, Leeonnet suggested another method for preparing tannin, by stirring finely-powdered galls with sufficient ether to make a thin mixture, and allowing to stand twenty-four hours. The mass was then pressed between strong linen, this process was repeated with more ether, and the syrupy liquid evaporated. He claimed a larger yield (40 to 60 per cent.) than that obtained by Pelouze, with the use of much less ether.

Robiquet about this time directed his attention to the dccomposition of tannin with the formation of gallic acid. Contrary to the observations of Pelouze, he found that the change to gallic acid would take place without aecess of air or oxygen, but found it was caused by a ferment in the galls. These observations were eonfirmed by Larocque in 1841 .

Previous to the investigations of Stenhouse in 1842, sueh authorities as Pelouze, Berzelius, and Liebig considered the tannins from all sources to be identical, differing only in purity. Although Proust had stated forty years before that there probably existed "several different species of the tanning prineiple," Stenhouse 
was the first to prove this by experiment. In all the writings to this time the term "gallotannie acid" was applied to that from oak bark or wood as well as that from galls. Stenhouse, by adopting a method used at the present time to study the tannins, - namely, by heating to deeomposition,-found the oak-bark tannin yielded no pyrogallol. The only substanee yiclding true gallotannie aeid was found to be sumac, and this, so far as the sumae is eoneerned, has never been disproved. He also showed by experiment that there was a distinction between the tannins which produeed a blue and those whieh produeed a green precipitate with iron salts, thereby contradicting several previous investigators, as well as the expressed opinion of Berzelius. The subjeet of iron-bluing and iron-greening tannius attraeted eonsiderable attention about this time, and several other ehemists devoted their energies to solving the problem of elassification by this means, but with indifferent suceess.

The work of Domine in 1844 lias been very extensively quoted, beeause he offered some improvements on the method of Leeomnet for preparing tannin. He elaimed that aleohol was an unneeessary eonstituent of the ether used in extraeting galls, but that the presence of a small quantity of water was very essential. The method proposed was to allow the galls to beeome saturated with the damp atmosphere of a eellar by exposure of some days, then mix with sufficient ether to make a paste, and express, this expression to be repeated with ether whieh had been shaken with six per cent. of water. This proeess was at one time adopted by both the United States and British Pharmaeopoias. 
From this time those who worked with tannin busied themselves with attempting to arrive at its constitution as well as its composition ; Liebig's formula, $\mathrm{C}_{18} \mathrm{H}_{16} \mathrm{O}_{12}$, did not eonvey a suffieiently satisfactory idea of what relation tannin bore to other allied eompounds, especially to gallic and pyrogallic aeids.

A few investigators stand out prominently. Of these Wctherill first earefully investigated the conversion of tannic into gallic acid, by boiling 50 grammes of tannie acid with $500 \mathrm{cc}$. of a solution made by mixing one volume of sulphuric aeid, specific gravity 1.840, with four volumes of watcr. He obtained from 100 parts of tannic acid 87.4 parts of gallic acid.

About the same time, 1847, Mulder made a valuable eontribution on the subject. The original being in Dutch and in a publication not found in this country, a full translation may be found in Buchner's Repertorium für die Pharmacie, 101, 311, and Erdmann's and Marchand's Journal, 17, 337. Berzclins, Jahresbericht, 1850, 224, gave a sliort abstract of it, and appended some critical remarks of his own, which indicated that he did not believe this work of Mulder in any way superior to the great number of other publications on the subject.

Mulder stated in the introdnetory remarks that the formula of Liebig had been generally accepted, but that he found it to be $\mathrm{C}_{28} \mathrm{H}_{18} \mathrm{O}_{17}+\mathrm{H}_{2} \mathrm{O}$, which compactly stated in our nomenclatmre is $\mathrm{C}_{14} \mathrm{H}_{10} \mathrm{O}_{9}$, or exaetly that which has been cstablished by more recent investigators and is accepted at the present time. This determination was made on tannic aeid which had been dried at $120^{\circ}$. He gave much eredit to Pelouze, and stated that 
no better method of preparing the acid had since been discovered.

After further reviewing the work of Pelouze on pyrogallic and melangallic (metagallic) acids, he studied the conversion of tannie into gallic acid by the action of other acids; the action of alkalies on tannic, gallic, and cllagie aeids; the percentage composition of tannic acid and its formula; the action of ammonia; and, finally, some of the tannates, especially of lead.

With the exception of the work done by Liebig, it is safe to say that this work of Mulder was the most claborate investigation after that of Pelouze, which in many respects it resembled.

While there were about the year 1850 a number of creditable publications, nothing is of great historical value until we reach the work of Strceker in 1852 and 1854, which he carried out in Liebig's laboratory. These contributions are among the few that stand out prominently, for, besides reviewing some of the work of others, he detceted the presence of sugar, as had been previously indicated in Liebig's revision of Geiger's Handbuch der Pharmacie, edition of 1843, page 854, where it is stated that Braconnot found in the fermentation of galls alcohol and earbon dioxide, which indicated the presence of sugar, that had not been previously noted, and that tannic acid contained "the elements of six atoms of gallic acid and one atom of grape-sugar." Strecker had noticed that by heating tannic acid carefully a large carbon residue was obtained, when it had been previously supposed that the only decomposition products were pyrogallic acid and carbon dioxide. He also obtained the reactions for 
sugar in the solution remaining after converting tannic into gallic acid, by treating this solution with acetate of lead, filtering, removing the lead from the filtrate by hydrogen sulphide, and applying potassium hydrate and copper sulphate, whereby he obtained the reduction to cuprous oxide. This he attributed to the presence of sugar or a related carbohydrate. He further investigated the elementary composition of tannic acid and arrived at the formula $\mathrm{C}_{40} \mathrm{H}_{36} \mathrm{O}_{26}$, and he explained the change into gallic acid and sugar as follows:

$$
\mathrm{C}_{40} \mathrm{H}_{36} \mathrm{O}_{26}+10 \mathrm{H}_{2} \mathrm{O}=2 \mathrm{C}_{14} \mathrm{H}_{16} \mathrm{O}_{12}+\mathrm{C}_{12} \dot{\mathrm{H}}_{24} \mathrm{O}_{12} \text {. }
$$

These formulas were changed somewhat in his second paper, two years later, when he arrived at the following conclusions :

"Tannic acid is a glucoside, and is split, through the action of acids, alkalies, or ferments, into gallic acid and glueose.

"The formula for tannic acid is $\mathrm{C}_{54} \mathrm{H}_{44} \mathrm{O}_{34}$, in which three equivalents of water are replaced by metallie oxides. The precipitate obtained by acting on tannic acid solution with acetate of lead consists in great part of a basie salt in which are contained ten equivalents of lead oxide to one equivalent of tannie acid.

"The hitherto accepted compounds of tannic aeid with liydrochloric and sulphuric acids do not exist. acid.

"Gallic acid, $\mathrm{C}_{14} \mathrm{H}_{12} \mathrm{O}_{10}$, is, as tannic acid, a dibasic

"Other tannins are likewise glucosides, and contain apparently also thirty-four equivalents of oxygen."

The tannic acid used in these experiments was prepared by Pelonze's method, and purified in one casc by 
dissolving in water and precipitating with ether, and in another case by dissolving in ether and precipitating with water. By these operations different layers were obtained, the heaviest of which he considered the purest and scparated. 'These were then evaporated in vacuo and heated to $125^{\circ}$. Seven different preparations gave, when burned with copper oxide, closely agreeing results. He offered, as further evidence of the glucosidal nature of the acid, the fact that Wetherill obtained 87 per cent. of gallic acid and he found 22 per cent. of glucose.

Robiquet in 1852 arrived at somewhat different conclusions, but these were not backed by such a mass of experimental data as characterized Strecker's.

The work of Strecker might be a fitting close to the historical consideration, sinee the next important work brings us to such a modern period that it may be more properly studied under the properties and constitution of the acid.

The authors, however, should be mentioned in this connection ; therefore we must give to Julius Löwe and Hugo Schiff the credit of independently establishing by careful research our present knowledge of tannic acid. The former in 1867 first succeeded in reconverting gallic into tannic acid by treating barium gallate with silver nitrate and obtaining a substance which he described as precipitating gelatin and the alkaloids. His work was taken up by Schiff in 1871 and carried on for several years, and to this latter scientist we owe our present knowledge of digallic acid. It is worthy of note, however, as has bcen already stated, that most discoveries are in a certain degree anticipated, and this one of digallic acid was no exception, for Hlasiwetz in 
1867 announced that, "If tannin is not a glucoside, it may perhaps be a digallic acid. The analyses of tannin and its salts agree with this composition as well as can be expected in the case of a substance which is so difficult to purify."

Löwe in 1872 contributed a paper on pure gallotannic acid, in which he described a method of purification by acetic ether, which will be more fully considered under the appropriate head.

Notwithstanding the fact that most chemists at the present time devote themselves to the study of what may be termed artificial products, still those who have contributed to the literature of tannic acid during the last score of years could not be so much as mentioned in this brief history. During the past decade mucl time and earnest labor have been given to the endeavor to discover a universal method of estimating not only tannic acid but all tannins, and it is the intention that cach author shall receive his full share of credit in the other parts of this work. 


\section{SECTION III.}

THE PREPARATION AND PURIFICATION OF TANNIC ACID.

THE separation of tannic acid in a nearly pure state was first accomplished by Proust in 1798, by precipi-* tating the infusion of galls with stannous chloride, separating the tin from the precipitate by hydrogen sulphide, and evaporating the filtrate to dryness. This method, with its variation by using lead acetate in place of the tin salt, has done good service. The same in a lesser degree may be said of the process proposed by Berzelius, which consisted in precipitating the tannic acid by sulphuric or hydrochloric acid, digesting the precipitate, of tannic acid with the acid used, with lead carbonate, filtering, and evaporating to dryness. The above methods are not available for producing the acid on a large scale; and that by precipitation with lyddrochloric or sulphuric acid is applicable only to galls.

The numcrous processes for obtaining tannic acid from galls became practically valueless after Pelouze in 1834 published his metlod for obtaining the acid by percolating galls with ether. This method, which is the one usually quoted in the text-books, consists in percolating powdered galls with commercial ether containing alcohol and water.

The details of the operation are to pack the powder 
in a cylindrical percolator, the upper end of which is narrow in order that it may be stopped to prevent the evaporation of the solvent. The lower end of the percolator is plugged with cotton and connected with a flask, ether is poured on the powder, and the ethereal solution of the galls allowed to collect. This solution soon separates into two layers, the upper of which consists of ether, gallic and ellagic acids, resin, and fat, with some tannic acid, whilc the lower is a solntion of moderately pure tannic acid in water and ether. The percolation is discontinued when the lower layer ceases to increase in volume. The two layers are then separated, and the lower one evaporated to dryness on a watcr-bath, by which means the acid is obtained in a porous mass.

There have been, since the publication of this process, numcrous modifications of it suggested, but the principle remains the same. The product is not absolutcly pure tannic acid, but a mixture of that compound with gallic acid, coloring-matter, resin, and glucose. It is, however, a process that is adapted to working with large quantitics, where there are facilities for recovering the ether.

In order to obviate using so much ether, many methods have been offered as superior to the above, notably onc by extracting with water and precipitating with lead acctatc. It is, however, a wasteful process and is difficult and tedious to perform.

Mixtures of alcohol, ether, and water in various proportions have been suggested for percolating galls, instead of the commercial cther alone. Four parts of ether and one part of alcohol have been recommended as the most suitable solvent, although thirty parts ether 
(specific gravity 0.740 ), four parts water, and one part alcohol (90 per cent.) also make a good solvent. Equally good is the United States Pharmacopœia ether (specific gravity 0.750), which is composed of seventyfour parts ether and twenty-six parts alcohol with a little water. Equal volumes of ether and alcohol have been recommended on account of the increased yield obtained; the product, however, is not so pure as that from a more ethereal solvent.

In 1836, Leconnet proposed a method for extracting tannic acid by mixing the powdered galls with sufficient ether to make a paste, allowing the mixture to macerate, then expressing through muslin, and repeating the process with more ether. The yield was found to be 60 per cent., and a comparatively small quantity of ether was employed.

The process as modified by Dominé in 1844 was adopted by the British and United States Pharmacopœias. This modification consisted in first exposing the powdered galls in a damp cellar for several days, to allow the absorption of moisture, and then macerating with commercial ether and expressing as in Leconnet's process.

It has further been suggested to extract galls in such a manner as to form three layers of the percolate. To accomplish this, 10 parts of coarsely-powdered galls are placed in a percolator and a mixture of 12 parts stronger cther and 3 parts alcohol poured on, and the mixture allowed to stand two days, when the pereolation is commenced and continued with the same mixture of ether and alcohol until 10 parts are obtained. The resulting percolate is mixed with one-third its 
volume of water, agitated well, and allowed to stand, when it will be found that three layers have formed. The under, watery layer contains nearly pure tannic acid, and is evaporated rapidly in a vacuum, which causes the acid to become porous. The upper layers are distilled to recover the ether-alcohol, and from the residue water cxtracts a small quantity of impure tannin. The last method can be recommended only where it is desired to obtain a pure acid without the trouble of additional purification, for if made from Chinese galls the product should be as purc as it is possible to get the acid in one operation. It is not available as a commercial process, on account of its expensiveness, since the quantity of solvent recommended is insufficient to completely extract the galls.

The above-mentioned processes have been enumerated in order to criticise them, and at the same time furnish information to those who wish to prepare tannic acid from galls on a small scale. The following will treat the subject from a commercial stand-point, and describe what has been a process for producing the tannic acid in quantity.

There are three varietics of the acid in commerce, known as-

Ethcr-tannin (the German Schaum-Tannin),

Alcohol-tannin,

Water-tannin.

The first is the one best known in this country, although one or both of the others may be had of importers and manufacturers under the name of "commercial tannin."

The Chinese or Japanese galls, on account of their grcater frecdom from coloring-matter and larger per- 
- centage of tannic aeid, are by the manufaeturer preferred to the Turkish variety.

The galls are first erushed and then passed through a mill whieh will powder by cutting rather than by grinding, so as to furnish a moderately fine powder that is not "balled" or "caked."

A quantity of the powder is then stirred, in a wooden or copper vessel, with sufficient water to form a concentrated aqueous solution, or this may better be accomplished with a more eomplete exhaustion of the galls by a battery of vessels or extractors in which the liquors are run from one to another until of proper strength. The temperature of the water is recommended to be from $40^{\circ}$ to $60^{\circ}$, although this varies with different manufaeturers. When the liquors have reaehed the proper strength, they are run into a large settling-vessel and allowed to eool and settle for twelve hours; especially is this neeessary if a higher tempcrature than that above mentioned has been used. From the settling-tub the liquor is run through a filter into a cylindrical copper vessel like a churn, in whieh are numerous paddles so attached as to be capable of slow and continuous revolution. To the liquor in this vessel abont one-fourth its volume of ether (spceifie gravity .750) is added. The mixture is then thoroughly agitated by means of paddles. The longer this operation is continued the better the product is supposed to be, and when eompleted the emulsion-like liquid is run into a settling-vessel and allowed to stand for from eight to ten days, at the end of which time the eomplete separation into two layers will be found to have taken place.

The upper; ethereal layer, which holds in solution 
resin, fat, coloring-matter, gallic and ellagic acids, is drawn off and the ether recovered by distillation. The lower layer, consisting of water, ether, tannic acid, and some impurities, is also run into a still and a portion of the ether recovered by distillation until the liquid reaches a syrupy consistence. After cooling, this liquid, which still contains some etler, is spread by means of a brush on plates of sheet tin, and the tin plates are placed for a moment on the hot steam-eoil, or flat iron surface heated with steam, and over the whole is placed a wooden box. The tannic acid almost immediately "puffs up" and dries, although this spongy condition is said to be materially assisted by passing over the acid a jet of dry steam, which softens it slightly and admits of its swelling still further. Considerable practice and dexterity are required in this operation, which exposes the operator to the vapor of ether unless great precautions are takcn. Excellent results have also been gotten by spreading the solution on plates of glass and placing them in a drying-oven heated to $110^{\circ}$, which may be so ventilated as to protect the operator.

The product is the ether-tannin, and should be nearly white and completely soluble in water and in alcohol.

The needle or so-called "crystal-tannin" is prepared as above, but, instead of spreading the solution on tin or glass, it is run throtgh small holes and allowed to fall in a very thin stream on a revolving hot cylinder of copper, from which the dried product is scraped in the needle form, which gives the jmpression of its being crystallized.

Aleohol-tannin is prepared by extracting the galls with diluted alcohol (50 per cent.) instead of water, care- 
fully filtering, reeovering as mueh of the aleohol as possible, and eompleting the evaporation in a vaeum. It is then broken into pieees which resemble rosin, and sent into commeree in that form, or it is first powdered by poreelain rollers, whieh opcration gives it a mueh lighter color. The product should be completely soluble in water, indicating its freedom from resin.

Water-tannin is extraeted similarly to the ether-tannin, but after filtering, instead of mixing with cther, the solution is run direetly into a vaeuum-pan and coneentrated to dryness. It usually eomes in eommeree in the powdered form, whieh operation is aceomplished similarly to the alcohol-tannin.

Purification.-Tannie acid prepared by the foregoing methods is eontaminated with fat, wax, resin, eoloringmatter, gallic acid, and glueosc. For most purposes the small amounts of these impurities are no objection, but at times the ehemist desires a produet free from more than traees of impurity, espeeially when the objeet is to determine its ultimate eomposition. The fat, wax, some coloring-matter, and the odorous prineiple may be removed by pereolation with petroleum ether.

A number of proecsses have been suggested for removing the other impurities, all of whieh, however, are attended with eonsiderable waste. One method is to take the best ether-tannin and treat it with stronger ether, to whieh just suffieient water is added to effect solution. This is best aceomplished by using 100 grammes of the tannie acid, $150 \mathrm{cc}$. of stronger ether, and 100 ee. of water. Three layers are formed, the lowest of whieh is a eonecntrated solution of nearly pure tannie aeid. Considerable loss oeeurs by this pro- 
cess, as the middle layer contains some of the acid, which, however, may be recovered by distilling the ether and water under reduced pressure. The upper layer consists of ether holding in solution resin, coloring-matter, and gallic acid.

Another method of purification consists in dissolving the acid in water almost to saturation, and allowing to stand to separate the resin and other.insoluble impurities. The clear liquid is removed by decantation, and therc is added to it a clear saturated solution of common salt, to this is added some solid sodium chloride in order to completely precipitate the acid, which is collected on a filter, dried carefully, and dissolved in a mixture of alcohol and ether, or in acetic ether. Löwe recommended to agitate the mixture after addition of salt with acetic ether. In either case the solvent is rccovered by distillation, the residue dissolved in water and agitated with ether, the latter separated, and the aqueous solution distilled on a water-bath to dryness under reduced pressure, which causes the acid to bccome light colored and porous. Glucose is the most tenacious impurity, resulting in part from the decomposition of the tannic acid during each purification.

The following process, a combination of some previously-proposed methods, has been used by the author with complete snceess, although, like other processes, it is attended with considerable loss, which, however, might in part be obviated if the quantity desired were sufficient to warrant it.

Ten grammes of tannic acid are dissolved in $200 \mathrm{cc}$. of water, and to the unfiltered solution a 10-pcr-cent. solution of lead acetate is added drop by drop with con- 
stant stirring until the preeipitate ceases to be granular, but is more milky in eharacter, ceases to settle, and is pure white in eolor, distinct from the yellowish color caused by the first drops of the reagent. The filtrate at this point will be colorless. It is important that the solutions be as dilute as the above mentioned, or else the precipitate of lead tannate will not carry down the coloring-matter with it. After filtration the precipitate is washed with sufficient water to bring the filtrate to the original volume. More washing than this is to be avoided, on account of the tendency of the precipitate to decompose.

The colorless filtrate, which contains free acctic acid, is agitated with $75 \mathrm{cc}$. of pure acetic cther and the latter separated; this agitation is to be repeated twice with the same volume of acetic ether ; the three portions are mixed and the ether recovered by distillation under reduced pressure to dryness. A light, porous, white tannic acid is obtained amounting to 41 per cent. of the original quantity. It contains gallic acid and has a pungent acetous odor; the aqueous solution of a portion of it, after the removal of the tannic acid by lead oxyacetate, gives no reaction with Fehling's solution for glucose. The tannic acid is further purified by dissolving in water, agitating the solution with stronger ether to remove gallic acid, and distilling the aqueous solution to dryness under reduced pressure. This is once more dissolved in ether with a little water, and again brought rapidly to dryness under reduced pressnre. The result is a pure white product which gives no reactions for gallic acid or glucose. A sample pre- 
pared by these directions when dried at $120^{\circ}$ gave the following percentage composition :

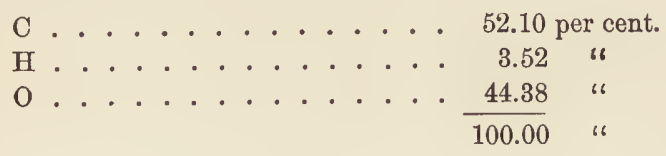

An acetyl derivative was prepared of the same sample which melted at $139^{\circ}$, and by boiling with magnesium oxide according to the usual process gave very close to the theoretical quantity of magnesium pyrophosphate that would indicate pentacetyl-tannin. 


\section{SECTION I V.}

\section{THE PROPERTIES OF TANNIC ACID.}

TANNIC ACID oceurs in yellowish-white amorphous powder or masses which are easily pulverized; it is odorless, and possesses a strongly astringent taste, free from bitterness. By exposure to light it beeomes yellow to brown in color.

It is soluble in 6 parts of water, in 6 parts of glycerin, and in 0.6 part of alcohol. The solutions are yellow in eolor, reaet acid with litmus, and are nearly without action on polarized light. Ether containing water $\mathrm{or}^{\circ}$ alcohol dissolves tannic acid, but absolute ether dissolves it sparingly, while it is insoluble in ehloroform, benzol, petroleum ether, carbon disulphide, fixed and volatile oils, except oil of bitter almond, which dissolves it.

A number of salts, as potassium acetate, ammonium chloride, calcium chloride, and sodium chloride, as well as the mineral acids, sulphuric, hydrochloric, arsenic, and boric acids, precipitate tannic aeid from its concentrated aqueous solution. Nitric acid does not so precipitate it. When air and light are excluded from the aqueous solution of tannic acid, it remains for some time without decomposition, but in contact with air oxygen is absorbed, with the formation of a dark color and the production of sugar, gallic acid, and sometimes 
ellagic acid; by prolonging this action carbon dioxide and oxalic acid also result.

When subjected to heat tannic acid changes but little until $120^{\circ}$ is reached, when it assumes a grayish color, without, however, undergoing apparent decomposition, at $140^{\circ}$ it is darker, and at from $160^{\circ}$ to $215^{\circ}$ there are formed carbon dioxide, pyrogallic acid, water, and netagallic acid. 'The last is not volatile, while the others are volatile; and this admits of a ready method of separating the meta-acid, which remains behind as a black, amorphous mass, from the pyro-acid, which sublimes in acicular crystals. Since the latter volatilizes at $210^{\circ}$, it is natural to suppose that, in order to obtain it from tannic acid, its volatilizing temperature must be reached; but it is found that the decomposition begins at $160^{\circ}$, and, in the escape of carbon dioxide and water, pyrogallic acid is carried off and condensed in the cooler parts of the vessel. The best yield is obtained by allowing the temperature to rise very slowly to $215^{\circ}$, keeping it between $190^{\circ}$ and $210^{\circ}$ for onehalf hour. If the heat be increased rapidly to $215^{\circ}$, there will be a small quantity of the pyro-acid and a larger amount of the mcta-acid produced.

On heating with a 2-per-cent. solution of absolute hydrochloric acid, tannic acid is converted into gallic acid :

$$
\mathrm{C}_{14} \mathrm{H}_{10} \mathrm{O}_{9}+\mathrm{H}_{2} \mathrm{O}=2 \mathrm{C}_{7} \mathrm{H}_{6} \mathrm{O}_{5} \text {. }
$$

The pure acid yields gallic acid only, but that usually met with gives variable amounts of glucose and ellagic acid at the same time.

With solutions of the alkalies gallic acid is formed, 
together with a dark color due in part to metagallic acid and in part, when commercial acid is used, to the action of the alkali on the glucose present.

Ammonia acts differently from the fixed alkalies. When tannic acid is heated with aqueous ammonia in an atmosphere free from oxygen, which is best accomplished by passing hydrogen into the mixture, there are formed gallamide and ammonium gallate, according to the following equation :

$$
\mathrm{C}_{14} \mathrm{H}_{10} \mathrm{O}_{9}+2 \mathrm{NH}_{3}=\mathrm{C}_{7} \mathrm{H}_{5} \mathrm{O}_{4} \mathrm{NH}_{2}+\mathrm{NH}_{4} \mathrm{C}_{7} \mathrm{H}_{5} \mathrm{O}_{5} \text {. }
$$

Fermentation causes the change of tannic into gallis acid, several decomposition products resulting at the same time.

Ferric salts produce a blue-black color or precipitate with tannic acid, according to the concentration of the solutions. When the solution of iron salt is very dilute, or when frce acid, especially tartaric, is present, the eolor is greenish.

Ferrous salts, when perfectly pure, added to tannic acid solution produce no change unless the solutions be concentrated, when a white gelatinous precipitate forms. The least trace of ferric salt is sufficient to change this to a dark-blue color or precipitate, according to the strength of the solution. Soluble vanadium salts also produce the blue-black color or precipitate with tannic acid.

Tannic acid precipitates most alkaloids and bitter principles. It gives a light-colored flocculent precipitate with gelatin, which is rendered more insoluble by alum, ammonium chloride, or sodium chloride; solutions of starch and albumen are similarly precipitated. 
Most metallie salts form preeipitates with tannic acid : tin salts produce a light-colored precipitate; lead salts, a white precipitate, which darkens on exposure to air; copper salts give a dark-brown precipitate; and silver salts, brown precipitates. Tartar emetic eauses no precipitate until ammonium chloride is added. Manganese acctate causes a white precipitate ; uranium acetate, a crimson or dark-red color, changing to a brown precipitate; potassium dichromate gives a brown precipitate; lime-water causes a white precipitate, turning blue.

According to Berzelins, when boric acid is dissolved in a hot solution of tannic acid, there is formed a white jelly on cooling, which may be dried to a white powder. Tannic acid displaces carbon dioxide from carbonates and forms tanuates; those of the alkalies rapidly turn dark when exposed to the air. Fehling's solution is redneed by tannic acid, with formation of cuprous oxide; in order, therefore, to determine the presence of glucose the acid must first be removed by lead acetate. A. H. Allen gives the following characteristic test for tannic acid : a dilute ammoniacal solution of potassinm ferricyanide, which causes a decp-red color changing to brown. The reaction is very delicate, and the color is destroyed by an cxcess of the reagent. A similar reaction is caused by gallic acid.

Ammonium molybdate gives with tannic acid a reddish-yellow color, which is destroyed by oxalic acid. A solution of iodine in potassium iodide, when mixed with a small quantity of ammonia which has been previously diluted with ten times its volnme of water, produces with"tannic acid a brilliant red color. 
Tannates are formed by addition of the acid to carbonates or hydrates in the case of the alkalies, and to hydrates in the case of the alkaline earths. With the metals it forms tannates on its addition to an acctate. By certain precautions the purity of the salt may be improved,-for instance, by the use of alcoholic solntions in the preparation of the alkali salts. Sodinm tannate, $\mathrm{NaC}_{14} \mathrm{H}_{9} \mathrm{O}_{9}$, and potassium tannate, $\mathrm{KC}_{14} \mathrm{H}_{9} \mathrm{O}_{9}$, are obtained as crystalline precipitates by adding an alcoholic solution of the hydrate to an alcoholic solution of tannic acid; the precipitate dries to a fine powder.

Barium tannate, $\mathrm{Ba}\left(\mathrm{C}_{14} \mathrm{H}_{9} \mathrm{O}_{9}\right)_{2}$, is formed by precipitating the sodium salt with barium chloride. Another barium salt, of the formula $\mathrm{Ba}(\mathrm{OH}) \mathrm{C}_{14} \mathrm{H}_{9} \mathrm{O}_{9}$, is formed by adding barinm carbonate to a hot aqueous solution of tannic acid.

At least three lead salts are known. According to Pelouze and Strecker, the compound $3 \mathrm{PbC}_{14} \mathrm{H}_{8} \mathrm{O}_{9}+$ $\mathrm{Pb}\left(\mathrm{C}_{14} \mathrm{H}_{9} \mathrm{O}_{9}\right)_{2}+2 \mathrm{H}_{2} \mathrm{O}$ is formed by precipitating lead acetate with an excess of tannic acid. Strecker is also authority for the componnd $2 \mathrm{PbC}_{14} \mathrm{H}_{8} \mathrm{O}_{9}+\mathrm{Pb}(\mathrm{OH})_{2}$ by precipitating tannic acid with an excess of lead acetate, and the componnd $\mathrm{Pb}_{3}\left(\mathrm{C}_{14} \mathrm{H}_{7} \mathrm{O}_{9}\right)_{2}+2 \mathrm{~Pb}(\mathrm{OH})_{2}$ by heating an excess of lead acetate with a dilute tannic acid solution. Schiff found two salts according as the tannic acid or lead acetate is in excess, an excess of the acid giving $\mathrm{Pb}_{2} \mathrm{C}_{14} \mathrm{H}_{6} \mathrm{O}_{9}+2 \mathrm{H}_{2} \mathrm{O}$ and an excess of the lead salt giving $\mathrm{Pb}_{3} \mathrm{C}_{14} \mathrm{H}_{4} \mathrm{O}_{9}$. The compounds with lead have probably been studied more than any of the other tannates, and many besides those given above have been described.

The tannates of iron have also received a large share 
of attention. The compounds $\mathrm{Fe}\left(\mathrm{C}_{14} \mathrm{H}_{8} \mathrm{O}_{9}\right)\left(\mathrm{C}_{14} \mathrm{H}_{9} \mathrm{O}_{9}\right)$ and $\mathrm{Fe}\left(\mathrm{C}_{14} \mathrm{H}_{9} \mathrm{O}_{9}\right)_{3}+\mathrm{FeO}\left(\mathrm{C}_{14} \mathrm{H}_{9} \mathrm{O}_{9}\right)$ have been described. All the tannates of iron are unstable, and we know them best in solution as ink. A compound of tannic acid with aluminium has been prepared by adding aluminium hydrate to tannic acid solution; the compound is soluble in excess of the acid. Zinc tannate is formed by precipitating an alkali tannate with zinc sulphate, or by adding the acid to ammoniacal zine sulphate. Copper tannatc, $\mathrm{Cu}_{3} \mathrm{C}_{14} \mathrm{H}_{4} \mathrm{O}_{9}$, is formed by precipitating the acid with copper acetate. When alkali is added the precipitate redissolves, and reduction to cuprous oxide takes place. Wackenroder is authority for the statement that, when the copper tannate which has been prepared by an excess of the acid is dissolved in ammonium hydrate, the copper is not precipitated therefrom on the addition of hydrogen sulphide.

Compounds of tannic acid with nearly every known metal are described in many of the text-books, but many of thesc salts were made by the older chemists before the acid had been prepared pure; conscquently, beyond the fact that we get insoluble compounds of a certain color, there is very little accurate knowledge concerning them. 


\section{SECTION V.}

\section{THE COMPOSITION AND CONSTITUTION OF TANNIC ACID.}

As stated in the history, numerous investigators in the first half of this century made cfforts to establish the composition of tannic acid. Mulder actually determined the formula, $\mathrm{C}_{14} \mathrm{H}_{10} \mathrm{O}_{9}$, accepted at the present time. It was not, however, until Lörve in 1867 prepared digallic acid by treating barium gallate with silver nitrate, and Schiff in 1871 studied the convcrsion of gallic into tannic acid by means of phosphorus oxychloride, that the foundation of our present knowledge was laid.

No better idea can be given of the importance of Schiff's work than by quoting portions of his papers. $\mathrm{He}$ first called attention to the fact that some chemists held the view that tannic acid was a glucoside, whilc others considered glucose to be an admixture, which varied much in its proportion, and that the bchavior of the acid towards reagents was not altered by the removal of the glucose. Schiff's method of forming digallic acid was as follows :

"When well-purified gallic acid dried at $110^{\circ}$ is mixed with phosphorus oxychloride to the consistence of an emulsion and heated in a water-bath at $100^{\circ}$ and afterwards in an oil-bath to $120^{\circ}$, there follows an abun- 
dant evolution of hydrochlorie acid. The gallic acid is converted into a yellow porvder, whieh is rvashed by decantation with several portions of absolute ether.

"The ether is removed from the residue by gentle warming and then dissolved in a small quantity of water. After twelve hour's' standing the gallic acid crystallizes out and is removed, and to the yellowishred solution is added sufficient common salt to saturate it, causing a separation of the resin-like mass, which is easily separated from the liquid and washed twice with saturated salt solution.

"The resin-like mass is dried under reduced pressure, dissolved in a small quantity of absolute alcohol, to remove salt, and to the clear alcoholic solution is added an equal volume of ether, filtered, the solvent distilled off, and the amorphous residue dried in a vacuum.

"The varnish-like, nearly colorless residue gives similar reactions, solubility, physical properties, taste, etc., which are eonsidered characteristic of tannic acid.

"It is the first absolutely sugar-free tannic acid."

The amorphous residuc was entirely reeonverted into gallic acid on boiling with hydrochloric acid, and this gallie aeid again converted into the amorphous acid by the phosphorus oxychloride.

Two elementary analyses gave the following:

$$
\begin{aligned}
& \text { I. II. } \\
& \text { C . . . . . . . . } 51.7 \quad 52.3
\end{aligned}
$$

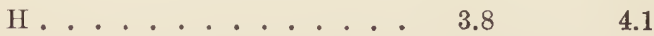

The question in regard to the nature of tannic acid was answered as follows: 
"Tannic acid is an alcoholic anhydride of gallic acid, very probably digallic acid."

This structural formula was at first suggested by Schiff :

$$
\begin{aligned}
& \text { Gallic Acid. } \\
& \text { Tannic Acid. } \\
& \mathrm{C}_{6} \mathrm{H}_{2}\left\{\begin{array}{l}
\mathrm{CO} . \mathrm{OH} \\
\mathrm{OH} \\
\mathrm{OH} \\
\mathrm{OH}
\end{array}\right. \\
& \begin{array}{l}
\mathrm{C}_{6} \mathrm{H}_{2}\left\{\begin{array}{l}
\mathrm{CO} . \mathrm{OH} \\
\mathrm{OH} \\
\mathrm{OH}
\end{array}\right. \\
\mathrm{C}_{6} \mathrm{H}_{2}\left\{\begin{array}{l}
\mathrm{OH} \\
\mathrm{OH} \\
\mathrm{CO} . \mathrm{OH}
\end{array}\right.
\end{array}
\end{aligned}
$$

Hc subsequently changed this formula to that of an ethereal anhydride, as follows:

$$
\begin{array}{r}
\mathrm{C}_{6} \mathrm{H}_{2}\left\{\begin{array}{l}
\mathrm{OH} \\
\mathrm{OH} \\
\mathrm{OH} \\
\mathrm{OO}
\end{array}\right. \\
\mathrm{C}_{6} \mathrm{H}_{2}\left\{\begin{array}{l}
\mathrm{O} \\
\mathrm{OH} \\
\mathrm{OH} \\
\mathrm{CO} . \mathrm{OH}
\end{array}\right.
\end{array}
$$

Schiff also investigated the reaction, first described by Löwe, of arsenic acid and gallic acid, which the lattcr considered to be an oxidation. Schiff, however, obtained similar results as with phosphorus oxychloride, and considered it an easier method for obtaining digallic acid, since heating the gallic acid with a dilute solution of arsenic acid was sufficient to effect the conversion. There is, however, considerable difficulty in removing the arsenic from the tannic acid, a portion of the latter being reconverted into gallic acid. 
By heating digallic acid as well as a purified natural tannic acid with acetic anhydride, Schiff obtained pentacctyl-tannin, $\mathrm{C}_{14} \mathrm{H}_{5}\left(\mathrm{C}_{2} \mathrm{H}_{3} \mathrm{O}\right)_{5} \mathrm{O}_{9}$, consisting of warty crystals melting at $137^{\circ}$. This compound is insoluble in water and cold alcohol, but moderately soluble in hot absolute alcohol, and gives no color reaction with salts of iron.

Two years later, in 1873, Schiff published a review of his former work, with the maturer conclusions which expcricnce gave him. He offered the following as the reaction taking place between gallic acid and phosphorus oxychloride :

$$
4 \mathrm{C}_{7} \mathrm{H}_{6} \mathrm{O}_{5}+\mathrm{POCl}_{3}=2 \mathrm{C}_{14} \mathrm{H}_{10} \mathrm{O}_{9}+\mathrm{PHO}_{3}+3 \mathrm{HCl} \text {. }
$$

The tannic acid thus obtained gave a blue-black precipitate with ferric salts, yielded pyrogallic acid on heating, and was converted into gallic acid by the action of dilute acids, without the formation of a trace of glucose. Phosphorus pentachloride and trichloride also converted gallic into tamnic acid, but some intermediate and decomposition products resulted.

Schiff also further investigated the action of arsenic acid on gallic acid, and determined that when they are heated togetler in aqueous solution the change into tannic acid is complete without the arsenic acid undergoing any change. He considered the reaction to be as follows :

(1) $\mathrm{C}_{7} \mathrm{H}_{5} \mathrm{O}_{4} \cdot \mathrm{OH}+\mathrm{HAsO}_{3}=\mathrm{C}_{7} \mathrm{H}_{5} \mathrm{O}_{4} \cdot \mathrm{O} \cdot \mathrm{AsO}_{2}+\mathrm{H}_{2} \mathrm{O}$;

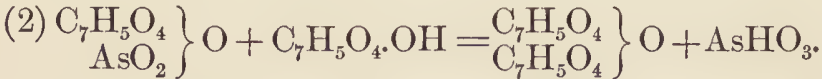

Pure digallic acid was recommended to be prepared 
by boiling an alcoholic solution of gallic acid and arsenic acid, the arsenic to be removed from the filtrate by hydrogen sulphide, the solution evaporated to dryness, dissolved in a small quantity of alcohol, ether added in excess, filtered, and the filtrate evaporated to dryness.

In a former paper Schiff supposed he had prepared a triacetyl and a tetraacetyl derivative of tannic acid, but later investigation convinced him that only the pentacetyl tannin existed, the other compounds being mixtures which resulted from the digallic acid containing some intermediate products with phosphorus.

Schiff at first concluded that " the compound present in the plants which yield tannic acid is probably a very unstable glucoside of polygallic acid, perhaps of the formula indicated by Strecker." "The least purified tannic acid is then the purest, since it contains the largest proportion of sugar."

Later he made the following statement: "That the glucose present in imperfectly purified natural tannin does not exist in the free state is proved by the fact that ether-alcohol and anhydrous alcohol dissolve such tannin freely. Unaltered tannin is probably a glucoside of digallic acid :"

$$
\mathrm{C}_{34} \mathrm{H}_{28} \mathrm{O}_{22}=\mathrm{C}_{6} \mathrm{H}_{12} \mathrm{O}_{6}+2 \mathrm{C}_{14} \mathrm{H}_{10} \mathrm{O}_{9}-2 \mathrm{H}_{2} \mathrm{O} .
$$

This formula corresponds with 23 per cent. glucose, and the amount of this substance obtained from natural tannin varies from nothing to 22 per cent, according to the extent to which the tannin has been subjected to purification.

C. Etti in 1884 coincided with Schiff's view of the constitution of tannic acid. 
We must conclude, from our present knowledge, that the tannin from galls as found in commerce is capable of being purified until it is simply digallic acid. It is, however, rarely, if ever, found in this condition, but contains variable amounts of glucose in weak combination; therefore tannic acid as we know it is either a glucoside of digallic acid or a mixture of this glucoside with variable proportions of digallic acid. 


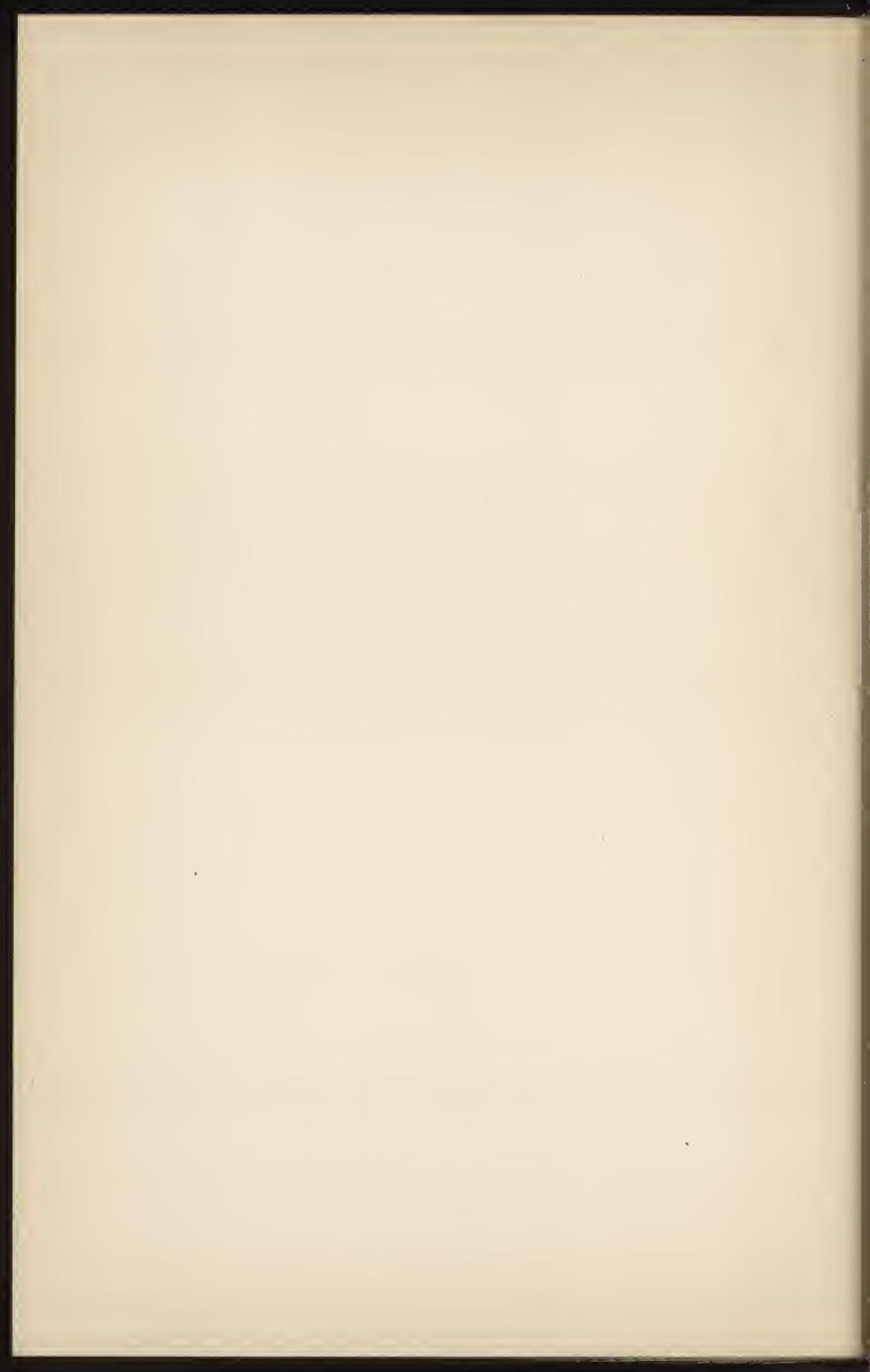


AN INDEX

TO THE

LITERATURE OF THE TANNINS. 


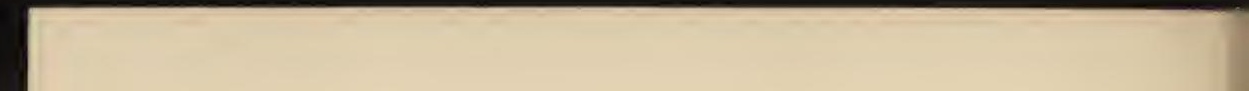




\section{INDEX OF AUTHORS.}

A.

Adrian, 159.

Aikin, A., 119.

Allen, A. H., 140.

Angillis-Mortier, 126.

Arata, P. N., 144, 149.

Archer, 135.

Arnaudon, J. S., 144.

Arnaudon, S. S., 159.

B.

B. E., 155 .

Baehr, R., 136.

Barbieri, 143.

Barfoed, C., 136.

Barreswil, 122.

Barrow, J., 138.

Bartholdi, 111.

Bassermann, F., 118.

Bastow, E., 156.

Baup, S., 117.

Becker, F., 153.

Bell, J., 121, 126.

Benoist, L., 157.

Bense, F. A. W., 154.

Beral, 120.

Berthellot, A. B., 112.

Berthellot, C. L., 112.

Bertrand, 126.

Berzelius, J. J., 116.

Bevan, E. J., 150.

Biggin, G., 110.

Bihot, L., 131.

Bissell, E. G., 144.
Bissell, W. B., 154.

Bley, L. F., 126, 128.

Bolley, P., 131, 133, 136.

Böttinger, C., 148, 150, 152, 153, $156,157,158,159,160,162$.

Bouillon-Lagrange, 111.

Bowman, H. K., 138.

Braconnot, H., 114, 118, 125.

Braemer, L., 159.

Brande, W. T., 114.

Braun, C. D., 137.

Breutel, E., 155.

Bridges, R., 122.

Brugnatelli, L. V., 113.

Buchner, A. W., 118, 126.

Buchner, L. A., 126.

Büchner, Ph., 123, 136.

Bujard, A., 162.

Burridge, J., 115.

Büsgen, 160.

c.

Cadet, 114.

Calvert, C., 129, 139.

Cap, 131.

Carles, P., 152.

Carpenè, 142 .

Casali, A., 152.

Casthelaz, 154.

Cavarra, A., 120.

Cavillius, 122.

Cech, C. O., 136.

Chaptal, B., 110.

Chevreul, 114. 
Christy, T., 144, 149.

Clark, 143.

Colin, 157.

Collier, P., 146, 147, 148.

Commaile, 133.

Cooper, J. T., 123.

Councler, C., 150, 151, 158.

Credner, H., 121.

Creuzburg, H., 119.

Cross, C. F., 150.

Cusson, 160.

D.

D., Dr., 153.

Darton, N. H., 149.

Davies, E., 148.

Daries, J. W., 132.

Davy, H., 112.

Delachanal, 156.

Descostiles, 110.

Desmond, W., 110.

Deyeux, C., 109.

Dierbach, 118.

Dieudonné, H., 155.

Dizé, J. J., 109.

Dominé, 123.

Dorffurt, 112.

Doubleday, E., 125.

Doutreleau, J., 153.

Dowling, J., 131.

Dreykorn, 138.

D'Urban, 132.

Durien, E., 154.

Duval, 121.

Dvorkovitch, P., 162.

E.

Eder, J. M., 145, 146, 147.

Eitner, W., 147, 150, 151, 155, 161, 162.
Erbstein, K. E. W., 110.

Erdmann, O. L., 117.

Estcourt, C., 141, 145.

Etti, C., 143, 148, 149, 151, 152, 158.

F.

Facilides, O., 137.

Fay, A., 110.

Fehling, 128.

Fernandez, 113.

Fleck, H., 131.

Fölsing, A., 161.

Freda, P., 145, 146, 147.

Frerichs, 125.

Fridolin, A., 151.

Fuchs, 110.

G.

Gantter, F., 159.

Gardiner, W., 152.

Gartenmeister, 160.

Gauhe, F., 133.

Gautier, A., 143, 144, 145.

Gawalovski, A., 150.

Geiseler, 130.

Geisler, J. F., 152.

Gerland, B. W., 133.

Giles, J., 117.

Gintl, W., 150.

Girardin, 121.

Giraud, 160.

Girgensohn, L., 141.

Godeffroy, 147.

Gondolo, P., 149.

Good, W., 115.

Grabowski, A., 134, 135, 137.

Graham, T., 132.

Grassi, E., 140, 142.

Grassmann, 114.

Gray, G., 110.

Green, F. V., 144. 
Griessmayer, V., 139.

Guenez, E., 160.

Guibourt, 122, 124, 125.

Guignet, C. E., 162.

Guillot, M., 111.

Günther, N., 138.

Guyard, A., 152.

\section{H.}

Haddock, A. G., 147.

Hagen, 121.

Hallwachs, 133.

Hamilton, W., 124.

Hammer, K., 131.

Handtke, R., 132.

Harff, H., 119.

Hartig, T., 137.

Hartwich, C., 147, 148, 151, 162.

Hatchett, C., 113.

Hatzfeld, A., 141.

Heinecke, 128.

Heinz, H. J., 134, 139.

Hennig, C., 128.

Henry, M., 116, 154.

Henry, O., 118.

Hermbstadt, S. F., 111.

Hesse, O., 157.

Heumann, C., 122.

Hill, A., 149.

Hinsdale, S. J., 160.

Hlasiwetz, H., 135, 136, 137.

Höhnel, F. R., 148.

Hooper, D., 159.

Hooxmun, P. J., 143.

Hornung, 123.

Horsley, J., 129.

Howison, J., 112.

Hunefeld, 121.

Hunt, B., 154.

Hurst, G. H., 155.
I.

Ishikawa, I., 148.

J.

Jackson, R., 152.

Jahn, H., 146.

Jahoda, R., 161.

Jean, F., 143, 144, 150, 154, 162.

Jennings, H. C., 130.

Johanson, E., 143, 145, 149, 151.

John, 114.

Johnson, A., 111.

Jorissen, A., 150.

Judd, W., 133.

K.

Kaemmerer, H., 143.

Kalinowsky, J., 123.

Kampffmeyer, 123, 124.

Kapff, S., 161.

Karsten, E. J. B., 111.

Kastner, K. W. G., 123.

Kathreiner, F., 145, 146, 147.

Kawalier, 129, 130.

Kay, P. 156.

Kendrick, W., 115.

Kestler, C., 117.

Kingzett, C. T., 146.

Klinger, A., 162.

Knop, A., 127.

Knop, W., 127 .

Koch, R., 157, 158.

Koechlin, J., 150.

Kohlrausch, O., 149.

Kohnstein, B., 153.

Kopp, E., 133.

Kraus, G., 159.

Kubly, 135.

Kursak, 132. 
Kurtz, C. M., 140.

Kutscher, F., 159.

L.

Lacaze-Duthiers, 128.

Lamasse, 152.

Lambert, A., 159.

Lang, C., 128.

Larocque, A., 121.

Laurent, A., 127.

Leconnet, 119.

Leeds, A. R., 148.

Lehman, A., 148, 150.

Lelievre, 110.

Leuchs, J. O., 132.

Lidow, A., 158.

Liebig, J., 117, 118, 120.

Lotichius, C. A., 140.

Löwe, J., 135, 137, 139, 140, 141, $142,148$.

Löwenthal, J., 131, 144.

Löwig, C., 120.

Luboldt, 130.

Luca, S. D., 149.

Luck, E., 126,

Luckombe, 125.

\section{M.}

Mabern, T., 153.

Macadam, 117.

Macagno, J., 140, 148, 156.

Macbride, D., 109.

Macewan, P., 153.

Maiden, J. H., 160.

Malin, G., 135.

Maltchewsky, 160.

Marquart, L. C., 118.

Marriage, J. H., 132.

Martius, T. W. C., 120.

Masson, 146.
Maumené, 142.

McMurtrie, W., 139, 143, 144.

Meerkatz, J., 155, 158.

Mercadante, 141.

Merrick, J. M., 140.

Meyer, G., 160.

Mierzinski, S., 156.

Minutoli, 116.

Mittenzwey, 133.

Moeller, J., 145, 147.

Mohr, 124.

Moll, J. W., 153, 155.

Monier, 130.

Moullade, A., 160.

Mulder, G. J., 125.

Müller, $\mathrm{F}$., 122.

Müller, G., 131.

Müller, J., 125.

Mulligan, J., 131.

Müntz, A., 138, 141, 142, 143, 149.

Musset, F., 151, 153.

N.

Nass, P., 152.

Nasse, O., 152.

Nees v. Esenbeck, 116, 117.

Neubauer, C.. 129, 139, 140.

Neubrand, J. G., 138.

Nötzli, 155.

\section{O.}

Orth, V., 129.

Oser, J., 143.

P.

Palm, R., 139.

Palmer, A. W., 145.

Palmer, T. C., 156.

Parrish, E., 131. 
Pässler, J., 161.

Patterson, W., 120.

Paul, B. H., 130, 146.

Pavesi, 141.

Payen, 119.

Peacock, J. C., 162.

Peligot, E., 122.

Pclletier, 110, 114.

Pelouze, J., 118.

Pereira, J., 123.

Perret, E., 145, 152.

Pettenkofer, 128.

Pfaff, C. H., 113, 114, 117.

Plisson, 116.

Poh], J. J., 129.

Preisser, F., 121.

Pribram, R., 134.

Procter, H. R., 141, 143, 144, $145,155,156,160,161,162$.

Procter, W., 133.

Proctor, B. S., 158.

Proust, 110, 111.

Prud'homme, 140.

R.

Raabe, 148.

Ramspacher, 141, 142.

Ranke, H., 127.

Rau, H. M., 156.

Rawson, S. G., 159.

Rebling, 129.

Regnauld, J., 141.

Reichardt, 138.

Reinitzer, F., 150, 158.

Reinsch, 120, 135.

Rembold, O., 134, 135, 137.

Remont, A., 149.

Richards, E. S., 145.

Riche, 149.

Riegel, 151.
Risler-Beunat, 133.

Robiquet, $119,120$.

Robiquet, E., 127, 128.

Rochleder, F., 124, 125, 127, $128,129,130,134,135,136$, 137.

Roder, 126.

Rodsey, 117.

Roos, L., 160.

Roquès, 151.

Rothe, O., 138.

Rotondi, 141.

Roxburgh, W., 112.

Rulf, 153.

Rutsch, 125.

S.

Succ, 138.

Salzer, Th., 137.

Sandrock, B., 127.

Saul, J. E., 155.

Schel, J., 142.

Schenk, 126.

Scherer, J. A., 112.

Scherk, C., 162.

Schiff, H., 130, 139, 140, 142, $146,147,156$.

Schlumberger, A., 132.

Schmidt, 141.

Schmieden, T., 137.

Schoen, 149.

Schönbcin, C. F., 131.

Schröder, J., 150, 157, 161.

Schubarth, 123.

Schulze, E., 158.

Schulze, F., 134.

Schwarz, R., 128.

Seemann, 126.

Seguin, A., 110.

Sertürner, F., 113. 
Sharples, S. P., 151.

Sheldon, W., 115.

Siedler, P., 161.

Siewart, 136, 145.

Simand, 150, 151, 153, 155, 156 , 157.

Simpkin, S. J., 142.

Skey, W., 134.

'Smedt, 133.

Sonne, W., 159.

Sonnenschein, 153.

sprengel, C , 117.

Staffel, 126.

Stein, W., 125.

Stenhousc, J., 121, 122, 123, 132, $141,142$.

Stocder, 143.

Strecker, A., 127, 128.

Svanberg, 119.

Swayne, 109.

T.

Terreil, A., 140.

Thompson, W., 142.

Tieghman, Ph., 134.

Tod, W., 129.

Tollens, 158.

Tonner, 132.

Toulmouche, 119.

Trimble, 156, 157, 158, 160, 162.

Trömer, 110.

Trommsdorff, J. B., 112, 118.

Turnbull, 124.

U.

Ulbricht, R., 154.

V.

Vauquelin, 111.

Vedova, F. G., 146.
Vignon, L., 160.

Villon, A., 156, 159.

Vincent, 156.

Vinen, 129.

Vircy, D'A., 115.

Virey, J. J., 115, 116.

Vogel, J. H., 161.

\section{W.}

Waage, Th., 161.

Wackenroder, H., 120, 121.

Wagner, E., 158.

Wagner, R., 126, 127, 134, 139.

Waltl, J., 116.

Warington, R., 124.

Watson, W., 146.

Watts, J., 135.

Wehmer, 158.

Weiss, B., 155.

Westermaicr, 153.

Wetherill, C., 124.

White, J. T., 159.

White, T., 114.

Whitely, R. L., 161.

Wiegand, 132.

Wildenstein, R., 133.

Willuszewitcz, 155.

Wittstein, G. C., 127.

Wöhler, 125.

Wohmann, W., 140.

Wolf, A., 138.

Wolff, E., 132.

Wood, J. T., 161.

Wosresensky, A., 120.

Wuttig, J. F. C., 113.

\section{$z$.}

Ziegler, E.; 154, 156.

Zölffel, G., 161.

Zwenger, C., 121. 


\section{N D E X}

TO THE

\section{LITERATURE OF THE TANNINS.}

\section{1.}

Abgekurztes Verfahren, die Gallapfelsäure zu gewinnen. Von Mich. Jean Jerome Dizé. Jour. Physik, 7, 399 (abstract 1793); from Observations sur la physique, sur l'histoire naturelle et sur les arts, par MM. l'Abbé Rozier, Mongez et De la Metherie, 39, 420, Paris, 1791.

\section{2.}

Communication relative to the use of Oak-Leaves in Tanning. By George Swayne. Trans. Soc. Arts, Io, 153.

\section{3.}

Mémoire sur la noix de galle, contenant son analysc, celle de l'acide galliquc, et un examen particulier du précipité opéré par ses deux substances lorsqu'on les mêle avec le sulfate de fer. Par le cit. Déyeux. Ann. Chim., I7, 1 ; abstract Jour. Physik, 42, 401.

\section{5.}

An Improved Method of Tanning Leather. By David Macbride, M.D. Repert. Arts and Manuf., 2, 341 and 382. 


\section{6.}

Some considerable Improvements in the Art of Tanning Leather. Patent to Anthony Fay, dated July 17, 1790. Repert. Arts and Manuf., 4, 217.

Rapport au Comité de Salut public, sur les nouveaux moyens de tanner les cuirs, proposés par le cit. Armand Seguin. Par les citoyens Lelièvre et Pelletier. Ann. Chim., 20, 15. Translation in Repert. Arts and Manuf., 8,272 and $3+1$.

\section{7.}

Method or Process of Tanning all Sorts of Hides and Skins, \&c. Patent to William Desmond, dated January 15, 1796. Repert. Arts and Manuf., 6, 7.

\section{8.}

Extrait d'un mémoire de M. Proust, sur le principe tannant. Par le cit. Descostiles. Ann. Chim., 25, 225. Translation in Repert. Arts and Manuf., II, 59 (1799).

\section{9.}

Experiments to determine the Quantity of Tanning Principle and Gallic Acid contained in the Bark of various Trees. By Gcorge Biggin, Esq. Phil. Trans., 89, 259. All. Jour. Chem., 5, 46 (1800).

Chemische Betrachtungen über die Wirkung der Beizen bcym Rothfärben des Kattuns. Vom Burger Chaptal. All. Jour. Chem., 2, 235.

Surrogat für Galläpfel. Von Herr Trömer. All. Jour. Chem., 3, 385 (abstract).

Surrogat für Galläpfel. Von Herr Prof. Fuchs. All. Jour. Chem., 3, 739 (abstract).

Surrogat für Galläpfel und Eichenrinde. Von Herr G. Gray. All Jour. Chem., I, 444 (abstract).

Surrogat für Galläpfel. Von K. E. W. Erbstein. All. Jour. Chem., 4, 423. 
1800.

Rapport d'un mémoire de M. Proust, sur différens points intéressans de la Chimie. Par le eit. Vauquelin. Ann. Chim., 35, 32. All. Jour. Ohem., 2, 252 (1799).

\section{1.}

On the production and applieation of Myrobalans and their use as a substitute for Aleppo Galls. By Dr. Alexander Johnson. Trans. Soe. Arts, 19, 343.

Gold Medal for the Preparation of Tan. Trans. Soe. Arts, $19,32$.

Resultate der bisher über den Gerbstoffangestellten Untersuehungen. Von E. J. B. Karsten. All. Jour. Chem., 7, 472.

Versuehe und Bemerkungen über die Gerbung des Ober- und Soblleders dureh verschiedene Vegetabilien, mit Rücksicht auf die quantitativen Verhältnisse des darin befindliehen gerbenden Stoffes, ihrer Vergleiehung gegen die Eichenrinde, und der Zeitraume, welche eine jede dieser Substanzen zum Gahrmaehen der Häute erfordert. Vom Dr. Sigismund Friedrich Hermbstadt. All. Jour. Chem., 6, 415 and 421.

\section{2.}

Gold Medal for the Preparation of Tan. Trans. Soe. Arts, 20, 36.

Chemische Untersuehung der Rinde der gemeinen weissen Weide. Vom Burger Bartholdi. All. Jour. Chem., 8, 294 ; Ann. Chim., 30, 268.

Expérienees sur le principe tannant, et réflexions sur l'art du tannage. Par le eitoyen Mérat Guillot. Ann. Chim., 4I, 323; Repert. Arts and Manuf., r6, 394.

Extrait d'un mémoire de M. Proust, sur le tannin et ses espèces. Ann. Chim., 4I, 92 ; abstraet by BouillonLagrange. 


\section{3.}

An Aecount of some Experiments and Observations on the constituent Parts of astringent Vegetables; and on their Operation in Tanning. By Humphry Davy, Esq. Phil. Trans., 93, 233.

Schreiben über die Identität der Gallussäure und des Gerbestoffs. Von Joh. Andr. Scherer. All. Jour. Chem., ro, 223.

Gold Medal for the Preparation of Tan. Trans. Soe Arts, 2I, 40.

\section{4.}

Neue Beiträge zu nähern Kenntniss der Natur des Gerbestoffs. Von J. Bartholma Trommsdorff. Neu. All. Jour. Chem., 3, 111; Repert. Arts. and Manuf. [2], 8,46 , and 129 .

Gold Medal for the Preparation of Tan. Trans. Soc. Arts, 22, 10.

Preparation of Tan made in the East Indies from the Bark of the Mangrove Tree. By Dr. James Howison. Trans. Soc. Arts, 22, 201.

\section{5.}

Gold Medal for the Preparation of Tan. 'L'rans. Soe. Arts, 23, 9.

East India Galls (Aldacay or Caducay Galls). By Dr. William Roxburgh. Trans. Soe. Arts, 23, 407.

Ueber die Natur der adstringirenden Substanzen. Neu. All. Jour. Chem., 6, 224 ; taken from second edition of Elémens de l'art de la teinture, par C. L. et A. B. Berthollet, tome I, p. 104.

Ueber Darstellung der Galläpfelsäure. Von Dorffurt. Neu. All. Jour. Chem., 6, 222 (abstraet). 
Galläpfelsäure von dem Samen des Schmacks. Von Herr. Fernandes. Neu. All. Jour. Chem., 6, 231 (abstract).

Beweis der Identität der Gallussäure und des Gerbestoffs. Von J. F. C. Wuttig. Neu. All. Jour. Chem., 6, 194.

On an artificial Substance which possesses the principal characteristic Propertics of Tannin. By Charles Hatchett, Esq., F.R.S. Phịl. Trans., 95, 211 and 285.

\section{6.}

Gold Medal for the Preparation of Tan. Trans. Soc. Arts, 24, 7.

A third Series of Experiments on an artificial Substance which possesses the principal charactcristic Properties of Tannin. By Charles Hatchett, Esq., F.R.S. Phil. Trans., 96, 109.

\section{8.}

Uebcr die nach Scheele's, Richter's und durch Sublimation bcreitcte Galläpfelsäure. Von Prof. C. H. Pfaff. Jour. Chem. Physik und Min., 5, 327.

Ueber einc Eigenthümlichkeit des Geschmacks der adstringirenden Substanzen. Von Prof. C. H. Pfaff. Jour. Chem. Physik und Min., 5, 331.

\section{2.}

Beitrag zul Kenntniss des Gerbstoffs und der Galläpfelsäurc. Von F. Sertürncr. Jour. Chem. Physik, 4,410 .

Courte notice sur le cachou et son analyse, et sur les différentes espèccs de gomme kino. Par L. V. Brugnatelli. Bull. de Pharm., 4, 366. 


\section{3.}

The Application of Larch-Bark, to answer all the Purposes of Oak-Bark, in Tanning Leather. By Thomas White. Trans. Soc. Arts, 31, 81.

1814.

Ueber den Chinastoff und die charakterischen Eigenschaften des Chinaharzes. Von Prof. C. H. Pfaff. Jour. Chem. Physik, ro, 265.

On Tannin and some new Combinations of the Gallic Acid with Vegetable Substances. By M. Pelleticr. Repert. Arts and Manuf. [2], 25, 304.

Examen du Rhus typhinum. Par M. John. Jour. de Pharm., 6, 77.

\section{5.}

Ueber die Verbindung des Gerbestoffs mit dem vegetabilischen Schleime. Vom Apothcker Grassmann. Jour. Chem. und Physik, r5, 42.

\section{7.}

Sur les végétaux astringens, et principalement sur ceux qui sont propres au tannage des cuirs. Par M. Cadet. Bull. de Pharm., 3, 100; Ann. Chim. et Phys., 4, 404 .

Observations on an Astringent Vegetable Substance from China. By William Thomas Brande. Phil. Trans., 107, 39 .

\section{8.}

Lettre de M. Cherreul a MM. les Redacteurs des Annales de Chimie et de Physique, sur l'acide cllagique de M. Braconnet. Ann. Chim. Phys., 9, 329. 


\section{9.}

Die Ratanhiawurzel und ihr Extract. Buch. Rep. Pharm., 7; 408 (a review).

The Application of Chestnut Wood to the Arts of Tanning and Dyeing. By William Sheldon. Am. Jour. Science, I, 312.

\section{0.}

Des galles végétaux, et des insectes qui les produisent. Par MM. D'A . . . . ct J.-J. Virey. Jour. de Pharm., 6, 161.

Invention of an Improvement in the Art of Tanning Hides and Skins and for Barking or Colouring Nets, Sails, and other articles by the Application of certain Matcrials hitherto unused for that purpose. Patent by William Good. Jour. Arts and Science, I, 97.

\section{1.}

Combination of Apparatis for Extracting a Tanning Matter from Bark and other Substances containing such Tanning Matter. Patent by William Kendrick. Jour. Arts and Science, 2, 171.

\section{3.}

De l'organisation des tissus végćtaux dans les excroissances appelées galles. Par J.-J. Virey. Jour. de Pharm., 9, 314.

New Material for Tanning from New South WalcsExtract of Mimosa Bark. Jour. Arts and Science, 5, 262 (report of Committee); Repert. Arts and Manuf. [2], 45, 337 (1824).

\section{5.}

On Tanning and the Use of the Barkometer. By John Burridge. Jour. Arts and Science, 9, 27. 
Hemlock for Tanning. Jour. Arts and Science, 9, 380 .

On the employment of the Wood and Bark of the Chestnut Tree in Dyeing and Tanning. Repertory of Patent Inventions, I, 108.

\section{6.}

Nouvelle substance astringente pour la teinture, dite Algarovilla. Par J.-J. Virey. Jour. de Pharm., r2, 296.

Extracts from Bark. Jour. Arts and Science, ro, 161.

\section{7.}

Du kino véritable de la Gambie ou de l'Afrique; de son origine, et des divers sucs concrets astringens, usites en médecine. Par M. J.-J. Virey. Jour. de Pharm., r $3,228$.

Ucber den Gerbstoff der Galläpfel, der Eichenrinde, der Chinarinde, des Catechins und des Kinos. Von J. J. Berzelius. Jahresbericht, 7, 244; Lehrbuch, 6, 209 (edition of 1837); Pogg. Ann., Io, 257.

Mémoire pour faire suite à l'histoire de la quinine, de la cinchonine, et de l'acide quinique. Par MM. Henry fils et Plisson. Jour. de Pharm., I3, 268 and 369.

\section{8.}

Ueber kino und extr. ratanhiac amer. Von Prof. Nees v. Esenbeck d. J. Buch. Repert. Pharm., 27, 211.

Bemerkungen über den Gerbestoff. Von Dr. J. Waltl. Buch. Repert. Pharm., 27, 258; Jour. tech. und ökonomische Chem., 2, 28.

Ueber den in Europa seit cinigen Jahren eingeführten Färbstoff genannt Bablah. Vom Generallieutenant v. Minutoli. Jour. tech. und ökonomische Chem., 2, 475 . 
Ueber Gerbstoff, Galläpfelsurrogate und Tintenbereitung. Vom Herausgeber Otto Linné Erdmann. Jour. tech. und ökonomisehe Chem., 2, 21.

Ueber Gallussäure, Gerbstoff und das Eiweiss grünfarbende Prineipe der Kaffeebohnen. Vom Prof. C. H. Pfaff. Jour. Chemie und Physik, 4, 410.

\section{9.}

Mode of Extracting Tannin from Bark. Patent by Joseph Giles (April 11, 1827). Jour. Arts and Scienee [2], 2, 219.

\section{1.}

Untersuehung der Tormentillwurzel auf ihren Gehalt an Gerbstoff. Vom Dr. C. Sprengel. Jour. tech. und ökonomisehe Chem., ro, 40.

\section{2.}

Sur l'aeide kinique et sur quelques-unes de ses combinaisons. Par M. S. Baup. Ann. Chim. Phys., 51, 56.

Some preliminary Experiments upon the pod of Cesalpinia Coriaria, or Dividivi. By Mr. Rodsey. Communieated by Captain Maeadam, of the Royal Marines. Edinburgh New Phil. Jour., 1832, 135.

Chemisehe Untersuchung der enltivirten Holzarten auf ihre fenerfesten Bestandtheile. Von Dr. C. Sprengel. Jour. teeh. und ökonomische Chem., r3, 382.

Bemerkung über Catechu. Von Fr. Nees v. Esenbeek. Annalen, r, 243.

Ueber die Zusammensetzung der Chinasäure. Von Justus Liebig. Annalen, 6, 14.

Versuehe über die Reaction der Gallus- und Gerbsäure, nebst kurzer Bemerkung über die Natur derselben. Von Carl Kestler. Buch. Repert. Pharm., 42, 381. 
Sur la jusée et l'éeoree de ehêne.-Existenee de la peetine dans l'éeoree des arbres. Par M. Henri Braeonnot. Ann. Chim. Phys., 50, 376 ; Jour. tech. und ökonomische Chem., ז3, 382.

\section{3.}

Neueste Entdeckungen über die Gerbsäure, oder den sogenannten Gerbstoff. Von Aug. Wilh. Buehner. Bueh. Repert. Pharm., 46, 316 (a review of the above prize essay).

Algaroba. Trans. Soe. Arts, 49, 97. (Papers on Colonies and Trade.)

\section{4.}

Mémoire sur le tannin et les aeides gallique, pyrogallique, ellagique et metagallique. Par J. Pelouze. Ann. Chim. Phys., 54, 337 ; Jour. Chim. Méd., ro, 257 ; Pogg. Ann., 29, 180; Annalen, ro, 145; Jour. prak. Chem., 2, 301.

Ueber die Zusammensetzung der Gerbsäure (Gerbestoff) und der Gallussäure. Von Justus Liebig. Annalen, ro, 172 ; Jour. prak. Chem., 2, 321.

Ueber die Zusammensetzung der Gerbsäure. Von J. Pelouze. Annalen, ro, 210 (aus einem Briefe an J. L.).

Ueber die salzigen Bestandtheile der Beeren des Gerbersumachs. Von Dr. J. B. Trommsdorff. Annalen, ro, 328 .

Ueber den Thee. Von L. C. Marquart. Annalen, Io, 328.

Ueber Cortex Radicis Ratanhiae. Von Friedr. Bassermann. Annalen, II, 226.

Bemerkung über die offieinellen Früehte der Eichen. Von Prof. Dierbaeh. Annalen, 12, 85.

De l'application du tannin pur eomme moyen d'alcaloïmétrie. Par M. O. Henry. Jour. de Pharm., 20, 429. 


\section{5.}

Sur la méthode de déplacement appliquée au traitement de la noix de galle, etc. Par M. Robiquet. Jour. de Pharm., 21, 113.

De l'action du tannin sur les bases salifiables organiques, et applications qui en dérivent. Par M. Ossian Henry. Jour. de Pharm., 21, 213; Annalen, I5, 300 .

Ueber dic Wirkung des Gerbstoffs und einigen andern Substanzen auf die Wurzeln der Pflanzen. Von M. Payen. Archiv der Pharm. [2] 2, 305.

Mémoire eoncernant l'action des plantes contenant du tannin, et l'action du tannin lui-même, sur la propriété vomitive du tartrate antimonial de potasse, et sur diverses conséquences thérapeutiques nouvelles. Par M. A. Toulmouche. Jour. de Chim. Méd., ro, 198; Buch. Repert. Pharm., 65, 97.

\section{6.}

Note sur le tannin. Par M. Leconnet. Jour. de Pharm., 22, 149; Annalen, I8, 179.

On Tanning and Leather Dressing. By A. Aikin. Trans. Soc. Arts, 5o, 192.

Untersuch ungen des Katechus und einiger sich daraus bildende Stoffe. Von Svauberg. Pogg. Ann., 39, 161; Jour. prak. Chem., ro, 494.

Notice sur l'acide gallique. Par M. Robiquet. Jour. de Pharm., 22, 483; Jour. prak. Chem., II, 481.

Gerbsaures Quccksilberoxydul, Hydrargyrum tannicum oxydulatum, Tannas hydrargyrosus. Von Ieinrich Harff. Archiv der Pharm. [2], 5, 294.

Beiträge zur Kenntniss der weinigen Gährung ainylonhaltiger Substanzen. Von H. Ch. Creuzburg. Jour. prak. Chem., 9, 299. 


\section{7.}

Improvement in converting hides and skins into leather by the application of matter obtained from a material not hitherto used for that purpose. Patented by William Patterson. Jour. Arts and Science [3], ro, 93 .

Ueber Gallae pistacinae. Von Dr. Th. W. C. Martius. Annalen, 21, 179.

Tanningensäure (Catechusäure). Annalen, 24, 215.

Du tannin considéré sous les rapports de sa préparation, de son action sur les tissus devenus inertes et sur les tissus vivants ou malades. Par A. Cavarra. Jour. de Pharm., 23, 88.

\section{8.}

Ueber die Zusammensetzung der Chinasäure. Von Alexander Woskresensky. Annalen, 27, 257.

Ueber die Zusammensetzung der Gerbsäure. Von Justus Liebig. Annalen, 26, 128.

Faits pour' servir à l'histoire de l'acide gallique. Par M. Robiquet. Ann. Chim. Phys. [2], 64, 385; Annalen, 25, 131.

\section{9.}

Uebersicht über die Eichengerbsäure, Gallussäure, Ellagsäure, Brenz- und Melangallussäure. Von Dr. C. Löwig. Archiv der Pharm. [2], I7, 57.

Préparation artificielle du cachou brun. Par M. H. Reinsch. Jour. de Pharm., 25, 733 ; Jour. prak. Chem., 16, 509 .

Beiträge zur Kenntniss der Cateehusäurc. Von H. Wackenroder. Annalen, 3I, 72.

Note sur le tannin. Par M. Beral. Jour. de Chim. [2], 5, 225; Archiv der Pharm. [2], I9, 309 ; Am. Jour. Phar., 1841, 232. 
1840.

Note sur la préparation du tannin. Par M. Duval. Ann. Chim. Phys., 74, 222 ; Annalen, 36, 95 ; Am. Jour. Phar., 1842, 171.

Sur le cachou épuré du commerce. Par MM. J. Girardin et F. Preisser. Jour. de Pharm., 26, 50.

On the Preparation of Tannin. By Jacob Bell. Phar. Jour. Trans., r, 410.

1841.

Nouvelles recherches pour servir à l'histoire de l'acide gallique. Par Antoine Larocque. Jour. de Pharm., 27, 197.

Ueber die Idiotypie unkrystalliniseher organischer Körper, insbesondere der Eichengerbsäure und Huminsäure. Von H. Wackenroder. Jour. prak. Chem., 24, 18.

Ueber die Metamorphose der Eichengerbsäure in ibrer wässrigen Lösung. Von H. Wackenroder. Jour. prak. Chem., 24, 28.

Eigenschaften der Catechusäure naeh Untersuchungen von $\mathrm{H}$. Wackenroder. Annalen, 37, 306.

Ueber Cateehin. Von Constantin Zwenger. Annalen, 37,320 .

Ueber die Zusammensetzung des Catechins. Von Robert Hagen. Annalen, 37, 336.

Versuche zur künstlichen Bildung der Gallussäure oder Umwandlung der Gerbsäure in jene. Vom Prof. Hunefeld. Jour. prak. Chem., I6, 359.

Gallus-Handelnotizen. Von Hermann Credner. Archiv der Pharm., [2], 25, 93.

\section{2.}

On Pyrogallic Aeid, and some Astringent Substances which yield it. By Dr. John Stenhouse. Mem. Chem. Soc., r, 127 ; Annalen, 45, 1. 
On some Astringent Substances as sources of Pyrogallic Acid. By Dr. John Stenhouse. Mem. Chem. Soc., I, 132.

1843.

Examination of Astringent Substances (continued). By John Stenhouse, Esq., Ph.D. Mcm. Chem. Soc., I, 208.

Sur la constitution chimique des gallates et tannates dc fer et des teintures à base de fer. Par M. Ch. Barreswil. Compt.-Rend., r7, 739; Jour. prak. Chem., 30, 379 .

Observations on the Action of Ether on Galls. By Robert Bridges. Am. Jour. Phar., 1843, 40.

Vorläufigc Notiz über einen rothen Farbestoff als Metamorphose der Gerbsäure aus der Apfelbaumrinde. Von Ch. Heumann. Buch. Rep. Pharm., 81, 324.

Eisengrünender und eisenbläuender Gerbstoff. Von Herr Cavillius. Jahresbericht, 21, 275; Archiv der Pharm. [2], 36, 61.

Recherches sur la composition chimique du thé. Par M. Eug. Peligot. Compt.-Rcnd., 17, 107; Annalen, 47, 358 .

Untersuchung der Galläpfel. Von Guibourt. Anna. len, 48, 359; Revue Scient., I3, 32.

\section{4.}

Ueber Gerbestoff; eine Beantwortung der Preisaufgabe der Hagen-Bucholz'schen Stiftung auf das Jahr 1843. Von Friedr. Müller. Arehiv der Pharm. [2], $3^{8}, 121$ and 266.

On the Galls of Terebinthus and Pistacia. By M. Guibourt. Phar. Jour. Trans., 3, 377 and 381. 
On the Chinese Gall, called "Woo-Pei-Tsze," and on the Gall of Bolkhara, termed "Gool-I-Pista." By Jonathan Pereira. Phar. Jour. Trans., 3, 384.

Mémoire sur la préparation du tannin. Par M. Dominé. Jour. de Phar. Chim. [3], 5, 231.

Observations on Catechuic Acid. By John Thomas Cooper, Esq. Phil. Mag. [3], 24, 500; Dingler, 93, 380 ; Jour. prak. Chem., 33, 429.

Verglcichende Versuche über das Gerben von Kalbfellen mit Eichenlohe, Dividivi, Cateehu und Ellernrinde. Von Kampffmeyer. Dingler, 94, 154.

Gerbsäure. Von Hornung. Archiv der Pharm. [2], 39,32 .

1845.

Ueber Dividivi. Von Prof. Dr. Schubarth. Dingler, 97,316 .

Bericht über die Resultate angestellter vergleichender Gerbeversuche mit Eichen- und Ellcrnrinde, Catechu und Dividivi. Von W. Kampffmeyer. Dingler, 98 , 435. (Aus den Verhandlungen des Vereins zur Beförderung des Gewerbfleisses in Preussen 1845, 4te Lieferung.)

Galläpfel als Gährungs-Erreger. Von K. W. G. Kastner. Archiv der Pharm. [2], 44, 135.

Galläpfel-A etberöl. Von K. W. G. Kastner. Archiv der Pharm. [2], 44, 137.

Ucber Gallussäure und Gerbsäure, Verhalten dieser Säuren zu Basen, Darstellung, Eigenschaften und Constitution ihrer wichtigen Salze. Von Dr. Phil. Büchner, jun. Annalen, 53, 175 und 349 .

Reagens auf Chinasäure. Von Dr. J. Stenhouse. Annalen, 54, 100.

Verhalten von Gerbstoff zu Stärke. Von J. v. Kalinowsky. Jour. prak. Chem., 35, 201; Annalen, 56, 305 ; Chem. Gaz., 4, 65. 
A New Mode or Method of more expeditiously and effectually Tanning Hides and Skins, and of Extracting and Separating the Catechuic from the Tannic Acid in the Catechu or Terra-Japonica used in Tanning. Patent by Alexander Turnbull. Jour. Arts and Sciences [3], 26, 234 .

1846.

On the medical and economic Properties of the Rhizophora Mangle, or Mangrove Tree. By W. Hamilton. Phar. Jour. Trans., 6, 11.

Galläpfel von Terebinthus und chinesische Galläpfel. Von Guibourt. Arehiv der Pharm. [2], 5I, 190; Revue Scient., March, 1846.

\section{7.}

Note on the Means of Testing the Comparative Value of Astringent Substances for the Purpose of Tanning. By Robert Warington, Esq. Mem. and Proc. Chem. Soc., 3, 319 ; Chem. Gaz., 5, 147; Dingler, ı04, 316.

Vergleichende Gerbversuche zwischen Eichenrinde, Ellern rinde, Catechu und Dividivi. Von W. Kampffmeyer. Dingler, ro6, 323.

Ueber die Umwandlung der Gerbsäure in Gallussäure. Von Carl Wetherill. Jour. prak. Chem., 42, 247 ; Jour. Phar. Chim. [3], 12, 107; Am. Jour. Phar., 1848, 112.

Ueber die Natur der Tanninlösung, die bei der Extraction mit Aether erhalten wird. Von Dr. Mohr. Annalen, 6r, 352.

Untersuchung der Kaffeebohnen. Von Dr. F. Rochleder. Annalen, 63, 193. 
Ueber die Boheasäure und Gerbsäure der Blätter von Thea bohea. Von Dr. F. Rochleder. Annalen, 63, 202.

Mémoire sur les sucs astringents connus sous les noms de Cachou, Gambir et Kino. Par M. Guibourt. Jour. Pharm. Chim. [3], Ir, 24, 260, and 360, and 12, 37.

Ueber Gerbsäure. Von Professor G. J. Mulder. Buch. Rep. Pharm., Ior, 311 (1848), and 102, 38 (1849). (A us dem Holländischen von Dr. Johannes Müller.) Scheikundig. Onderzoek, IV. Dece, 639 ; Jour. prak. Chem., 48, 90 (1849); Chem, Gaz., 8, 41 (1850).

Note on the Insect forming the Chinese Galls. By Edward Doubleday. Phar. Jour. Trans., 7, 310.

\section{8.}

Uebel die Veränderung, wclche namentlich organische Stoffe bei ihren Uebergange in den Harn erleiden. Von Wöhler und Frerichs. Jour. prak. Chem., 44, 60. (From "Nachrich ten v. d. Göttingen A. Universität und der Königl. Ges. der Wissenschaften," 1848, No. 5.)

\section{9 .}

Analyse des glands, suivie de considérations sur la présence du sucre de lait dans les grains des végétaux. Par M. H. Braconnot. Ann. Chim. Phys. [3], 27, 392; Jour. prak. Chem., 49, 232.

Mecca or Bussorah Galls. By Mr. Luckombe. Phar. Jour. Trans., 8, 422 ; Am. Jour. Phar., 1849, 265.

Cortex Quercus. Von Dr. Rutsch. Buch. Rep. - Pharm., ro4, 401 (1850). (From "Centr.-Bl. des landwirthsch. Vereins in Bayern," 1849, Nro. 10, 374.)

Ueber chinesischen Gallus. Von W. Stein. Dingler, 114, 433, aus Polytech. Centralblatt, 1849, Liefer. 22. 
1850.

Nachträgliche Notiz über die chinesischen Galläpfel. Von Prof. Dr. Schenk. Buch. Rep. Pharm., ro5, 346.

Observations pratiques sur la préparation du tannate neutre de plomb. Par L. J. Angillis-Mortier. Jour. Pharm. d'Anvers, 6, 417.

Chinese Galls. By Jacob Bell. Phar. Jour. Trans., Io, 127.

Ueber sogenannten chinesischen Gallus und seine Bestandtheile. Von L. F. Bley. Archiv der Pharm. [2], 6r, 297.

Ueber Bassorah-Galläpfel. Briefliche Notiz von Dr. Bertrand an Dr. Bley. Archiv der Pharm. [2], 64, 52. Briefliche Notiz über chinesische Gallae. Von Dr. L. F. Bley. Buch. Rep. Pharm., I04, 80.

Ueber die chinesischen Galläpfel. Von Prof. Dr. Schenk. Buch. Rep. Pharm., ro5, 26.

Untersuchung der Rosskastanie. Von E. Staffel. Archiv der Pbarm. [2], 64, 26.

Bemerkung über Knoppern-Extract. Von Dr. A. Buchner, sen. Buch. Rep. Pharm., I05, 120.

\section{1.}

Moritannic Acid. By Dr. R. Wagner. Chem. Gaz., 9, 21 ; Jour. prak. Chem., 6r, 82.

Tannaspidic and Pteritannic Acid. By Dr. E. Luck. Chem. Gaz., 9, 452; Chem. Central., 1851, 657 and 676.

On Gambir. By Berthold Seemann. Phar. Jour. Trans., Ix, 576.

Ueber den Werth der chinesischen Galläpfel. Von L. A. Buchner, jun. Buch. Rep. Pharm., Io7, 313.

Istrianische Galläpfel. Von Roder. Chem. Central., 1851, No. 24. 
1852.

Zur Lehre vom thierischen Stoffumsatz. Von H. Ranke. Jour. prak. Chem., 56, 1.

The Tannic Acids of the Rubiaceæ. By F. Rochleder. Chem. Gaz., ro, 286; from Sitzber. der K. Akad. zu Wien, Jan., 1852.

Aspertannic Acid. Chem. Gaz., Io, 61; from Sitzber. der K. Akad. zu Wien, 1852.

Ueber die Constitution der Gerbsäure. Von A. Strecker. (Briefliche Mittheilung.) Annalen, 81, 248; Jour. prak. Chem., 56, 184.

Ueber die Gerbsäuren und eine Classe neuer stickstoffhaltiger Abkömmlinge der Gerbsäurereihe. Von Ad. Knop und Dr. W. Knop. Jour. prak. Chem., 56, 327 ; Chem. Gaz., ro, 333.

Ueber die Formel der Moringerbsäure. Von Prof. Dr. Rud. Wagner. Jour. prak. Chem., 57, 441; Chem. Gaz., 9, 21.

Sur les tannins et les glucosamides. Par M. Aug. Laurent. Compt.-Rend., 35, 161; Jour. prak. Chem., $57,169$.

Ueber dic Bereitung der Gerbsäurc. Von B. Sandrock. Archiv der Pharm. [2], 72, 265.

Recherches sur la fermentation gallique. Par M. E. Robiquet. Compt.-Rend., 35, 19.

\section{3.}

On the Preparation of Gallic Acid from Chinese Gallnuts. By Dr. G. C. Wittstein. Phar. Jour. Trans., I2, 444. (Aus Vierteljahresschrift für praktische Pharmacie, 1853, Hcft 1.)

Zur Geschichte der Entdeck. u. Zusammens. der Gerbsäure. Von A. Strecker. Jour. prak. Chem., 59, 191 ; Jour. Chem. Soc., 5, 102. 
Ueber Bestimmung des Gehaltes an Gerbstoff in Gerbmaterialien. Von Prof. Dr. Fehling. Würtembergisches Gewerbeblatt, 1853, No. 38; Dingler, rзo, 53 ; Archiv der Pharm. [2], 78, 45 ; Chem. Gaz., I2, 111; Jour. Phar. Chim., 26, 52.

Chemische und pharmakologische Prüfung des Gummi Kino. Von Dr. C. Hennig. Archiv der Pharm. [2], 73,129 .

Chemische Untersuchung der sogenannten Bassorah Galläpfel. Von Dr. L. F. Bley. Archiv der Pharm. [2], 75, 138.

Gallotannic Acid, Kinovatannic Acid. By F. Rochleder and R. Schwarz. Chem. Gaz., I I, 308.

Recherches pour scrvir à l'histoire des galles (structure). Par M. de Lacaze-Duthiers. Compt.-Rend., 36, 620.

\section{4.}

Vorkommen der Gerbsäure in den Holzpflanzen. Von Prof. Pettenkofer. Jahrb. der Pharm., I, 360; Jour. prak. Chem., 62, 508 ; Dingler, r34, 158.

Untersuchung der Galläpfelgerbsäure. Von Adolph Strecker. Annalen, 90, 328; Jour. prak. Chem., 62, 434 ; Compt.-Rend., 39, 49 ; Am. Jour. Phar., 1855, 49.

Note sur la constitution molćculaire du tannin et de l'acide gallique. Par M. E. Robiquet. Jour. Phar. Chim. [3], 26, 29; Am. Jour. Phar., 1855, 51.

Fabrication des Knoppern-Extracts. Von Carl Lang. Kunst- und Gewerbeblatt für Bayern, 1854, 268; Dingler, I35, 156 (1855).

1855 .

Ueber Darstellung des Tannins aus chincsischen Galläpfeln. Von Th. Heinecke. Archiv der Pharm. $[2], 83,4$. 
Ueber den präparirten Catechu. Von Dr. J. J. Pohl. Sitzber. der K. Akad. zu Wien, Band 12 ; Jour. prak. Chem., 64, 48.

Ueber Thuja occidentalis. Von A. Kawalier. Sitzber. der K. Akad. zu Wien, Band 13; Jour. prak. Chem., $64,16$.

Ueber die chinesischen Gelbschoten. Von M. V. Orth. Sitzber. der K. Akad. zu Wien, Band 13; Jour. prak. Chem., 64, 10.

On the Conversion of Tannic Acid into Gallie Acid in the Extracts of Tanning Substances. By Prof. Crace Calvert. Edinburgh New Phil. Jour., 1855, 265; Chem. Gaz., 12, 440; Dingler, 136, 221; Am. Jour. Phar., 1856,455 .

Aphis chinensis. Von Rebling. Archiv der Pharm. [2], 8r, 280.

Ueber den Gerbsäuregehalt mchrerer Galläpfelsorten. Von W. Tod. Archiv der Pharm. [2], 84, 9.

1856.

English Oak Galls. By Dr. Vinen. Phar. Jour. Trans., x6, 137; from Jour. Linn. Soe., 1856.

Spaltung der Gerbsäurc. Von Rochleder und Kawalier. Archiv der Pharm. [2], 87, 57; Chem. Central., 1857, 234.

Ueber Catechu und dessen Säuren. Von C. Neubauer. Annalen, 96, 337 ; Jour. prak. Chem., 67, 257.

On the Conversion of Tannic into Gallic Acid. By John Horsley. Reports in Brit. Assoe. for Adv. of Science, 1856, 52.

Notiz über die Gerbsäuren. Von Prof. Rochleder. Sitzber. der K. Akad.zu Wien, r8, 3 ; Jour. prak. Chem., 68,405 . 


\section{7.}

Ueber die Entfärbung des gerbstoffsauren Eiscn-oxyduloxyds durch Oxalsäure. Von Dr. Geiseler. Archiv der Pharm. [2], 89, 165.

Cadmiumtannat. Von Dr. Hugo Schiff. Annalen, 104, 327 .

Ueber die Galläpfelgerbsäure. Von Dr. F. Rochleder. Sitzber. der K. Akad. zu Wien, 22, 558; Chem. Gaz., 15, 228; Am. Jour. Phar., 1856, 464.

Occurrence of Tannic Acid in Plants. By B. H. Paul. Phar. Jour. Trans., 17, 174; Am. Jour. Phar., 1857,554 .

\section{8.}

Improvements in the Production and Application of Tannin or Tannic Acid. Patent by Henry C. Jennings. Jour. Arts and Sciences [3], 8, 158.

Mémoire sur la détermination du tannin des végétaux par les méthodes volumétriques. Par M. E. Monier. Compt.-Rend., 46, 577.

On the Tannin of Galls. By M. Kawalier. Chem. Gaz., 16, 421; from Sitzber. der Akad. der Wiss. zu Wien.

Gelber Farbstoff der grünen Theile von Thuja occidentalis. Von Dr. Friedrich Rochleder. Jour. prak. Chem., 74, 8.

Galläpfel-Gerbstoff. Von Dr. Friedrich Rochleder. Jour. prak. Chem., 74, 28.

\section{9.}

Ueber das Verhalten der Gerbsäure gegen Aether und Wasser. Von R. Luboldt. Jour. prak. Chem., 77, 357; Am. Jour. Phar., 1860, 322. 
Quantitative Bestimmung des Gerbstoffgehalts in gerbstoffbaltigen Körpern, nach der prämiirten Preisschrift des Apothekers Gustav Müller. Dingler, I5I, 69 ; Chem. Gaz., I7, 115; A m. Jour. Phar., 1859, 427.

On the Estimation of Tannin in some Tanning Materials. By John Mulligan and John Dowling. Chem. Gaz., I7, 430.

\section{0.}

Bestimmung. der Gerbsäure in den Gerbmaterialien. Von H. Flock. Gerberzeitung, 1860, Nr. 2, 3 und 4.

Versuch einer allgemeinen Massanalyse für sammtliche Farbstoffe, Gerbstoffe, etc. Von J. Löwenthal. Jour. prak. Chem., 81, 150.

Ueber das Verhalten des Sauerstoffes zur Gallusgerbsäure und Gallussäure. Von C. F. Schönbein. Jour. prak. Chem., 8r, 11.

Das Verhalten der Galläpfelgerbsäure gegen Aether, -ein Mittel zum Nachweis eines Wassergehalts des letzteren. Von P. Bolley. Schweiz. Zeit., 5, 54; Dingler, I57, 380 ; Annalen, II5, 63 ; Am. Jour. Phar., $1861,337$.

Tannate de bismuth. Par M. Cap. Jour. de Pharm. d'Anvers, r6, 170.

Du tannate de bismuth. Par M. L. Bihot. Jour. de Pharm. d'Anvers, r6, 363.

Neue Methode zur Bestimmung der Gerbsäure. Von Karl Hammer. Jour. prak. Chem., 81, 159; Dingler, 159, 300; Phar. Jour. Trans. [2], 3, 433.

\section{1.}

Note on the Supposed Chemical Compound of Tannic Acid, Ether, and Water. By Edward Parrish. Am. Jour. Phar., 1861, 207. 
Die Menge des Gerbstoffs in der Eichenrinde. Von E. Wolff. Krit. Bl. für Forst und Jagdw., 44, 167.

Titrirmethode zur quantitativen Bestimmung der Gerbsauren. Von Dr. Robert Handtke. Jour. prak. Chem., 82, 345.

Einfluss der Gerbsäure auf die Weingährung. Von Johann Carl Leuchs. Jour. prak. Chem., 82, 455.

Die Blätter von Epacris. Von Herrn Tonner. Jour. prak. Chem., 84, 441.

Tannin antidote de la strychnine. Par Mr. Kursak. Repert. Chim. App., 3, 99 ; Phar. Jour. Trans. [2], 2, 227.

On Some Varieties of Tannin. By John Stenhouse. Proc. Royal Soc., II, 401; Phar. Jour. Trans. [2], 3, 329 ; Dingler, 165, 150; Am. Jour. Phar., 1862, 252.

\section{2.}

Sätze über die physiologische Bødeutung des Gerbestoffs und der Pflanzenfärber. Von Wiegand. Bot. Zeitung, 1862, 121.

On Liquid Diffusion applied to Analysis. By Thomas Graham. Phil. Trans., 1861, 183 ; Jour. Chem. Soc., I5, 216 ; Annalen, I2I, 55.

A Process for Estimating Tannic Acid in Galls. By J. H. Marriage. Phar. Jour. Trans. [2], 3, 509.

Sur un extrait astringent de lentisque et de mysthe. Par Albert Schlumberger. Bull. Soc. Muhl., 32, 316 ; Chem. Central. [2], 8, 319.

\section{3.}

The Tannin Process. By J. W. Davies. Pub. by H. Greenwood, Liverpool.

English Ink-Galls. By Mr. D'Urban. Phar. Jour. Trans. [2], 4, 520. 
On the Estimation of Tannic Acid. By Dr. B. W. Gerland. Chem. News, 8, 54; Am. Jour. Phar., 1863, 519.

Zur Werthbestimmung gerbsäurehaltiger Materialien. Von Robert Wildenstein. Zeit. anal. Chem., 2, 137; Dingler, $\mathbf{1}$ 72, 231.

Ueber die Darstellung des Chinintannats. Von de Smedt. Jour. de Pharm. d'Anvers, I9, 198; Jour. Pharm. Chim. [3], 44, 133.

Zur Kenntniss des gerbsäuren Rosanilins. Von E. Kopp. Jour. prak. Chem., 92, 241; Chem. News, 7, 16. Zur Bestimmung der Gerbsäure. Von Dr. H. RislerBeunat. Zeit. anal. Chem., 2, 287.

\section{4.}

Mémoire sur une nouvelle méthode de dosage des matières astringentes végétales. Par M. Commaile. Compt.-Rend., 59, 399.

Beitrag zur volumetrischen Bestimmung der Gerbsäure, Gallussäure, sowie des Eisens, Mangans u. s. w. Von Moritz Mittenzwey. Jour. prak. Chem., 9I, 81.

Die Soja-, Zoga- oder Coua-Rinde als Färbematerial. Von Prof. Bolley. Jour. prak. Chem., 93, 361.

On the Odor of Commercial Tannic Acid. By William Procter, Jr. Proc. Am. Phar. Assoc., I2, 255 ; Am. Jour. Phar., 1865, 53.

Ueber die Bestimmung der Gerbsäure. Von Fr. Gauhe. Zeit. anal. Chem., 3, 122.

\section{5.}

Tannin in British Galls. By William Judd. Phar. Jour. 'Trans. [2], 7, 228.

Zur Bestimmung der Gerbsäure in gerbsäurehaltenden Materialien. Von W. Hallwachs. Zeit. anal. Chem., 5, 231; from Gewerbeblatt für das Grossherzogthum Hessen, 1865, Nr. 51 und 52. 


\section{6.}

Notiz über die Blätter von Epacris. Von Friedrich Rochleder. Jour. prak. Chem., 98, 208. Aus dem 53 Bde. der Sitzber. der K. Akad. der Wiss. zu Wien.

Notiz über die Bestandtheile der Wurzelrinde des Apfelbaumes. Von Dr. Friedrich Rochleder. Jour. prak. Chem., 98, 205. Aus dem 53 Bde. der Sitzber. der K. Akad. der Wiss. zu Wien.

Nenes Verfahren zur quantitativen Bestimmung des Gerbstoffs. Von R. Pribram. Zeit. für Chem. [2], 2, 634 ; from Wittstein's Vierteljahresschrift, 15, 520.

Beiträge zur Kenntniss und zur quantitativen Bestimmung der Gerbsäuren. Von Prof. Dr. Rudolf Wagner. Zeit. anal. Chem., 5, 1; Jour. prak. Chem., 99, 294.

Neues Verfahren zur Ermittelung des Gerbstoffgehaltes der Loh-Rinde. Von Prof. Franz Schulze. Dingler, ז82, 155 .

\section{7.}

Sur la fermentation gallique. Par M. Ph. Van Tieghem. Compt.-Rend., 65, 1091.

Ueber den Gerbstoff von Aesculus Hippocastanum. Von Fr. Rochleder. Archiv der Pharm., 178, 148. Aus dem Sitzber. der K. Akad. der Wiss. zu Wien. Jour. prak. Chem., I02, 103.

Tanninreinigung. Von H. J. Heinz. Phar. Zeit. Russ., 1867, 469.

Formation of a Substance resembling Artificial Tannin from Coal. By William Skey. Chem. News, I4, 206.

Ueber die Gerbsäure der Eichenrinde. Von A. Grabowski. Jour. prak. Chem., I02, 62 (abstr.).

Untersuchung der Bestandtheile der Tormentillwurzel. Von O. Rembold. Jour. prak. Chem., I02, 62 (abstr.). 
Ueber einige Gerbsäuren. Von H. Hlasiwetz. Annalen, r42, 219 ; Jour. prak. Chem., ror, 97. Im Auszug. a. d. Sitzber. der K. Akad. der Wiss. zu Wien.

Ueber die Bestandtheile des Thees. Von H. Hlasiwctz. Jour. prak. Chem., ror, 109.

Chinagerbsäure. Von O. Rembold. Annalen, I43, 270 ; Jour. prak. Chem., I03, 217 (1868).

Ratanhiagerbsäure. Von A. Grabowski. Annalen, r43, 274; Jour. prak. Chem., ro3, 219 (1868).

Filixgerbsäure. Von G. Malin. Annalen, 143, 276 ; Jourr. prak. Chem., I03, 221 (1868).

Filixsäure. Von A. Grabowski. Annalen, r43, 279 ; Jour. prak. Chem., I03, 225 (1868).

Gerbsäure der Granatwurzelrinde. Von O. Rem. bold. Annalen, 143, 285 ; Jour. prak. Chem., ro3, 229 (1868).

Ueber Aesculus Hippocastanum. Von Dr. Friedrich Rochleder. Jour. prak. Chem., ror, 415. A. d. Sitzber. der K. Akad. der Wiss. zu Wien.

Ueber die Umwandlung der Gallussäure in Gerbsäure. Von Julius Löwe. Jour. prak. Chem., ro2, 111.

Darstellung der Aepfelsäure aus den Fruchtzapfen von Rhus coriaria und das verschiedene Verhalten der Gerbsäuren. Von H. Reinsch. Archiv der Pharm., 182, 153; from N. Jahrb. für Pharm., 25, 2.

Ueber Galläpfel. Von Archer. Archiv der Pharm., I79, 120 .

A Critical Examination of the Various Published Processes for the Estimation of I'annin. By Mr. John Watts. Phar. Jour. Trans. [2], 8, 515.

Gerbstoff der Rhabarber (Rheumgerbsäure). Von Herrn Kubly. Phar. Zeit. Russ., 1867, 603 ; Zeit. für Chem. [2], 4, 308. 
Ueber die Beziehungen der Gerbsäuren, Glucoside, Phlobaphene und Harze. Von H. Hlasiwetz. Annalen, I43, 290; Jour. prak. Chem., I05, 360 (1868).

Ueber das gallussaure Silberoxyd. Von C. Barfoed. Jour. prak. Chem., ro2, 314.

Ergebnisse bei der Bestimmung der Gerbsäure in einer grösseren Anzahl von Eichenrinden mit Berücksichtigung der neueren Methoden. Von Prof. Dr. Büchner. Dingler, 184,250 and 330.

Studien über quantitative Bestimmungs-Methoden der Gerbsäuren. Von C. O. Cech. Inaug.-Diss., Heidelberg, 1867.

\section{5.}

Entsteht aus der Gerbsäure des Sumachs, Gallussäure und Pyro-Gallussäure oder nicht? Von Prof. Dr. Bolley. Jour. prak. Chem., 103, 485.

Ueber die Nadeln von Abies pectinata. Von Fr. Rochleder. Jour. prak. Chem., ro5, 123; from Sitzber. der K. Akad. der Wiss. zu Wien, Juli, 1868.

Zur Kenntniss der Korksubstanz. Von M. Siewart. Jour. prak. Chem., I04, 118.

Ueber die Kapseln der Rosskastanienfrüchte. Von Dr. Fr. Rochleder. Jour. prak. Chem., r 04, 392; "a. d. 57. Bde. Sitzber. der K. Akad. d. Wiss. zu Wien."

Ueber einige Bestandtheile der Blätter der Rosskastanie. Von Dr. Fr. Rochleder. Jour. prak. Chem., I04, 385 ; "a. d. 57. Bde. Sitzber. der K. Akad. d. Wiss. zu Wien."

Sur la formation d'acides gallique et pyrogallique au moyen du tannin de sumac. Par MM. Bolley et Rob. Baehr. Bull. Soc. Chim., Io, 67 ; from Schweiz. Zeit, 1868. 
Ueber einige Gerbsäuren. Von H. Hlasiwetz. Ueber die Gerbsäure der Eichenrinde. Von A. Grabowski. Ueber die Bestandtheile der Tormentill-IVurzel. Von O. Rembold. Annalen, 145, 1 and 5 ; Jour. prak. Chem., I05, 389 .

Ueber die Bildung von Ellagsäure aus Gallussäure. Von Dr. Julius Löwe. Jour. prak. Chem., I03, 464.

Ueber die verschiedenen Methoden zur quantitativen Bestimmung der Gerbsäure. Von C. D. Braun. Zeit. anal. Chem., 7, 130.

Zur Gerbsäurebestimmung. Von Th. Salzer. Zeit. anal. Chem., 7, 70.

Ueber einige Benzol-Derivate. Von Friedrich Rochleder. Jour. prak. Chem., ıo6, 293 (1869). "A. d. 58. Bde. d. Sitzber. d. K. Akad. d. Wiss. zu Wien."

\section{9.}

Ueber Catechin und Catechugerbstoff. Von Dr. Friedrich Rochleder. Jour. prak. Chem., Io6, 307. "A. d. 59. Bde. d. Sitzber. d. K. Akad. d. Wiss. zu Wien."

Ueber einige Bestandtheile der Blätter und Rinde von Cerasus acida. Von Dr. Friedrieh Rochleder. Jour. prak. Chem., ro7, 385. "A. d. 59. Bde. d. Sitzber. d. K. Akad. d. Wiss. zu Wien."

Ucber den Gerbstoff der Eiche. Von Dr. Theodor IIartig. Stuttgart, Verlag der J. G. Cotta'schen Buchhandlung. (A monograph of 40 pages.)

Ueber Tannin. Von Otto Facilides. Archiv der Pharm., r89, 234.

Ueber die Bedeutung der Gerbstoffe im Pflanzenreich (eine phytochemische Abbandlung). Von Theophil Schmieden. Neues Rep. für Pharm., 18, 257 and 321 ; Pharm. Zeit. Russ., 1869. 
Quantitative Determination of the Amount of Tannin in Various Vegetable Astringents. By Henry K. Bowman. Am. Jour. Phar., 1869, 193.

Die Gerbrinde. Von J. G. Neubrand. J. D. Sauerländer's Verlag, Frankfurt a. M., 1869. (A monograph of 231 pages.)

On a Comparative Analysis of English and Aleppo Galls. By John Barrow. Chem. News, I9, 169.

\section{0.}

Ueber die Darstellung des Tannins. Von Oscar Rothe. Archiv der Pharm., r92, 232.

Sur la composition de la peau, sur les modifications que le tannage lui fait subir, et sur la fermentation du tannin dans les fosses. Par M. A. Müntz. Ann. Chim. Phys. [4], 20, 309.

Ueber den farbigen Gerbstoff des Erlenholzes (den Erlenfarbstoff). Von Dr. F. Dreykorn und Prof. Dr. E. Reichardt. Dingler, r95, 157; Archiv der Pharm. [2], $142,215$.

Beurtheilung der analytischen Methoden, welche zur Bestimmung des in Katechu, Ratanhia, Kino und einigen anderen gebräuchliehen Droguen vorhandenen Gerbstoffs zur Verfügung stehen. Von Günther. Pharm. Zeit. Russ., 1870 ; Chem. Central. [3], 2, 395 ; Zeit: anal. Chem., ro, 354.

Ueber den Gerbstoff der Eiche. Von A. Wolf. Inaugural-Disscrtation, Lcipzig, 1870.

\section{1.}

Recherches sur la formation de l'acide gallique. Par M. Sace. Compt.-Rend., 72, 766.

Beiträge zur Kenntniss der im Sumach, in den Myrobalanen und in der Dividivi vorkommenden Gerbsäuren. Von N. Günther. Inaugural-Dissertation, Dorpat, 1871. 
Ueber das Verhalten von Stärke und Dextrin gegen Jod und Gerbsäure. Von Victor Gricssmayer. Annalen, I60, 40.

Ueber Natur und Constitution der Gerbsäure. Von Hugo Schiff. Berichte, 4, 231; Bull. Soc. Chim., 18, 23.

Ueber Gerbsäure und einige Derivate derselben. Von Hugo Schiff. Berichte, 4, 967.

Ueber die quantitative Bestimmung des Gerbstoffgehalts der Eichenrinde. Von C. Neubauer. Zeit. anal. Chem., ro, 1.

1872.

Ueber reine Galläpfelgerbsäure. Von Julius Löwe. Zeit. anal. Chem., II, 365.

Bucharische Galläpfel. Von R. Palm. Archiv der Pharm., I99, 233.

Sur la purification du tannin. Par M. Heinz. Jour. Phar. Chim. [4], 15, 308.

Dyes and Dye-Stuffs. By Dr. Crace Calvert. Phar. Jour. Trans. [3], 2, 596 and 614.

"Derivate." Von Hugo Schiff. Berichte, 5, 291, 437 , and 642.

Synthese geschwefelter Gerbsäuren. Von Hugo Schiff. Berichte, 5, 661 and 731.

Neue Reaction auf Alkalien und vice versa auf Gerbsäurc. Von Victor Griessmayer. Zeit. anal. Chem., I I, 43.

Beiträge zur Technologie der Gerbstoffe. Von Prof. Dr. Rud. Wagner. Dingler, 205, 137. From Deutsche Industriezcitung, 1872, Nr. 10 und 11.

\section{3.}

Tannic Acid, its Determination, and the Percentage found in some Woods of the Southwest. By Wm. MeMurtrie. Ann. Rep. of the U. S. Commissioner of Agriculture, 1873, 181. 
Das Tannin. Von Dr. C. M. Kurtz. Zeit. des Oesterreich. Apotheker-Vereines, II, 56.

Beziehung zwischen Catechusäure und Catechugerbsäure. Von Julins Löwe. Zeit. anal. Chem., 12, 285.

Estimation of Tannin. By J. M. Merrick. Am. Chemist, 3, 322, and 4, 15 and 202.

Untersuchungen über die Natur und Constitution der Gerbsäurc. Von Hugo Schiff. Annalen, I70, 43 ; Gazz. di Chim., 3, 353, and 4, 540.

Geschwefelte Gerbsäure aus Phloroglucin. Von Hugo Schiff. Berichte, 6, 26.

Ueber Sumachgerbsäure. Von Julins Löwc. Zeit. anal. Chem., 12, 128.

Ucber das Vorkommen des Quercetins und Qucrcitrins im Catechu und Sumach. Von Julius Löwe. Zeit. anal. Chem., I2, 127.

Die Schälung von Eichenrinden. Von W. Wohmann, C. Neubauer und C. A. Lotichius. Wiesbaden, C. W. Kreidel's Verlag, 1.873.

\section{4.}

Methode zur Tanninbestimmung mittelst Quccksilbernitrat. Von J. Macagno. Berichte, 7, 360.

Eine Methode zur direkten Bestimmung des Weinfarbstoffs. Von E. Grassi. Berichte, 7, 359.

Dosage du tannin, de l'acide gallique et de l'acide pyrogalliquc. Par M. Maurice Prud'homme. Bull. Soc. Chim., 2r, 169.

Nouvel appareil pour doser les tannins contcnus dans les diverses matières astringentes employées dans la tannerie. Par M. A. Terreil. Jour. Phar. Chim. [4], 19, 445 ; Bull. Soc. Chim., 2r, 261.

Coffee, Chicory, and Tea. By A.H. Allen. Chem. News, 29, 140, 167, 189, and 221. 
Dosage du Tannin. Par MM. A. Müntz et Ramspacher. Bull. Soc. Chim., 22, 241; Compt.-Rend., 79, 380 ; Jour. Phar. Chim. [4], 20, 287 ; Zeit. anal. Chem., I3, 462 .

On the Estimation of Tannic Acid. By C. Estcourt. Chem. News, 29, 109.

Preliminary Notice on the Action of Bromine on Protocatechuic Acid, Gallic Acid, and Tannin. By J. Stenhouse. Chem. News, 29, 95.

Gerbsaures Eiscnoxydul zur Injection von Holz. Von A. Hatzfeld. Berichte, 7, 262.

Bestimmung der Gerbsäure. Von Pavesi und Rotondi. Berichte, 7, 590.

Procédé de dosage comparatif des substances tannants. Par E. Schmidt. Bull. Soc. Chim., 21, 256 ; Zeit. anal. Chem., r4, 204.

Sul compostamento dell' acido tanniconella strato coltivabile. Di M. Mercadante. Gazz. di Chim., 4, 484.

The Estimation of Tannin. By C. Estcourt. Chem. News, 3o, 63.

The Estimation of Tannin. By H. R. Procter. Chem. Ncws, зо, 78 .

Reaction für Gerbsäure. Von H. R. Procter. Berichte, 7, 598; Zeit. anal. Chem., I3, 326.

Zur Albuminometrie und zur Kenntniss der Tanninverbindungen der Albuminate. Von L. Girgensohn. Neues Rep. für Pharmaeie, 22, 557; Zcit. anal. Chem., 13, 78 .

Catechusäurc und Catechugerbsäure. Von Julius Löwe. Zeit. anal. Chemie, 13, 113.

Observations et expériences pharmacologiques sur le tannate de quinine. Par M. Jules Regnauld. Jour. Phar. Chim. [4], 19, 5. 
1875.

Die physiologische Wirkung der Gerbsäure in der Pflanze. Von J. Sehel. Bot. Jahrb., 1875, 872.

Action of Bromine on Protocatechuie Acid, Gallie Acid, and Tannin. By J. Stenhouse. Jour. Chem. Soc., 28,9 .

Estimation of Tannic Acid. By S. J. Simplkin. Chem. News, 32, 11.

On a Simple Apparatus for the Estimation of Tannie Acid by the Method of Müntz and Ramspacher. By William Thompson. Chem. News, 32, 310.

Zur Bestimmung des Gerbstoffs. Von E. Grassi. Berichte, 8, 257.

Sur un procédé pour déterminer le tannin dans les vins, et sur les stations expérimentales en Italie. Par E.-J. Maumené. Bull, Soe. Chim., 22, 41.

Ueber die Natur und Constitution der Gerbsäure. Von Hugo Schiff. Annalen, I75, 165; Jour. Chem. Soe., 28, 1197.

Synthese gesehwefelter Gerbsäuren. Von Hugo Sehiff. Annalen, I78, 171; Gazz. di Chim., 6, 1.

Nuovo metodo per dosare l'acido tannico eontenuto nei vini. Di Antonio Carpenè. Gazz. di Chim., 5, 129 ; Berichte, 8, 822.

Ueber die Gerbsäure der Dividivi-Sehoten und deren Beziehung zur Gallussäure. Von Julius Löwe. Zeit. anal. Chem., r4, 35.

Ueber die Gerbsäure der Myrobalanen und ihre Identität mit der Ellagengerbsäure. Von Julius Löwe. Zeit. anal. Chem., r4, 44.

Ueber die Gerbsäure der Knoppern und ihre Identität mit Gallusgerbsäure. Von Julius Löwe. Zeit. anal. Chem., I4, 46. 
Ueber die Gerbsäure der Eiche. Von J. Oser. Chem. Central., 1875, ว̌17; Wien. Anz., 1875, 139.

Beiträge zur Chemie der Eichen-, Weiden und Ulmenrinde. Von Edwin Johanson. Inaugural-Dissertation, Dorpat, 1875. Druek von C. Mattieson.

\section{6.}

On the Estimation of Tannin by Müntz and Ramspacher's Method. By Henry R. Procter. Chem. News, 33, 245.

An Investigation of Methods of Determining the Tannin of Tea. By J. S. Clark. Am. Jour. Phar., $1876,558$.

Ueber die Anwendung des Tannins bei der Wasseranalyse. Von Hermann Kaemmerer. Jour. prak. Chem., I22, 322.

Note sur un nouveau procédé de titrage des matières astringentes. Par.M. Ferdinand Jean. Bull. Soc. Chim., 25, 511. Berichte, 9, 730.

Ueber die Gerbsäure aus den Hopfenzapfen. Von Carl Etti. Annalen, I80, 223.

Tanninbestimmung. Von J. Barbieri. Berichte, 9, 78. American Tanning Materials. By Wm. McMurtrie. Ann. Rep. of U. S. Commissioner of Agriculture, 1876, 52.

\section{7.}

Sur les catéchines. Note de M. Arm. Gautier. Compt.Rend., 85, 342 and 752 .

Préparation et essai du tannate de quinine. Par M. Stocder. Jour. Phar. Chim. [4], 26, 418.

Sur la préparation du tannate neutre de quinine. Par M. P. J. Hooxman. Jour. Phar. Chim. [4], 25, 420.

Sur la fixation du tannin par les tissus végétaux. Par. M. Müntz. Jour. Phar. Chim. [4], 26, 339 ; Compt.Rend., 84, 955. 
On Scientific Research in Relation to Tanning. By Henry R. Procter. Chem. News, 36, 137.

Contribuzione allo studio del tannino contenuto nell' Ilex Paraguayensís. Di Pietro N. Arata. Gazz. di Chim., 7, 520. From "Anales de la Sociedad Científica Argentina."

The Relation of Tannin and Gallic Acid. By Thomas Christy. Jour. Soc. Arts, 25, 456.

Sur l'œnotannin ou tannin du vin. Par M. A. Gautier. Bull. Soc. Chim., 27, 496; Berichte, ro, 1179.

Note sur le quebracho, nouvelle matière tannifère. Par M. Ferdinand Jean. Bull. Soc. Chim., 28, 6.

Des bois tannants et en particulier du Quebracho aspidosperma; application du même bois à la teinture. Par M. J. Arnaudon. Bull. Soc. Chim., 28, 524.

On Some Methods of Estimating Tannins. By Henry R. Procter. Chem. News, 36, 58; Phar. Jour. Trans. [3], 7, 1020 .

Some Constituents of Hops. By Emery G. Bissell. A.m. Jour. Phar., 49, 582.

Economic Value of Sumac. Ann. Rep. of U. S. Commissioner of Agriculture, 1877, 13.

American Sumac. By Wm. McMurtrie. Ann. Rep. of U. S. Commissioner of Agriculture, 1877, 76.

Sumac. Ann. Rep. of U. S. Commissioner of Agriculture, $1877,546$.

Dyeing and Tanning Materials. Ann. Rep. of U. S. Commissioner of Agriculture, 1877, 144.

On the Tannic Acid of Guarana. By Francis V. Green, M.D. Am. Jour. Phar., 49, 388.

Ueber die Bestimmung des Gerbstoffs. Von J. I Iöwenthal. Zeit. anal. Chem., I6, 33 and 201. 


\section{8.}

Beitrag zur Kenntniss einiger Gerbstoff bestimmungsmethoden. Von Franz Kathreiner. Dinglcr, 227, 481, and 228, 53.

Ueber die Bestimmung des Gerbstoffs und die Analyse des Thees. Von Dr. Josef Maria Eder. Dingler, 229, 81.

Tanninbestimmung in der Eichenrinde. Von E. Perret. Dingler, 229, 400. From Moniteur Industriel Belge, Jan., 1878.

Ueber das Quebrachoholz. Von Dr. Josef Moeller. Dingler, 230, 481. From Deutsche Industriezeitung, 1878,45 .

Sur les catéchines; catéchines des gambirs. Par M. Arm. Gautier. Compt.-Rend., 86, 668.

Zur Kenntniss einzelner chemischer Bcstandtheile der Weiden und deren pathologischen Gebilde und über einige Reactionen mit Gerbstoffen und denen verwandten Körpern. Von Edwin Johanson. Archiv der Pharm., 213, 103.

On the Estimation of Tannins. By H. R. Procter. Chem. News, 37, 256.

The Estimation of Tannins. By C. Estcourt. Chem. News, 38, 58.

Notes on Antimony Tannate. By Ellen S. Richards and Alice W. Palmer. Am. Jour. Sci. and Arts [3], I6, 196 and 361.

Tanning Materials of South America. By Professor Max Siewart. Jour. Soc. Arts, 26, 143.

Extracts of Tannin. Chem. News, 37, 265 ; Moniteur Scientifique, May, 1878.

Sulla preparazione dell' acido digallico. Del Dr. Pasquale Freda. Gazz. di Chim., 8, 363. 
Ricerche e considerazioni sulla natura glucosidica del tannino naturale delle noci di galla; (1), e su di una sostanza cristallizzata obtenuta mercè l'azione dell' acido ar'senico sull' acido gallico. Del Dr. Pasquale Freda. Gazz. di Chim., 8, 365; Berichte, II, 1248.

Notiz über einige griechische Gerbmaterialien. Von Hans Jahn. Berichte, II, 2107.

Gährung von Glycose in Gerbsäurelösung. Von P. Freda und H. Schitf. Berichte, II, 346 and 2033.

Gerbstoff bestimmung. Von Herrn Katbreiner. Dingler, 228, 53; Berichte, II, 981 and 1137.

Gerbstoff bestimmung. Von Herrn Eder. Zeit. anal. Chem., I9, 106 ; Berichte, II, 1932.

Wattle Bark. Ann. Rep. of U. S. Commissioner of Agriculture, 1878, 507.

Improvements in the Manufacture of Materials containing Tannic Acid. By F. G. Vedova. English Patent, No. 2948, July 24, 1878.

Notes on the Tannins. By B. H. Paul and C. 'I'. Kingzett. Jour. Chem. Soc., 33, 217.

Notes on an Abnormal Specimen of Glycerinum Acidi Tannici. By Georgc Masson. Phar. Jour. Trans. [3], 9, 201.

A Method of Distinguishing Gallic, Tannic, and Pyrogallic Acids. By William Watson. Phar. Jour. Trans. $[3], 9,46$.

Tanning Material. Ann. Rep. of U. S. Commissioner of Agriculture, 1878, 93.

Examinations for Tannic Acid-Analysis of Canaigre Root. By Peter Collier. Ann. Rep. of U. S. Commissioner of Agriculture, 1878, 119.

Examinations of Docks for Tannin. By Peter Collier. Ann. Rep. of U. S. Commissioner of Agriculture, $1878,121$. 
Examination of Algarobilla for Tannin. By Peter Collier. Ann. Rep. of U. S. Commissioner of Agriculture, 1878, 121.

1879.

Gerb- und Farbmaterialien. Von Dr. Josef Moeller. Dingler, 232, 275, 373, and 478. "Vom Verfasser gef. eingesendeter Auszug aus dem Berichte über die Weltaustellung in Paris, 1878."

Ucber das Quebrachoholz. Von Dr. Josef Moeller. Dingler, 23I, 451.

Gerbstoffexcurse. Von W. Eitner. Der Gerber, 5, 197.

Bestimmung des Gerbstoffs und die Analyse des Thees. Von Josef Maria Eder. Dingler, 230, 81.

Chinesische Gallen. Von Carl Hartwich. Archiv der Pharm., 214, 524.

Gambir. Von Carl Hartwich. Archiv der Pharm., $2 \times 4,527$.

Le tannin de l'algarobillo. Par M. R. Godeffroy. Jour. Pharm. Chim. [4], 30, 71. From "Zeit. des Oesterreich. Apotheker-Vereines," March, 1879.

Osservazioni varie intorno all'acido digallico. Del Prof. Ugo Schiff. Gazz. di Chim., 9, 1; Berichte, r2, 33.

Volumctric Estimation of Sulphuric Acid, Tannin, etc. By Arthur G. Haddock. Chem. News, 39, 156.

Sul pretesco acido tannico artificiale. Del Dr. Pasquale Freda. Gazz. di Chim., 9, 327.

Zur Constitution der Ellagsäure. Von Hugo Schiff. Bcrichte, 12, 1533.

Beitrag zur Kenntniss einiger Gerbstoff-Bestimmungsmethoden. Von Franz Kathreiner. Dingler, 227, 481; Zcit. anal. Chem., 18,"112. 


\section{0.}

Rhatania-tannic acid. Von Herrn Raabe. Phar. Zeit. Russ., 1880, 577.

Ueber dic Gerbsäure der Eichenrinde. Von C. Etti. Monatshefte, I. 262.

Die Gerberinden. Ein monographischer Beitrag zur technischen Rohstofflehre. Von Dr. Franz R. v. Höhnel. Berlin, Verlag von Robert Oppenheim.

Ueber Algarobilla. Von C. Hartwich. Archiv der Pharm., 21 7, 281.

On the Tannic Acid of Sumach Leaves. By J. Macagno. Chem. News, 4r, 63; Gazz. di Chim., Ix, 297.

Materials containing Tannin used in Japan. By I. Ishikawa. Chem. News, 42, 274.

The Chemistry of Tanning. By Edward Davies. Phar. Jour. Trans. [3], ro, 536.

On the Action of Light and Darkness on Standard Ammonium Chloride and Tannin Solutions. By A. R. Leeds. Jour. Am. Chem. Soc., 2, 246.

Ueber Phlobaphen, Eichenroth und Lohgerberei. Von Dr. Carl Böttinger. Annalen, 202, 269.

The Estimation of Tannin. By Peter Collier. Ann. Rep. of U. S. Commissioner of Agriculture, 1880, 142.

\section{1.}

Ueber den Zucker der Eichenrindgerbsäure. Von C. Böttingcr. Berichte, I4, 2390 ; Dingler, 24I, 69.

Ucber die Gerbsäure der Eichenrinde. Von Dr. Julius Löwe. Zeit. anal. Chem., 20, 208.

Ueber die Bestimmung des Gerbstoffs. Von A. Lehman. Phar. Zeit. Russ., 1881, 321; Jour. Phar. Chim. $[5], 4,351$. 
Verfahren der Gerbsäure-Extract-Gewinnung mittels Dialyse. Von Otto Kohlrausch. Dingler, 240, 72 (abstract from Patent).

Verfahren zur Extraction des Tannins. Von P. Gondolo. Dingler, 240, 472 (abstract from Patent).

Ricerche sul tannino contenuto negli organi del Corbezzolo, (Arbutus unedo.) Di S. de Luca. Gazz. di Chim., II, 487.

Estimation of Tannin in Tea. By Alfred Hill, M.D. Analyst, 6, 95 and 232.

Sur la déperdition en tannin des substances tannantes. Par MM. Müntz et Schoen. Jour. Pharm. Chim. [5], 4, 583.

Sur le dosage du tannin. Par. M. Riche. Jour. Pharm. Chim. [5], 3, 230.

Zur Gerbstoff bestimmung. Von Edwin Johanson. Phar. Zeit. Russ., 1881, 577.

Beiträge zur Kenntniss des Catechins. Von C. Etti. Monatshefte, 2, 547.

Sur le dosage du tannin. Par A. Remont. Jour. Pharm. Chim. [5], 3, 230.

On the Estimation of Tannic Acid in Tanning Materials. By Nelson H. Darton. Jour. Am. Chem. Soc., 4,4 .

On the Comparative Value of the Several Methods of Determining Tannic Acid. By Nelson H. Darton. Jour. Am. Chem. Soc., 4, 49 and 62.

Studio chimico della Persea lingue e del suo tannino. Di Dr. Pietro N. Arata. Gazz. di Chim., I r, 245. From "Anales de la Sociedad Científica Argentina," ro, 193.

\section{2.}

New Commercial Plants and Drugs-No. 5. Tanning Materials. By Thomas Christy. Published by Christy and Co., London, 1882. 
Zur Gerbstoff bestimmung nach Löwenthal. Von Ferd. Simand. Dingler, 244, 391.

Zur Bestimmung des Gerbstoffs. Von A. Lehman. Zeit. anal. Chem., 21, 414. From Phar. Zeit. Russ., $1882,321$.

Zur Gerbstoff bestimmung. Von Ferd. Simand. Dingler, 246, 41 and 133.

Ueber Algarobilla für Gerbereizwecke. Von W. Eitner. Dingler, 244, 80.

On the Application of Tannin. By Juste Koechlin. Chem. News, 45, 112.

Zur Ermittelung der Gerbsäure in Gerbmaterialien, Lohbrühen und Gerbstoffabfällen. Von A. Gawalovski. Zeit. anal. Chem., 21, 552.

Das Neubauer'sche Verhältniss der reducirenden Wirkung von Oxalsäure und Tannin. Von C. Couneler und J. Schröder. Berichte, I5, 1373.

Emploi du tannin dans l'analyse des eaux. Par M. A. Jorissen. Jour. Phar. Chim. [5], 6, 289.

Origin of Tannips. By C. F. Cross and E. J. Bevan. Jour. Chem. Soc., 4I, 106.

Ueber die Bestandtheile der Blätter von Fraxinus excelsior L. Von Dr. Wilh. Gintl und Friedr. Reinitzer. Monatshefte, 3,745 .

Sur le titrage du tannin et de l'acide œnogallique dans les vins. Par M. F. Jean. Compt.-Rend., 94, 733; Bull. Soc. Chim., 38, 358.

\section{3.}

Zur Geschichte der Eichenrindegerbsäuren. Von C. Böttinger. Berichte, I6, 2710.

Zur Untersuchung der Gerbstoffextracte. Von F. Simand. Der Gerber, 9, 211; Dingler, 251, 471 (1884). 
Uebersicht der technisch und pharmaceutisch verwendeten Gallen. Von C. Hartwich. Archiv der Pharm., 221, 819 and 881.

Zur Gerbstoff bestimmung. Von Edwin Johanson. Phar. Zeit. Russ., 22, 577 ; Zcit, anal. Chem., 23, 428.

The Estimation of Tannin. By M. Roquès. Phar. Jour. Trans. [3], 14, 163. From L'Union Pharm., 24, 359.

Zur Geschichte der Eichenrindegerbsäuren. Von C. Etti. Monatshefte, 4, 512.

\section{4.}

Tannin Values in the Bark of various Trees of the United States. By S. P. Sharples. Tenth U.S. Census, 9, 265.

Vergleichende Untersuchungen über die Gerbstoffe der Nymphaea alba und odora, Nuphar luteum und advena, Cosalpinia coriari, Terminalia Chebula und Punica granatum. Von Alexander Fridolin. Phar. Zeit. Russ., 1884, 393; Berichte, Ref. 17, 487.

Werthbestimmung der Eichenrinde und der Galläpfel. Von Franz Musset. Pharm., Central., 25, 179 and 191; Chem. News, 5r, 41.

Knoppern. Von W. Eitner. Der Gerber, 10, 269; Dingler, 255, 485 and 487.

Ucber verschiedene Gerberrinden. Von C. Councler. Gerberzeitung, 1884, 275 and 297 ; Dingler, 255, 483.

Eichenholzextract. Von W. Eitner. Der Gerber, ro, 256 .

Extractgehalt verschiedener Gerbmittel. Von F. Simand. Der Gerber, 10, $5 \pm$ and 173; Dingler, 255, 487.

Verhalten der Gerbstoffbrühen beim Kochen. Vo॥ M. Riegel. Der Gerber, ro, 102; Dingler, 255, 488. 
Ueber den Gerbstoff der Castanea vesca. Von Paul Nass. Inaugural Dissertation, Dorpat, 1884. Abstract in Zeit. anal. Chem., 25, 134.

Dosage du tannin contenu dans les matières végétales, et principalement dans les écorces de chêne, bouleau, sapin, quebracho, quinquinas, dividivi, guttes, ctc. Par M. Perret. Bull. Soc. Chim., 4I, 22.

Note sur l'action de l'air sur les dissolutions de tannin et sur le dosage des tannins. Par M. Antony Guyard. Bull. Soc. Chim., 4I, 336; Chem. News, 5o, 26.

Tea Analysis. By J. F. Geisler. Analyst, 9, 220 ; from American Grocer.

Zur Kenntniss der Gerbsäuren. Von O. Nasse. Berichte, I7, 1166.

Observations au sujet du dosage du tannin. Par P. Carles. Jour. Phar. Chim. [5], 9, 33.

Sur le tannin de l'écorce d'aune. Par M. Lamasse. Jour. Phar. Chim. [5], 9, 485.

Estimation of Tannic Acid by Carbonate of Lead. By Robert Jackson. Chem. News, 50, 179.

Function of Tannin in Vegetable Cells. By W. Gardiner. Phar. Jour. Trans. [3], 14, 588; Jour. Chem. Soc. Abstracts, 46, 1209 ; from Proc. Cambridge Phil. Soc.

Nuovo processo tannimetrico. Del Prof. Adolfo Casali. Annali di Chimica, 79, 65.

Ueber das Verhalten von Tannin und Eichenrindegerbsäure gegen verschiedene Reagenzien. Von C. Etti. Berichte, I7, 1820.

Zur Kenntniss der Hemlockgerbsäure. Von C. Böttinger. Berichte, I 7, 1041.

Ueber Rindengerbsäuren. Von C. Böttinger. Berichte, I7, 1123. 
Erfahrungen über die Acetylirung der Gallussäure, des Tannins und deren Anwendung. Von C. Böttinger. Berichte, I 7, 1503.

Eine mikrochemische Reaktion auf Gerbstoff. Von J. W. Moll. Berichte, I8, 84 (Ref.). "Aus Maandbl. v. Naturw.," Nov., 1884.

Verfahren zum Reinigen vom Gerbstofflösungen. Von J. Doutreleau und Comp. German Patent 32,632, Oct., 1884.

Ueber das Verhalten der Gerbsäure bei der Keimung der Pflanzen. Von Dr. Rulf. Inaugural-Dissertation, Halle, 1884.

\section{5.}

Verhalten Fehling'scher Lösung gegen Tannin. Von A. Sonnenschein. Dingler, 256, 555; Berichte, 18, 649 (Ref.).

Die Untersuchung gebrauchter Lohe. Von Franz Musset. Phar. Central., 26, 44.

Physiologische Bedeutung des Gerbstoffs in Pflanzen. Von M. Westermaier. Sitzber. der W. Akad. zu Berlin, 1885, 1115 ; Jour. Phar. Chim. [5], 18, 15.

Catechu and its Uses for Dyeing and Printing. By Dr. D. . Jour. Soc. Dyers and Col., I, 94 ; from Centralblatt für die Text. Ind., 3, 55.

Bestimmung der freien Säuren in Gerbebrühen. Von B. Kohnstein und F. Simand. Dingler, 256, 38.

Commercial Tannin. By T. Mabern. Phar. Jour. Trans. [3], 15, 850.

The Gambier and Baros Camphor of Johore. By Peter Macewan. Phar. Jour. Trans. [3], 15, 793.

The Quantitative Determination of Tannin. By Dr. F. Becker. Chem. News, 51, 229. 
Prep. und Anwendung des Catechus als Beize. Von E. Ziegler. Jahresbericht, 1885, 2256 ; Patent-from Moniteur Scientifique [3], I5, 1250.

Verfahren zur Gewinnung von Gerbstoffextract. German Patent 32,693; Dingler, 258, 180.

Extraction du tannin du bois de chêne. Par M. Henry. Revue Scientifique, 36, 96.

Note sur un nouveau mode d'essai des matières tannifères. Par M. Ferdinand Jean. Bull. Soc. Chim., 44, 183.

Hop Extract. By Wayne B. Bissell. Am. Jour. Phar., 1885, 166.

Zur Gerbstoff bestimmung nach der Löwenthal'schen Methode. Von R. Ulbricht. Berichtc, I8, 1116.

Extractionsapparat für Gerbmittel und Farbhölzer. Patent of F. A. W. Bense. Dingler, 256, 275.

Note sur les tannates de mercure. Par M. Charles Casthelaz. Jour. Phar. Chim. [5], 12, 353.

Note sur un nouveau procédé de dosage volumétrique du tannin. Par E. Durien. Jour. Phar. Chim. [5], I $2,374$.

Preliminary Notc on the Synthesis of Tannin. By Bertram Hunt. Chem. News, 52, 49.

Bericht über die Verhandlung der Commission zu1 Feststellung einer einheitlichen Methode der Gerbstoffbestimmung; geführt am 10 Nov., 1883, zu Berlin. Verlag von 'Theodor Fischer, Cassel, 1885. Zeit. anal. Chem., 25, 121 (1886).

Ueber die Gerbholzextractfabrik in Zupanje. Der Gerber, II, 205; Dingler, 259, 571.

On the Estimation of Tannin. By Bertram Hunt. Jour. Soc. Chem. Ind., 4, 263.

Note on the Destruction of Tannin by Boiling Solutions of Gambicr. By Bertram Hunt. Jour. Soc. Chem. Ind., 4, 266. 


\section{6.}

Untersuchungen der Gerbsäuren der Cortex adstringens Brasiliensis und Siliqua Bablah. Von V. Willuszewitcz. Phar. Zeit. Russ., 25, 1, 17, and 33; Berichte, 19, 349 (Ref.).

Neue Gerbstoff bestimmungsmethode. Von Hermann Dieudonné. Chem. Zeit., 70, 1076; Berichte, 19, 715 (Ref.).

Unterscheidung des Kastanienholzextract vom Eichenholzextract. Von Wilhelm Eitner und Johannes Meerkatz. Phar. Centralh., 27, 25; Der Gerber, II, 193.

Gerbstoffbestimmung. Von E. Breutel. Zeit. für die Chemische Industrie, I, 64.

New Test for Tannic Acid. By J. E. Saul. Phar. Jour. Trans. [3], 17, 387 .

Nouvelle réaction du tannin. Par. J. W. Moll. Jour. Phar. Chim. [5], 14, 559.

New Tanning Materials. Phar. Jour. Trans. [3], I7, 85.

Zur Gerbstoff bestimmung, ein Vorschlag. Von E. B. Zeit. anal. Chem., 25, 527; Chem. News, 55, 236.

Algarobilla, ein natürlicher gelber Farbstoff. Von G. H. Hurst. Dingler, 262, 288; abstract from Romen's Jour., 1886, 205.

Uebcr Untersuchung von Gerbstoffen. Von F. Nötzli. Dingler, 259, 177, 228, and 272.

Zur Untersuchung von Gerbstoffextracten. Von F. Simand und B. Weiss. Der Gerber, 12, 1; Dingler, 260,564 .

Recent Contributions to the Estimation of Tannins. By Henry R. Proctcr. Jour. Soc. Chem. Ind., 5, 79 and 210. 
Darstellung eines Farbstoffes und eines Gerbmittels aus Katechu. Von E. Ziegler. Dingler, 262, 35 ; German Patent, No. 36,472.

\section{7.}

Tannin: its Present and Future Sources. By-Henry Trimble. Jour. Franklin Institute [3], 93, 442.

Animal Tannin. By M. Villon. Chem. News, 56, 175.

On a Gravimetric Method of Estimating Tannins. By Henry R. Procter. Jour. Soc. Chem. Ind., 6, 94.

Die Gerb- und Farbstoff-Extracte. Von Dr. Stanislaus Mierzinski. A. Hartleben's Verlag, Wien, 1887.

Determination of Tannin in Sumach. By J. Maengno. Jour. Chem. Soc. Abstracts, 52, 624 ; Chem. Central., 1887, 125.

On the Estimation of Tannins, with critical Notes on the Mothods of Hammer and Löwenthal. By Henry M. Rau. Jour. Am. Chem. Soc., 9, 52.

Nouveau procédé de dosage du tannin. Par M. Villon. Bull. Soc. Chim., 47, 97.

Sur un acide tannique contenu dans les baies de sorbier. Par MM. Camill Vincent et Delachanal. Bull. Suc. Chim., 47, 492.

Note on Estimation of Tannin in Extracts of Sumac. By T. Chalkley Palmer. Jour. Soc. Dyers and Col., 3, 175.

Analysis of some Tannin Matters. By P. Kay and E. Bastow. Jour. Soc. Dyers and Col., 3, 132.

Ueber Hemlockextract. Von F. Simand. Der Gerber, 13, 102 ; Zeit. Chem. Industrie, I, $35 \overline{7}$.

Isomeric dell' acido tannico. Di Ugo Sehiff. Gazz. di Chim., I7, 552 ; Berichte, 21, 524 (Ref.).

Ueber die Gerbsäure des Eichenholzes. Von Dr. Carl Böttinger. Annalen, 238, 366. 
Ueber Abkömmlinge der Eichenrindgerbsäure. Von Dr. Carl Böttinger. Annalen, 240, 330.

Gallusgerbsaur'cs Hydrochinin. Von O. Hesse. Annalen, 24r, 273.

Zur Bestimmung der freien Säure in Gerbbrühen auf titrimetrischem Wege. Von R. Koch. Dingler, 264, 395.

Gerbstoff bestimmung. Von V. Schröder. Gerberzeitung, 1887, Nr. 33; Zeit. angw. Chem., 1888, 216.

\section{8.}

Gewichtsanalytische Bestimmung der Säuren in Gerbbrühen. Von R. Koch. Dingler, 268, 329.

Selbstthätiger Extractionsapparat für Gerbmaterialien u. s. w. Von Dr. R. Koch. Dingler, 267, 513.

Zur Weiner gewichtsanalytischen Methode der Bestimmung des Gerbstoffes in concentrirter Lösung. Von Dr. R. Koch. Dingler, 268, 329.

Zur Simand-Kohnstein'schen Methode der Säurebestimmung in Gerbbrühen. Von Dr. R. Koch. Dingler, 269, 168.

Dosage du Tannin. Par M.M. Ch. Colin et L. Benoist. Moniteur Scientifique [4], I I, 364; Dingler, 269, 288; Chem. News, 57, 214.

Ucber Differenzen, welche bei Gorbstoff bestimmungen entstehen können durch wechselnde Ausscheidungen schwerlöslichen Gierbstoffs. Von V. Schröder. Dingler, 269, 38.

Notes on Gambier. Phar. Jour. Trans. [3], 18, 863. Reprint from "Tropical Agriculturist," Feb. 1, 1888.

Catechu and Gambier. By Henry Trimble. Proc. Am. Phar. Assoc., 36, 99; Am. Jour. Phar., 1888, 497.

Gerbstoff bestimmung. Von F. Simand. Der Gerber, I4, 65; Zeit. angw. Chem., 1888, 216. 
Gerbstoff bestimmung. Von C. Councler. Gerberzeitung, 1888, Nr. 14; Zeit. angw. Chem., 1888, 216.

Ueber das Vorkommen und die Verteilung des Gerb. stoffs bei den Crassulaceen. Von E. Wagner. Chem. Central. [3], 19, 449 (abstract).

Ueber den Gerbsäuregehalt des Sumachs des Kaukasus. Von A. Lidow. Jour. russ. phys.chem. Gesell., 1888 (1), 607; Berichte, 2I, 889 (Ref.).

Einwirkung von $\mathrm{HCl}$ auf Tannin. Von Wehmer und Tollens. Annalen, 243, 327.

Ueber Verbindungen von Leim mit Gerbsäure. Von Dr. Carl Böttinger. Annalen, 244, 227.

Einiges über Gallussäure und Tannin. Von Dr. Carl Böttinger. Annalen, 246, 124.

Zur Kritik der Koch'schen Säurebestimmungs-methode in Gerbbrühen durch Johann Meerkatz. Von Dr. R. Koch. Dingler, 267, 459.

Zur. Chemie der Gerbsäuren (1. Abhdlg.). Von C. Etti. Monatshefte, Io, 647 and 805.

Bemerkungen zur Physiologie des Gerbstoffes. Von Friedrich Reinitzer. Ber. deut. botan. Gesell., 7, 187 ; Chem. Central. [4], I, 292 ; Jour. Chem. Soc. Abstracts, 58, 186.

\section{9.}

Reserve Material, especially Tannin, contained in Evergreen Leaves. By E. Schulze. Jour. Chem. Soc. Abstraets, 57, 540.

Tannin, its Solubilities, etc. By B.S. Proctor. Pbar. Jour. Trans. [3], 20, 351.

Zur Bestimmung der Gerbenden Stoffe in sauren Brühen. Von J. Meerkatz. Der Gerber, I5, 73.

Canaigre. By Henry Trimble. Am. Jour. Phar., $1889,397$. 
Die Bestimmung des Gerbstoffs mit Chamäleon. Von F. Gantter. Zeit. angw. Chem., 1889, 577.

Ueber die Einwirkung von Luft und Wärme auf den Gerbstoff der Weidenrinde. Von Dr. W. Sonne und Fr. Kutscher. Zeit. angw. Chem., 1889, 508.

Ueber Benzoyltannin. Von Dr. Carl Böttinger. Annalen, 254, 369.

Grundlinien zu einer Physiologie des Gerbstoffs. Von Gregor Kraus. Leipzig, 1889. A monograph of 131 pages.

Acidum Tannicum. Drogisten-Zeitung, Wien, 1889, 496.

On the Tannin in Indian and Ceylon Teas. By David Hooper. Chem. News, 6o, 311.

On some New Tests for Tannic and Gallic Acids. By S. G. Rawson. Chem. News, 59, 52.

- Estimation of Tea Tannin. By John T. White. Chem. News, 59, 261.

Action du borax sur les phénols polyatomiques. Note de M. Aug. Lambert. Compt.-Rend., ro8, 1017.

1890.

Les tannoïdes, introduction critique à l'histoire physiologique des tannins et des princies immédiats végétaux qui leur sont chimiquement alliés. Par L. Braemer. Lagarde et Sebille, Toulouse, 1890. 150 pages.

Distinction entre les tannins à l'alcohol et les tannins à l'eau. Par Adrian. Bull. Soc. Chim. [3], I, 595.

Etudes sur les bois tannants. Par S.-S. Arnaudon. Moniteur Scientifique [4], 4, 915.

Fabrication des tannins décolorés. Par M. A. Villon. Bull. Soc. Chim. [3], 3, 785. 
Dosage volumétrique du tannin. Par E. Guenez. Compt.-Rend., I Iо, 532; Jour. Phar. Chim. [5], 21, 618.

Dosage volumétrique du tannin dans les vins. Par MM. L. Roos, Cusson et Giraud. Jour. Phar. Chim. [5], 2I, 59.

On the Amount of Tannin in Certain Australian Plants. By J. H. Maiden. Jour, Roy. Soc. New South Wales, vol. 2 I.

Function of Tannin in Plants. By M. Büsgen. Jour. Chem. Soc. Abstracts, 58, 819 ; Chem. Central., 1890, 397.

Gantter's Method of Estimating Tannin. By H. R. Procter. Jour. Soc. Chem. Ind., 9, 260.

Bestimmung des Gerbstoffs in Rinden. Von G. Meyer. Phar. Zeit. Russ., 29, 820.

Some American Galls. By Henry Trimble. Am. Jour. Phar., 1890, 563.

Colorimetric Method for Estimating Tannin in Barks. By Samuel J. Hinsdale. Am. Jour. Phar., 1890, 119 ; Chem. News, 63, 50.

Ueber eine neue Reaction des Tannins. Von Dr. Carl Böttinger. Annalen, 256, 341.

Die Darstellung der reiner Gallusgerbsäure. Von R. Gartenmeister. German Patent " 51,326, vom 23. Juni, 1889, kl. 12 ;" Berichte, 23, 368 (Ref.).

Sur un nouveau procédé de dosage du tannin par l'iode. Par M. A. Moullade. Jour. Phar. Chim. [5], 22, 153.

Zur Bestimmung der Gerbstoff im Thee. Von P. Maltschewsky. Phar. Zeit. Russ., 29, 427.

De l'emploi des tannins comme agents désincrustants dans les chaudières à vapeur. Par Léo Vignon. Bull. Soc. Chim. [3], 3, 410. 
Untersuchung von Canaigre, einer gerbstoff haltigen Pflanze. Von Dr. Sigmund Kapff. Färber-Zeitung, I, 313 and 335.

Prüfung der Gantter'sehen Gerbstoff bestimmungsmethode. Von Prof. Dr. v. Sehröder und Dr. J. Pässler. Dingler, 277, 361.

Zur Klärung und Entfärbung von Gerbstoffextracten. Von A. Fölsing. German Patent 53,398; Zeit. angw. Chem., 1890, 559.

\section{1.}

Ueber die Gerbstoffe der Algarobilla und der Myrobalanen. Von. Dr. Georg Zölffel. Arehiv der Pharm., 229, 123.

Canaigre, ein neues Gerbmaterial. Von W. Eitner. Der Gerber, I7, 109.

Die Beziehungen des Gerbstoffs zur Pflanzenchemie. Von Dr. Th. Waage. Phar. Centralh., 1891, 247.

Ueber Togotorinde. Von P. Siedler und Th. Waage. Beriehte der Phar. Gesell., I, 77.

Was sind Gerbstoffe? Von Th. Waage. Berichte der Phar. Gesell., I, 92.

Estimation of Tannin. By Henry R. Proeter. Chem. News, 64, 10.

A Note on Löwenthal's Method of Tannin Analysis. By R. L. Whitely and J. T. Wood.. Jour. Soc. Chem. Ind., ro, 523.

Beiträge zur Analyse des Zuckers und Tannins im Wein. Von Dr. J. H. Vogel. Zeit. angw. Chem., 1891, 44.

Ueber dio Veränderlichkeit des Gerbstoffgebaltes in einigen Gerbmaterialien. Von Dr. Rudolf Jahoda. Zeit. angw. Chem., 1891, 104. 
Die Untersuchung Chinesischen Thees. Von P. Dvorkovitch. Berichte, 24, 1945.

Anleitung zur Bestimmung des wirksamen Gerbstoffgehal tes in den Naturgerbstoffen. Von Carl Scherk, jun. A. Hartleben's Verlag. Wien, Pest, Leipzig, 1891.

Heuchera Americana. By Josiah C. Peacock. Am. Jour. Phar., 1891, 172.

Geranium Maculatum. By Henry Trimble and Josiah C. Peacock. Am. Jour. Phar., 1891, 265.

Über die Canaigrewurzel, ein neues Gerbmaterial, und über Gerbstoff bestimmung. Von Dr. A. Klinger und Dr. A. Bujard. Zeit. angw. Chem., 1891, 513.

Preliminary Note on the Technical Analysis of Gambier. By H. R. Procter. Jour. Soc. Chem. Ind., ro, 681. Ueber die Gerbsäure des Eichenholzes. Von Dr. Carl Böttinger. Annalen, 263, 109.

Ueber einige Abkömmlinge des Tannins. Von Dr. Carl Böttinger. Archiv der Pharm., 229, 439.

Ueber Myrobalanen. Von W. Eitner. Der Gerber, I 7,4 .

Transformation de l'acide gallique et du tannin en acide benzoique. Note de M. Ch. - Er. Guignet. Compt.-Rend., II3, 200.

Sur la fabrication du jus et des extraits tannifères. Par Ferdinand Jean. Moniteur Scientifiquc [4], 5, 913.

Ueber Gallen. Von C. Hartwich. Phar. Centralh., 32, 588.

Chestnut-Wood Tannin. By Henry Trimble. Jour. Franklin Institute [3], 102, 303. 
In addition to the foregoing list, the following works contain noteworthy eontributions to the subject of the tannins :

1807.

Chemisehes Wörterbuch. Von Martin Heinrich Klaproth und Friedrich Wolff. Zweiter Band.

\section{7.}

Lehrbuch der Chemic. Von J. Jacob Berzelius. Dritten Bandes, erste Abtheilung. Aus dem Swedischen übersetzt. Von F. Wöhler.

\section{3.}

Handbuch der Chemie. Von Justus Liebig. Zweite Abtheilung.

\section{5.}

Chemie der organisehen Verbindungen. Von Carl Löwig. Erster Band.

\section{2.}

Hand-Book of Chemistry. By Leopold Gmelin. Volume 15. Translated by Henry Watts.

1864.

A Dietionary of Chemistry. By Henry Watts.

\section{3.}

Die Rohstoffe des Pflanzenreiches. Von Julius Wiesner.

\section{8.}

The Organic Constituents of Plants and Vegetable Substances. By G. C. Wittstein. Translated from the German by Baron Fred. von Mueller. 
1882.

Die Pflanzenstoffe. Von Aug. Husemann, A. Hilger und Theod. Husemann.

Physiologische Chemie der Pflanzen. Von Ernst Ebermayer.

1884.

Plant Analysis. By G. Dragendorff. Translated from the German by Henry G. Greenish.

1885.

A Text-Book of Tanning. By Henry R. Procter.

1856.

The National Dispensatory. By Alfred Stillé and John M. Maisch. Fourth Edition.

\section{7.}

Organic Analysis. By Albert B. Prescott.

Handwörterbuch der Chemie. Von A. Ladenburg.

The Principles of Pharmacognosy. By Friedrich A. Flückiger and Alexander Tschirch. Translated from the Second German Edition by Frederick B. Power.

\section{8.}

The Dispensatory of the United States of America. By H. C. Wood, Joseph P. Remington, and Samuel P. Sadtler. Sixteenth Edition.

A Treatise on Chemistry. By H. E. Roscoc and C. Schorlemmer. Volume 3, Part 4.

1889.

Commercial Organic Analysis. By Alfred H. Allen. Volume 3, Part 1. 
1890.

Handbuch der organischen Chemic. Von F. Beilstein. Zweite Auflage, Dritter Band.

\section{1.}

Muspratt's theoretische, praktische und analytische Chemie. Von F. Stohmann und Bruno Kerl. Vierte Auflage, Dritter Band.

A Hand-Book of Industrial Organic Chemistry. By Samuel P. Sadtler. 


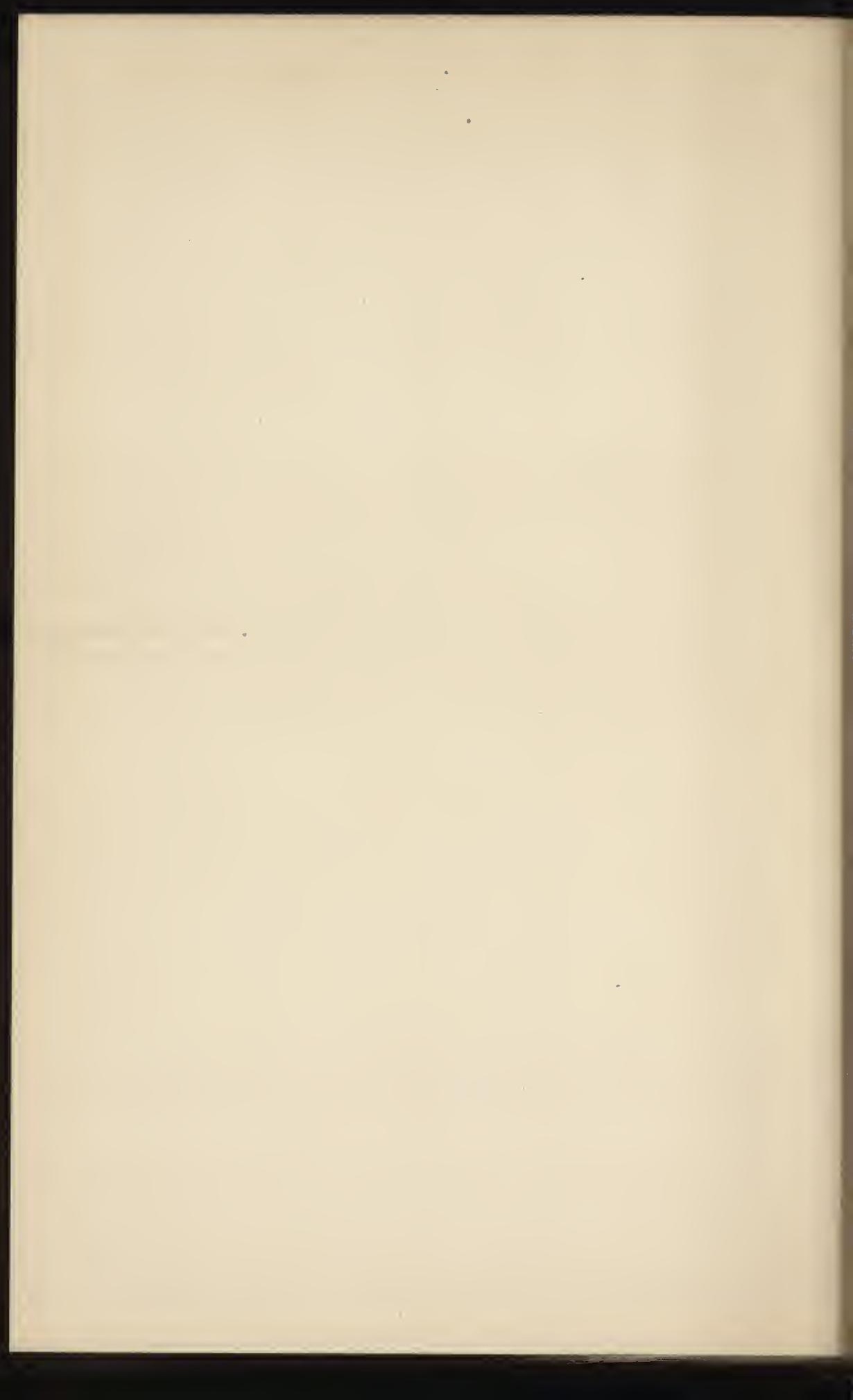




\section{N D EX.}

Acide tannique, 17.

Acorn-galls, 61 .

Acraspis erinacci, 63.

Alcohol-tannin, 81, 83.

Aleppo galls, 55, 58 .

American galls, 63 .

Aphis chinensis, 58.

Assay of tannin infusion, 48.

Bassorah galls, 60 .

Bloom, 24.

Bone tissue, 41.

Boric acid and tannin, 91 .

Burgundian galls, 62 .

Burmah galls, 60 .

Catechol, 24, 26.

Catechu, 25, 37.

Characters of the tannins, 17 .

Chestnut, 25.

Chinese galls, 58 .

Chinese pear galls, 60 .

Commission of technical chemists, 43.

Composition of tannic acid, 94 .

Constitution of tannic acid, 94 .

Crystal-tannin, 83 .

Cynips gallæ tinctoriæ, 55 .

Cynips isana, 60 .

Cynips Qucreus-calycis, 61.

Detcction of the tannins, 31 .

Digallic aeid, $76,77,94,96,97$, 98,99 .

Discovery of the tannins, 8 .

Dividivi, 37.

Eichen-Gerbstoff, 67.
Ellagic acid, 24, 27, 56 .

Estimation of the tannins, 31 .

Ether-tannin, 81.

Extracts, 22.

Gallotannic acid, 39, 53.

Galls, 24, 55 .

Galls, Aleppo, 55, 58.

American, 63.

Analyses of, 57, 58, 59, 60, 61.

Bassorah, 60 .

Burgundian, 62.

Burmah, 60 .

English, 58.

French, 62 .

German, 61.

Grcek, 62.

Hungarian, 62.

Istrian, 62 .

Italian, 62.

Japanese, 58 .

Levant, 55.

Mecca, 60.

Piedmontese, 61.

Pistacia, 62.

Tamarisk, 62 .

Turkish, 55 .

Gelatin methods, 32.

General characters, 17.

Gcranium maculatum, 18.

Gcrbsäure, 17.

Gerbstoff', 17.

German galls, 61 .

Greek galls, 62 . 
Heuchera Americana, 18.

Hide powder, 49.

Hide-powder methods, 32.

Holocarpis globulus, 63 .

Hungarian galls, 62 .

Hungarian larch, 31.

Indigo solution, 49.

Infusion, preparation of the, 44.

Iron-bluing tannins, 20 .

Iron-greening tannins, 20.

Istrian galls, 62 .

Italian galls, 62 .

Japanese galls, 58 .

Knoppern, 61.

Levant galls, 55 .

Mangrove, 25.

Mecea galls, 60 .

Metallic salts, precipitation by, 32.

Miscellaneous methods, 32 .

Nutgalls, 55.

Oak-bark, 37.

Pathological tannins, 21.

Pentacetyl-tannin, 87, 97.

Permanganate methods, 32 .

Permanganate solution, 48 .

Phlobaphenes, 24, 27.

Physiological tannins, 21.

Piedmontese galls, 61 .

Pistaeia galls, 62 .

Preparation of tannic acid, 78.

Properties of tannic acid, 88.

Purification of tannic acid, 78, 84.

Pyrogallol, 24, 26.
Quercitannic acid, 29.

Quercus alba, 63.

Austriaca, 62.

cerris, 62 .

ilex, 62 .

lobata, 63 .

lusitanica, 55 .

palustris, 63.

pedunculata, 61 .

robur, 61 .

sessiliflora, 61 .

tinctoria, 60 .

virens, 63.

Real's press, 46 .

Rhatany, 25.

Rhus glabra, 64 .

Japonica, 58.

Javanica, 58.

Rufigallic acid, 23.

Sampling, 44.

Schaum-tannin, 81 .

Sodom apple, 61 .

Sumac, 25, 37.

Tamarisk galls, 62 .

Tamarix articulata, 62 .

Gallica, 62.

Orientalis, 62 .

Tannates, 92.

Tannin, 17.

Tannin extracts, 22.

Tannin extracts, estimation of, 41.

Terebinthus, 62.

Turkish galls, 55 .

Valonia, 37.

Water-tannin, 81. 



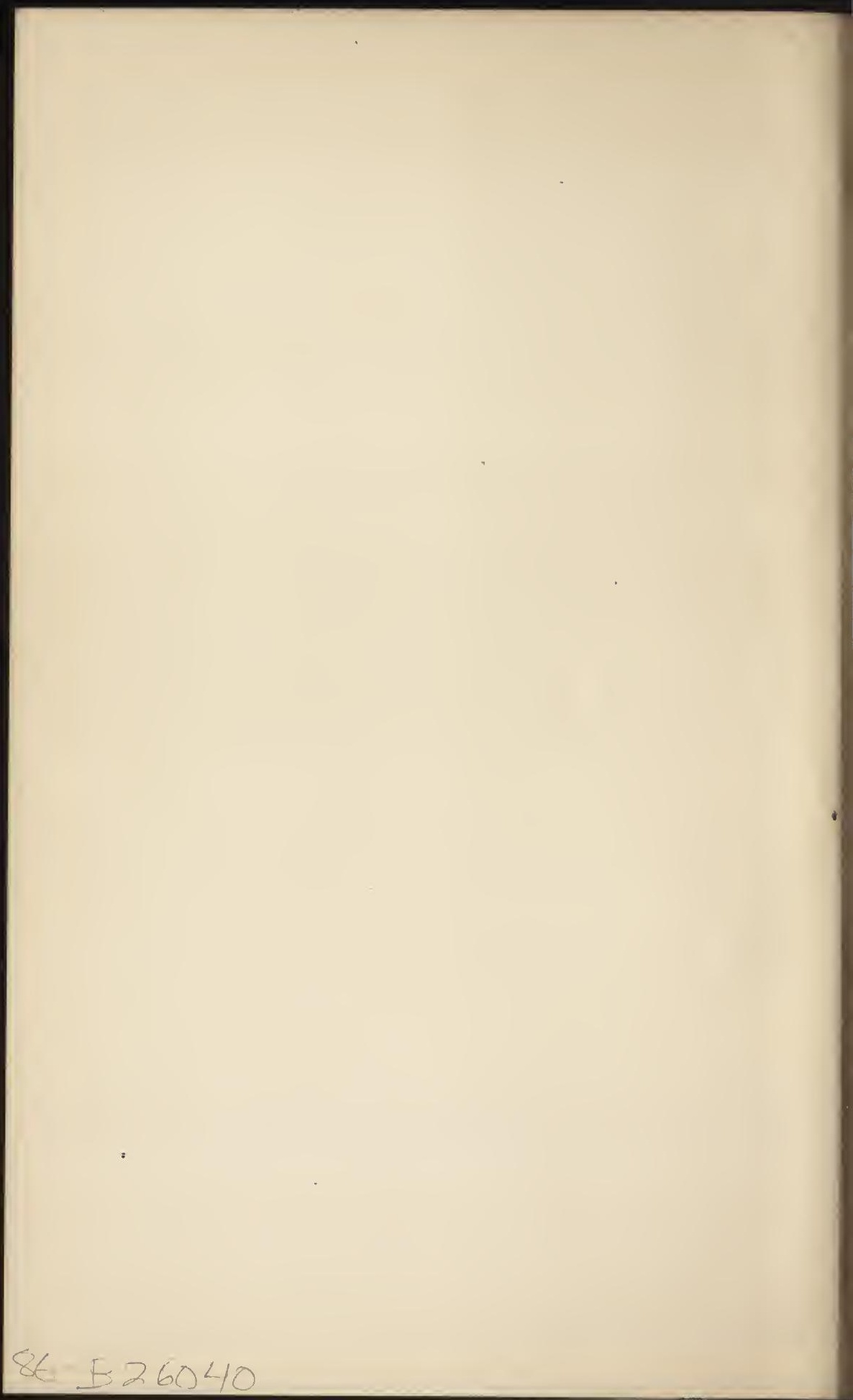


$\int$ 


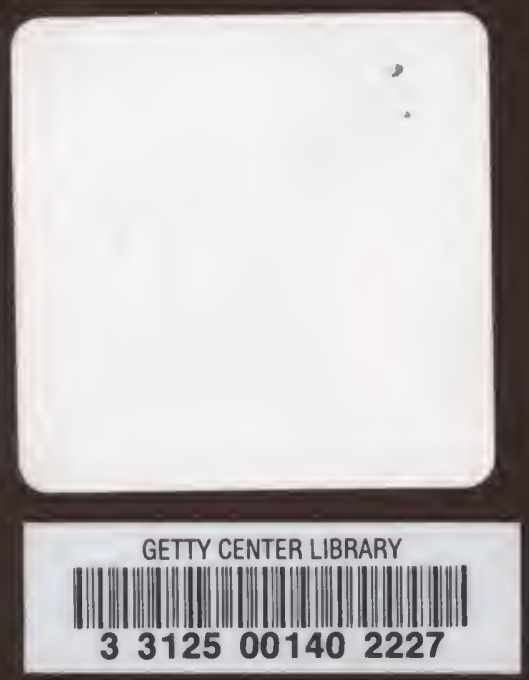


